\title{
Distribution of Lithostratigraphic Units Within the Central Block of Yucca Mountain, Nevada: A Three- Dimensional Computer-Based Model, Version YMP.R2.0
}

U.S. GEOLOGICAL SURVEY

Open-File Report 95-124

\author{
RECEIVED \\ SEP 191996 \\ OSTI
}

\section{PRDCESSED FROA BEST AVALLABLE COPY HHil}

Prepared in cooperation with the

NEVADA FIELD OFFICE,

U.S. DEPARTMENT OF ENERGY, under

Interagency Agreement DE-AI08-92NV10874

DISTRIBUTLN OF THIS DOCUMENT is UREMITET
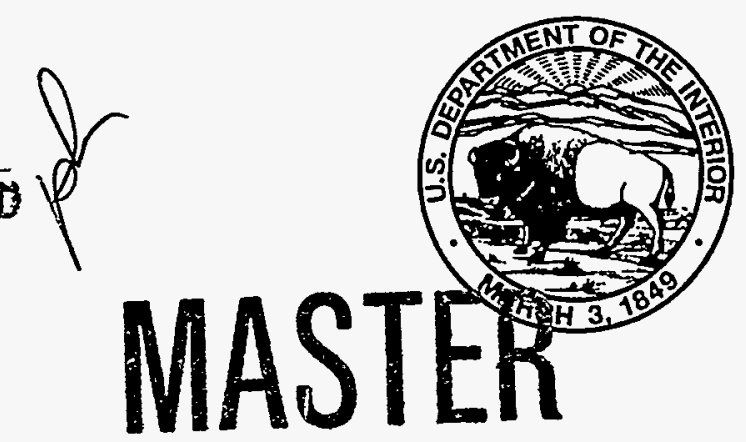


\section{DISCLAIMER}

Portions of this document may be illegible in electronic image products. Images are produced from the best available original document. 


\section{DISCLAIMER}

This report was prepared as an account of work sponsored by an agency of the United States Government. Neither the United States Government nor any agency thereof, nor any of their employees, makes any warranty, express or implied, or assumes any legal liability or responsibility for the accuracy, completeness, or usefulness of any information, apparatus, product, or process disclosed, or represents that its use would not infringe privately owned rights. Reference herein to any specific commercial product, process, or service by trade name, trademark, manufacturer, or otherwise does not necessarily constitute or imply its endorsement, recommendation, or favoring by the United States Government or any agency thereof. The views and opinions of authors expressed herein do not necessarily state or reflect those of the United States Government or any agency thereof. 


\section{Distribution of Lithostratigraphic Units Within the Central Block of Yucca Mountain, Nevada: A Three- Dimensional Computer-Based Model, Version YMP.R2.0}

By David C. Buesch, USGS, Las Vegas, NV; James E. Nelson, SAIC, Golden, CO; Robert P. Dickerson, SAIC, Golden, CO; Ronald M. Drake, II, SAIC, Golden, CO; Richard W. Spengler, USGS, Lakewood, CO; Jeffrey K. Geslin, SAIC, Las Vegas, NV; Thomas C. Moyer, SAIC, Las Vegas, NV; and Carma A. San Juan, SAIC, Golden, CO

\section{U.S. GEOLOGICAL SURVEY}

Open-File Report 95-124

Prepared in cooperation with the NEVADA FIELD OFFICE, U.S. DEPARTMENT OF ENERGY, under Interagency Agreement DE-Al08-92NV10874

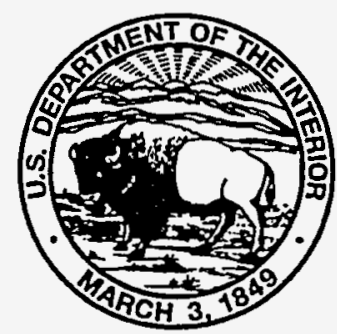




\section{U.S. DEPARTMENT OF THE INTERIOR \\ BRUCE BABBITT, Secretary}

\section{U.S. GEOLOGICAL SURVEY}

Gordon P. Eaton, Director

The use of firm, trade, and brand names in this report is for identification purposes only and does not constitute endorsement by the U.S. Geological Survey.

For additional information write to:

Chief, Hydrologic Investigations Program Yucca Mountain Project Branch

U.S. Geological Survey

Box 25046, Mail Stop 421

Denver Federal Center

Denver, CO 80225-0046
Copies of this report can be purchased from:

\section{U.S. Geological Survey}

Branch of Information Services

Box 25286

Denver, CO 80225-0286 


\section{CONTENTS}

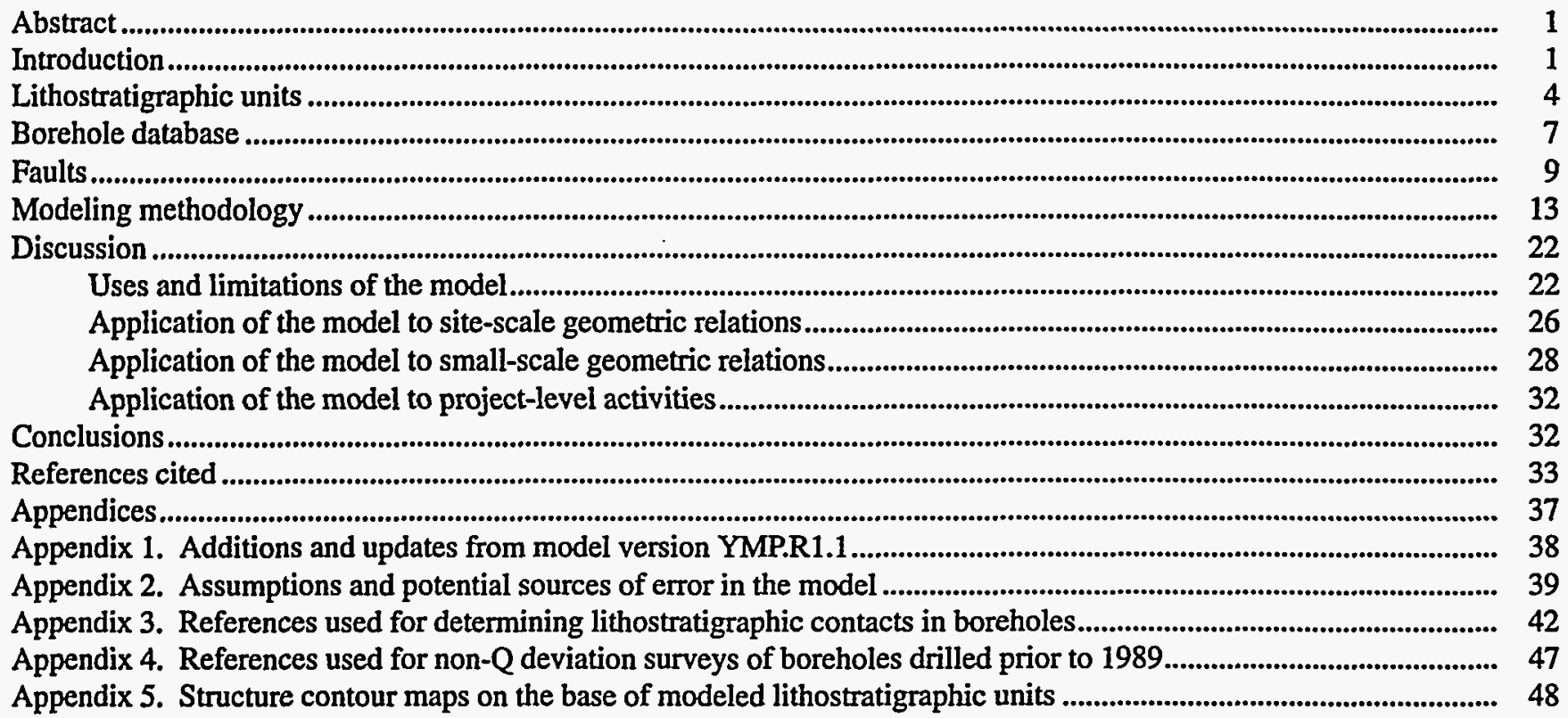

\section{FIGURES}

1. Map showing location of Yucca Mountain, Nevada, and the elements used in construction of model version YMP.R2.0

2. Map showing variations in vertical separation along the length of subblock-bounding faults ............................. 12

3a. Faults in the ancillary model with greater than 20 feet of vertical separation ....................................................... 14

3b. Faults in the ancillary model with 10 to 20 feet of vertical separation ....................................................................... 15

3c. Faults in the ancillary model with less than 10 feet of vertical separation................................................................ 16

4. General flow diagram of the modeling process (pre-Lynx)......................................................................................... 17

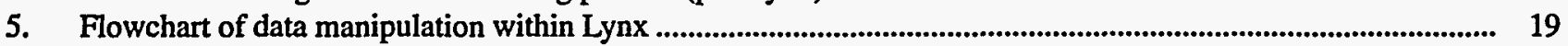

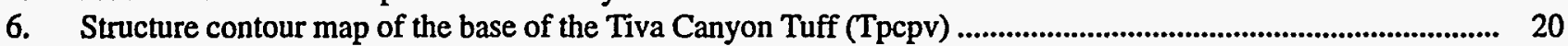

7. Triangulated surface of the base of Tiva Canyon Tuff structure contour combined with a triangulated map of the subblock-bounding faults.

8a. Structure contour map of the base of Pah Canyon Tuff (Tpp) in model subblock B ........................................... 23

8b. Isochore map of model unit Tptrv (surface i05) that includes pre-Pah Canyon Tuff bedded tuff and vitric nonwelded to moderately welded Topopah Spring Tuff

8c. Structure contour map of the base of model unit Tptrv in subblock B (surface B05) .......................................... 25

9. Structure contour map of three surfaces near boreholes UZ-N31 and UZ-N32 (A), and cross section through these boreholes (B)..

10. Vertically exaggerated fence diagram of thickness variations between boreholes UZ-N53, UZ-N54, and UZ-N55 (A), and structure contours of three surfaces near the boreholes (B). 


\section{TABLES}

1. Stratigraphic units, symbols, and color codes used in the model ............................................................................ 5

2. Correlation of lithostratigraphic, thermal-mechanical, and hydrogeologic units ...................................................... 6

3. Borehole locations from GENISES and Raytheon Services of Nevada .................................................................... 8

4. Designators of block- and subblock-bounding faults within Lynx .......................................................................... 9

5. Separation and dip data for faults with greater than 20 feet of vertical separation or strike-slip faults ..................... 10

6. Separation and dip data for faults with 10 to 20 feet of vertical separation............................................................... 11

7. Surface model file structure for fault subblocks $A$ to $G$................................................................................................ 18

8. Approximate changes in position of apparent synclinal axis, amount of change in strike of limbs, and width of area across which the change in strike occurs for various model units ......................................................... 27

\section{CONVERSION FACTORS AND VERTICAL DATUM}

$\begin{array}{lll}\text { Multiply By } & \text { By obtain }\end{array}$

$\begin{array}{rll}\text { foot (ft) } & 0.3048 & \text { meter (m) } \\ \text { inch (in) } & 0.254 & \text { millimeter }(\mathrm{mm}) \\ \text { inch (in) } & 2.54 & \text { centimeter }(\mathrm{cm}) \\ \text { mile (mi) } & 1.6093 & \text { kilometer }(\mathrm{km})\end{array}$

Sea level: In this report "sea level" refers to the National Geodetic Vertical Datum of 1929 (NGVD of 1929)_-a geodetic datum derived from a general adjustment of the first-order level nets of both the United States and Canada, formerly called Sea Level Datum of 1929. 


\section{Distribution of Lithostratigraphic Units Within the Central Block of Yucca Mountain, Nevada: A Three-Dimensional Computer-Based Model, Version YMP.R2.0}

By David C. Buesch, James E. Nelson, Robert P. Dickerson, Ronald M. Drake, II, Richard W. Spengler, Jeffrey K. Geslin, Thomas C. Moyer, andCarma A. San Juan

Abstract

Yucca Mountain, Nevada, which is being studied as a potential site for an underground highlevel radioactive waste repository, is underlain by 14.0 to $11.6 \mathrm{Ma}$ volcanic rocks tilted eastward $3^{\circ}$ to $20^{\circ}$ and cut by faults that were primarily active between 12.7 and $11.6 \mathrm{Ma}$. A threedimensional computer-based model of the central block of the mountain consists of seven structural subblocks composed of six formations and the interstratified-bedded tuffaceous deposits. Rocks from the $12.7 \mathrm{Ma}$ Tiva Canyon Tuff, which forms most of the exposed rocks on the mountain, to the 13.1 Ma Prow Pass Tuff are modeled with 13 surfaces. Modeled units represent single formations such as the Pah Canyon Tuff, grouped units such as the combination of the Yucca Mountain Tuff with the superjacent bedded tuff, and divisions of the Topopah Spring Tuff such as the crystal-poor vitrophyre interval. The model is based on data from 75 boreholes from which a structure contour map at the base of the Tiva Canyon Tuff and isochore maps for each unit are constructed to serve as primary input. Modeling consists of an iterative cycle that begins with the primary structurecontour map from which isochore values of the subjacent model unit are subtracted to produce the structure contour map on the base of the unit. This new structure contour map forms the input for another cycle of isochore subtraction to produce the next structure contour map. In this method of solids modeling, the model units are represented by surfaces (structure contour maps), and all surfaces are stored in the model. Surfaces can be converted to form volumes of model units with additional effort. Seven subblock-bounding faults have modeled separation, whereas other faults that do not have modeled separation are displayed in an ancillary model of fault geometry. The amount of dip-slip separation on modeled subblockbounding faults is assumed constant along the dip, but the amount can vary along the strike. The model is a compilation of data in a geometrically consistent three-dimensional framework that provides a useful site-scale lithostratigraphic and structural representation of the central block of Yucca Mountain. This lithostratigraphic and structural model can be used for (1) storing data from, and planning future, site characterization activities, (2) preliminary geometry of units for design of Exploratory Studies Facility and potential repository, and (3) performance assessment evaluations.

\section{INTRODUCTION}

Yucca Mountain, Nevada, is being investigated by the Department of Energy (DOE) as a potential site for a high-level radioactive waste repository (fig. 1). Many of the site characterization investigations, performance assessment evaluations, and engineering designs are based on the geologic framework of Yucca Mountain. Site characterization studies require information on the distribution and characteristics of lithostratigraphy and structure to establish data baselines and the locations of test areas. Performance of the site is directly related to thermal, mechanical, hydrologic, and geochemical properties that are commonly related to the lithostratigraphic framework. Engineering designs for the Exploratory Studies Facility (ESF) and the potential repository need geologic information along tunnel alignments for layout of ramps and drifts and calculation of storage requirements. Therefore, under- 


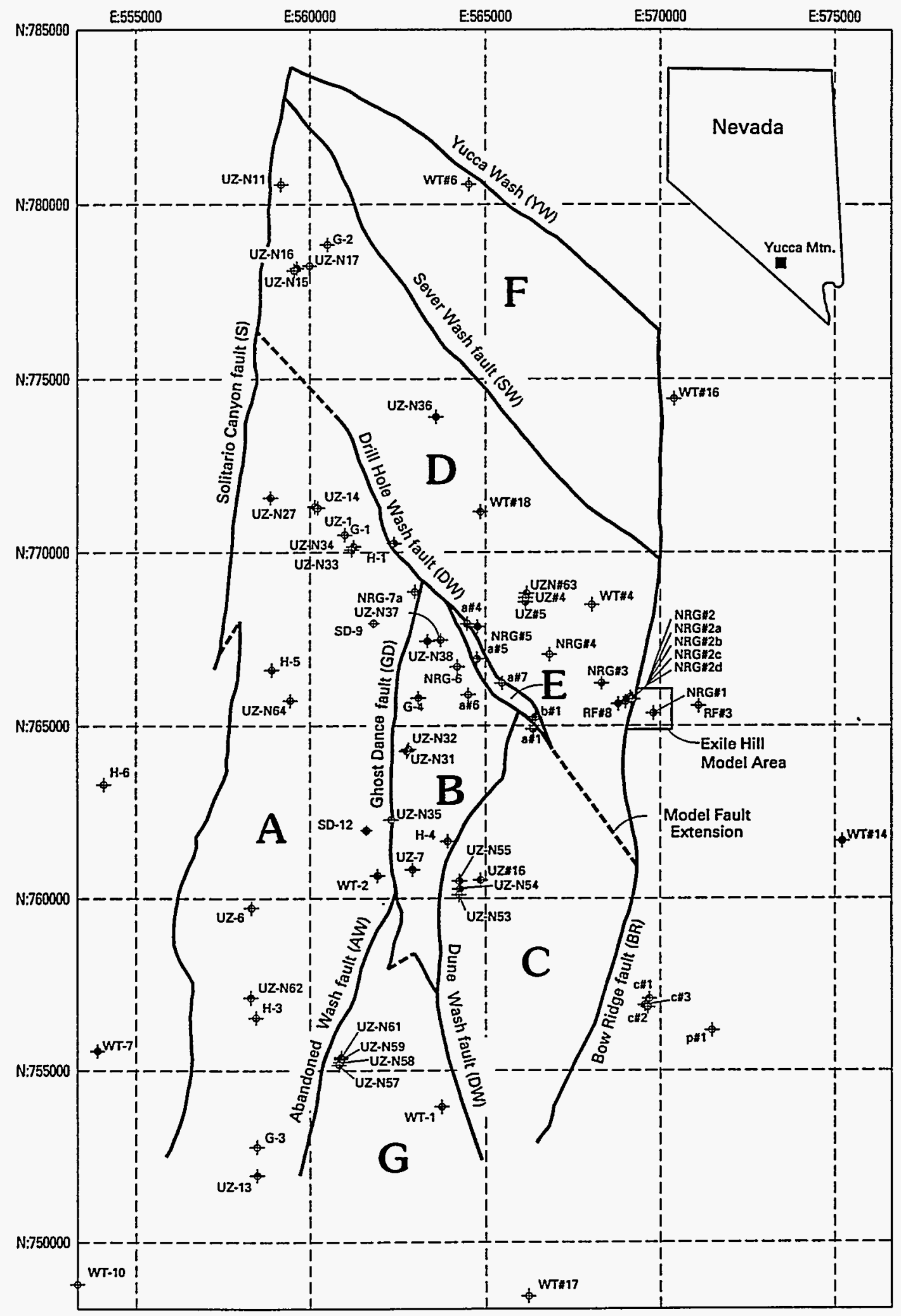

Figure 1. Map showing location of Yucca Mountain, Nevada, and the elements used in construction of model version YMP.R2.0. Elements include boreholes (circles and crosses), major faults used as subblock-bounding structures (solid lines), and subblocks $A$ to $G$. Dashed extensions of faults are inserted to enclose subblocks for modeling purposes only. Fault designators (in parenthesis) are used in figures $3 a$ and $3 b$. Fault traces are surface and subsurface expressions of the faults at 4,000 tt elevation. 
standing the geometry and spatial distribution (vertical and lateral distribution) of lithostratigraphic units and faults is crucial to assessing the suitability of the site and as input to geostatistical models of physical properties.

The local stratigraphic and structural framework for Yucca Mountain is fairly well understood, but several different volcanic and tectonic models exist for the region near Yucca Mountain (Scott and Bonk, 1984; Spengler and Fox, 1989; Carr, 1990; Scott, 1990; Fridrich and others, 1994; and Sawyer and others, 1994). Yucca Mountain consists of interstratified small-to-large-volume welded pyroclastic flow deposits, variable amounts of small-volume nonwelded pyroclastic flow and fallout deposits, localized lava flows, and minor amounts of redeposited material (Byers and others, 1976a and b; Christiansen and others, 1977; Scott and Bonk, 1984; Spengler and Fox, 1989; Sawyer and others, 1994; Buesch and others, 1996; and Moyer and Geslin, 1995). Rocks at Yucca Mountain were deposited between 14.0 and 11.6 Ma (Sawyer and others, 1994). Most of the rocks exposed at the surface of Yucca Mountain are in the 12.8 to $12.7 \mathrm{Ma}$ Paintbrush Group that includes the Tiva Canyon, Yucca Mountain, Pah Canyon, and Topopah Spring Tuffs and interstratified bedded tuffs. The $12.9 \mathrm{Ma}$ Calico Hills Formation and post-13.1 Ma Prow Pass Tuff (Hudson and Sawyer, 1994; and Sawyer and others, 1994) are exposed at the north and south ends of Yucca Mountain and occur in boreholes across the mountain (Broxton and others, 1993; and Moyer and Geslin, 1995). The remainder of the Miocene and Paleozoic lithostratigraphic section at Yucca Mountain is accessible only in boreholes.

This report describes the data and methodology used to construct a digital model of the lithostratigraphy of a portion of Yucca Mountain (fig. 1). Surface and subsurface lithostratigraphic data that define the geometry and spatial distribution of lithostratigraphic units on Yucca Mountain were assembled in ARC/INFO Geographic Information System, AutoCAD, or generated by hand, and then integrated into a digital model using Lynx Geosystems modeling software (Version 1.09). Lithostratigraphic contacts and faults are portrayed in the model as surfaces that can be viewed from any orientation. These surfaces, which are represented by structure contour maps for each modeled unit, are stored in the model. The Lynx model titled "Distribution of lithostratigraphic units within the central block of Yucca Mountain, Nevada, version YMP.R2.0, Rock Characteristics section, USGS, January, 1995, Milestone 3GGU510M" is contained on a TAR (Tape ARchive) tape ${ }^{1}$.
The model described in this report is a site-scale lithostratigraphic model that encompasses about $12.9 \mathrm{mi}^{2}$ of the central block of Yucca Mountain and is based on an irregular distribution of boreholes across the mountain and uses the 1:12,000 scale geologic map of Scott and Bonk (1984) for structural data. The model provides a means for viewing the lithostratigraphic units and faults interactively in three dimensions, a capability that allows geologists to study areas of interest without having to engage in the timeconsuming process of generating cross sections by hand. The model is useful in isolating areas where the geology is poorly understood and can be instrumental in planning and coordinating surface and subsurface data-collection efforts. The lithostratigraphic model also provides the framework necessary for layout and design of the ESF and potential repository, hydrologic and pneumatic process modeling, and performance assessment. The model is designed to represent sitescale geometric relations, and use of the model for detailed analysis of small features should be approached with caution.

The boundaries of the model are Yucca Wash to the north and northeast, an east-west line through borehole USW G-3 to the south, the Bow Ridge fault to the east, and the Solitario Canyon fault to the west (fig. 1). These boundaries are the same as those of the site-scale unsaturated zone model of Wittwer and others (1992). The model includes eleven lithostratigraphic units of the Paintbrush Group between the topographic surface and the base of the Topopah Spring Tuff, one lithostratigraphic unit each for the Calico Hills Formation and Prow Pass Tuff, and eight faults that bound structural subblocks. An ancillary model of fault geometry shows faults in the central block of Yucca Mountain other than the subblock-bounding faults. Selection of these lithostratigraphic units and subblock-bounding faults were based on discussions with saturated- and unsaturated-zone modelers, performance-assessment modelers, and designers of the ESF and potential repository.

Lithostratigraphic modeling by the Rock Characteristics Group of the Yucca Mountain Project Branch of the USGS began in 1992 with the compiling and reviewing lithostratigraphic information from boreholes and the 1:12,000 scale map of Scott and Bonk (1984). A previous model (version YMP.R0, also referred to as the demonstration model) is based on cross sections and volume modeling, and was released

\footnotetext{
${ }^{1}$ For users that do not have the Lynx software, a 1.4 MB floppy disk with AutoCAD files of the structure contour maps for modeled stratigraphic units can be obtained from the central data base for the Yucca Mountain Project.
} 
in April 1993, (R. Spengler and others, written commun., 1993; see also Buesch and others, 1993a and 1993b). The cross section-based (volume) model has the advantage of representing detailed fault complexity; 20 faults are modeled, each with more than $20 \mathrm{ft}$ of vertical separation at the intersection of primary cross sections (Buesch and others, 1993a and 1993b).

A change from volume-based to surface-based modeling was initiated in 1993 and 1994 to expedite the updating procedure and facilitate the transfer of data between various models such as finite element and finite difference models and in particular the "Earth Vision" software used by DOE. The surface-based model discussed in this paper and on the associated tape (version YMP.R2.0) consists of seven modeled structural subblocks (labeled A through $G$ in fig. 1) with as many as 13 modeled lithostratigraphic units per subblock. YMP.R2.0 supersedes version YMP.R1.0 and YMP.R1.1. YMP.R1.0 was a trial model used to develop the methodology of modeling surfaces. YMP.R1.1 updated the borehole locations and expanded the number of boreholes in the model to 73 . YMP.R2.0 has several updates and additions to YMP.R1.1 (Appendix 1). YMP.R2.0 contains an updated borehole database with 75 boreholes, including boreholes USW SD-9 and USW SD-12 and revised stratigraphic data from boreholes UE-25 NRG\#4 and UE-25 NRG\#5, revised stratigraphic depth data from downhole deviation surveys, and stratigraphic data from all boreholes for additional units to those modeled in version YMP.R2.0. Surfaces have been adjusted to reflect the updated subsurface data. Two new surfaces are added to represent the Calico Hills Formation and Prow Pass Tuff. An area east of subblock D along the Bow Ridge fault in the vicinity of the north portal for the ESF has been modeled (fig. 1), and the geometry of the Bow Ridge fault modified. All fault planes in the ancillary model of fault geometry are clipped at the topographic surface. A few lithostratigraphic units remain combined into modeled units to eliminate modeling of units that are typically less than 10-ft thick and to represent thermal-mechanical units as requested by users of the model.

The process of modeling is based on many assumptions, and there are numerous sources for error. Assumptions used and sources of error in the assumptions and input data are presented throughout this paper and are summarized in Appendix 2. These caveats to the model are presented as qualitative limitations without attempting quantitative error analysis.

\section{LITHOSTRATIGRAPHIC UNITS}

Lithostratigraphic units modeled in YMP.R2.0 and the associated symbol, surface number, and color code (as used on the associated tape) are presented in table 1. General descriptions of the lithostratigraphic units are available in Scott and Bonk (1984), but the modeled units are based on the revised stratigraphic nomenclature developed by the USGS (Buesch and others, 1996; Moyer and Geslin, 1995).

The 13 modeled units represent either individual lithostratigraphic units or combinations of two or more lithostratigraphic units (table 1). Modeled units that represent single lithostratigraphic units include the preYucca Mountain Tuff bedded tuff, Pah Canyon Tuff, and Topopah Spring Tuff crystal-poor vitrophyre, Calico Hills Formation, and Prow Pass Tuff. Several modeled units are a combination of two or more lithostratigraphic units because (1) some lithostratigraphic units are thin or not laterally continuous, or (2) lithostratigraphic units are grouped as a single unit in the thermal-mechanical and hydrogeologic stratigraphic systems (Ortiz and others, 1985; Montazer and Wilson, 1984). All the devitrified lithostratigraphic units in the Tiva Canyon Tuff are included in the model Tiva Canyon Tuff undifferentiated unit (Tpcun). Nonwelded and moderately welded subzones of the vitric zones in the crystal-poor members of the Tiva Canyon and Topopah Spring Tuffs are combined into single model units at the base of the respective formations (Tpcpv and Tptpv1\&2). The pre-Tiva Canyon Tuff bedded tuff is combined with Yucca Mountain Tuff in the model Yucca Mountain Tuff unit (Tpy). Pre-Pah Canyon Tuff bedded tuff and the nonwelded and moderately welded subzones of the vitric zone in the Topopah Spring Tuff are combined for the model Topopah Spring Tuff vitric unit (Tptrv). The crystal-rich vitrophyre of the Topopah Spring Tuff, which is commonly less than 10 -ft thick, is combined with the devitrified, crystalrich nonlithophysal zone to form the model Topopah Spring Tuff crystal-rich nonlithophysal unit (Tptrn). The crystal-rich lithophysal and crystal-poor upper lithophysal zones of the Topopah Spring Tuff form the model Topopah Spring Tuff upper lithophysal unit (Tptpul). A combination of the crystal-poor middle nonlithophysal, lower lithophysal, and lower nonlithophysal zones form the model Topopah Spring Tuff lower nonlithophysal unit (Tptpln).

Contacts of lithostratigraphic units are primarily derived from lithologic borehole logs (Appendix 3). Lithologic borehole logs are developed from core, bit cuttings, video camera, and geophysical logs. A ranking of confidence in determining the position of lithologic contacts in borehole ranges from high to low 
Table 1. Stratigraphic units, symbols, and color codes used in the model

\begin{tabular}{|c|c|c|c|}
\hline Lithostratigraphic Unit 1 & Symbol $^{2}$ & Surface ${ }^{3}$ & Color ${ }^{4}$ \\
\hline Tiva Canyon Tuff; undifferentiated, devitrified & Tpcun & 11 & Aqua 14 \\
\hline Tiva Canyon Tuff; crystal-poor ${ }^{5}$, vitric, nonwelded & Tpcpv & 1 & Red 2 \\
\hline $\begin{array}{l}\text { Pre-Tiva Canyon Tuff bedded tuff } \\
\text { Yucca Mountain Tuff }\end{array}$ & $\begin{array}{l}\text { Tpbt4 } \\
\text { Tpy }\end{array}$ & 2 & Blue 6 \\
\hline Pre-Yucca Mountain bedded tuff & Tpbt3 & 3 & White 1 \\
\hline Pah Canyon Tuff & Tpp & 4 & Maroon 11 \\
\hline $\begin{array}{l}\text { Pre-Pah Canyon Tuff bedded tuff } \\
\text { Topopah Spring Tuff; crystal-rich, vitric, nonwelded } \\
\quad \text { to moderately welded }\end{array}$ & Tpbt2 & 5 & Yellow 3 \\
\hline $\begin{array}{l}\text { Topopah Spring Tuff; crystal-rich, devitrified, } \\
\text { nonlithophysal (includes vitrophyre) }\end{array}$ & Tptrn & 6 & Purple 7 \\
\hline $\begin{array}{l}\text { Topopah Spring Tuff; crystal-rich, lithophysal } \\
\text { Topopah Spring Tuff; crystal-poor, upper lithophysal }\end{array}$ & Tptpul & 7 & Pink 12 \\
\hline $\begin{array}{l}\text { Topopah Spring Tuff; crystal-poor, middle nonlithophysal } \\
\text { Topopah Spring Tuff; crystal-poor, lower lithophysal } \\
\text { Topopah Spring Tuff; crystal-poor, lower nonlithophysal }\end{array}$ & $\begin{array}{l}\text { Tptpmn } \\
\text { Tptpll } \\
\text { Tptpln }\end{array}$ & 8 & Cyan 5 \\
\hline $\begin{array}{l}\text { Topopah Spring Tuff; crystal-poor, vitric, densely welded } \\
\text { subzone (includes vitrophyre) }\end{array}$ & d & 9 & Coral 13 \\
\hline $\begin{array}{l}\text { Topopah Spring Tuff; crystal-poor, vitric, nonwelded } \\
\text { to moderately welded }\end{array}$ & Tptpv1\&2 & 10 & Green 4 \\
\hline Calico Hills Formation (includes bedded tuff at base) & Tac & 12 & Blue 6 \\
\hline Prow Pass Tuff (includes bedded tuff at base) & Tep & 13 & Red 2 \\
\hline $\begin{array}{l}\text { Only bold items are modeled in version YMP.R2.0; itali } \\
\text { bold unit. }\end{array}$ & icized items a & grouped $\mathrm{x}$ & h subjacent \\
\hline 2 Symbols are from Buesch and others (in press) and Moye & yer and Geslin & (1995). & \\
\hline $\begin{array}{l}3 \text { "Surface" refers to the order in which Lynx surfaces were } \\
\text { created and Tcp was the last. }\end{array}$ & created. Tpc & vas the & st surface \\
\hline 4 Number following "Color" refers to the color numbering s & system within & Lynx. & \\
\hline $\begin{array}{l}5 \text { "Crystal-poor" indicates less than } 5 \text { percent crystals and } \\
\text { percent crystals. }\end{array}$ & "crystal-rich" & indicates gr & ter than 10 \\
\hline
\end{tabular}


Table 2. Correlation of lithostratigraphic, thermal-mechanical, and hydrogeologic units

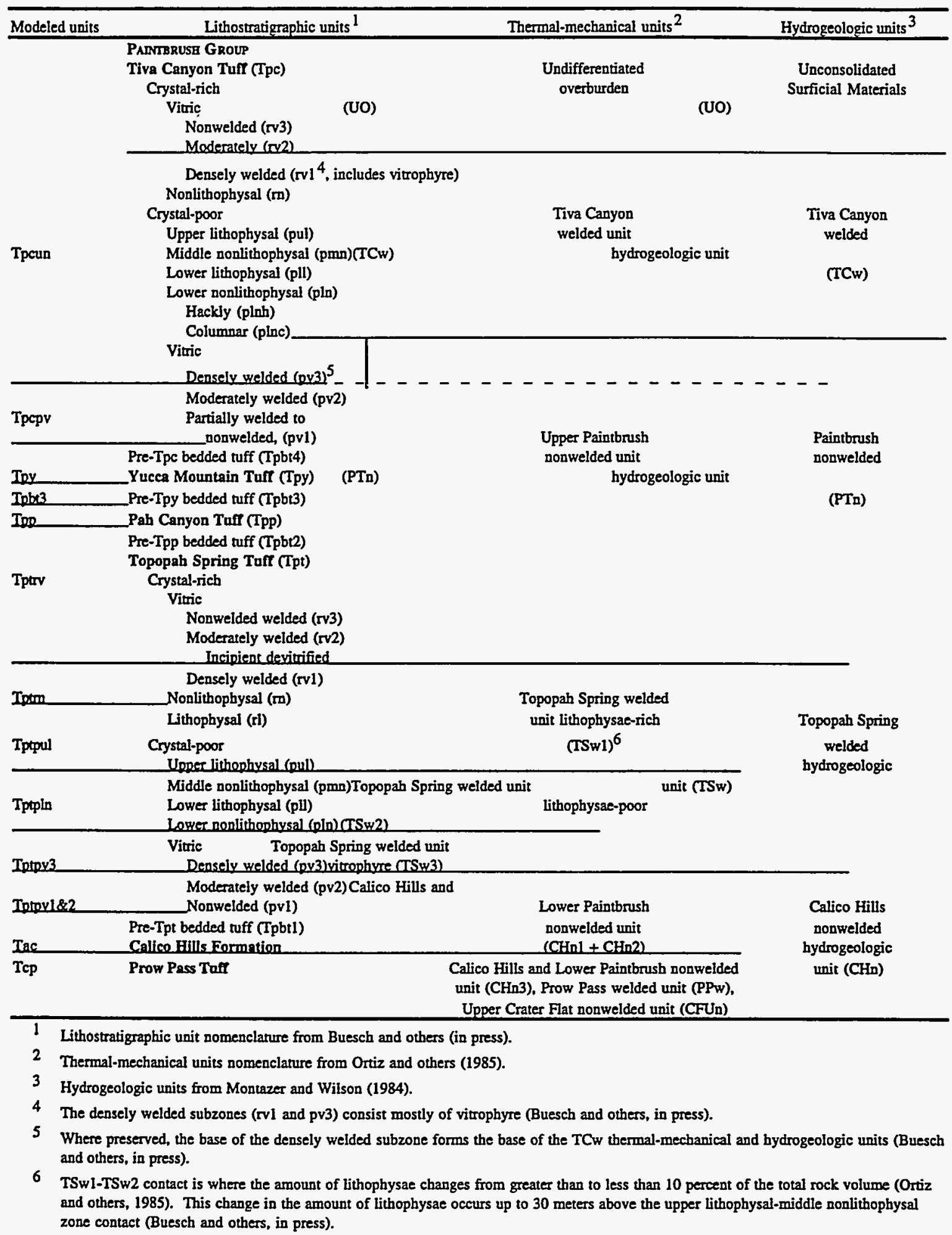


and is determined by the data used in the log: (1) Highest confidence for logs based on core, especially those supported by geophysical logs, (2) moderate confidence for logs based on cuttings in combination with video camera and geophysical logs, and (3) low confidence for logs based on cuttings only. Descriptions of the lithostratigraphic units and comparison with previously published reports are available in Buesch and others (1996) and Moyer and Geslin (1995). Distinguishing features used to identify contacts in the Paintbrush Group such as changes in clast types, occurrence of paleosols, and changes in the amount of minerals or lithophysae are described in Geslin and others (1995). Geophysical logs from six boreholes (UE-25 b\#1; UE-25 WT\#17; UE-25 WT\#18; USW UZ-1; USW H-1 and USW H-5; Nelson and others, 1991; Nelson, 1994) were used to determine lithostratigraphic contacts where core was not collected. Borehole core, bit cuttings, video camera, and geophysical logs provide data that is of variable quality or portrays different types of features in the rock and borehole walls. Mixing of these data can provide confirmation in a change in lithostratigraphic units, but the correlation between data sets are not always unique and can be a source of error in the model.

Distribution of the bedded tuff units Tpbt2, Tpbt3, and Tpbt4, and the interstratified Yucca Mountain and Pah Canyon Tuffs are determined on the basis of recently compiled lithologic logs from boreholes USW UZ-14, UE-25 UZ\#16, the NRG borehole series, and the UZ-N borehole series (Appendix 3). For con-

structing isochore maps ${ }^{2}$, thickness of the bedded tuff units in areas where Yucca Mountain or Pah Canyon Tuffs do not occur are calculated using the relative thicknesses of these individual bedded tuffs in boreholes UZ\#16, NRG-7/7A, and A\#6.

\section{BOREHOLE DATABASE}

The borehole database includes locations, elevations, total depth (TD), and accompanying lithostratigraphic units picked from 75 borehole logs. Borehole names and references for picks of lithostratigraphic contacts are in Appendix 3, and references for borehole deviation surveys are in Appendix 4. A Quality Assur-

\footnotetext{
${ }^{2}$ An isochore map shows drilled thickness of a stratigraphic unit, and the thickness is not corrected for dip of the unit, whereas an isopach map represents true thickness of stratigraphic unit (Bates and Jackson, 1987). Throughout most of the area near Yucca Mountain, the stratigraphic section dips about $5^{\circ}$ to $10^{\circ}$ and boreholes are not exactly vertical. Neither the local dip nor borehole deviation are well constrained in most areas. Thus, isochore maps are used in construction of the model.
}

ance (QA) program for the Yucca Mountain Project was implemented in 1989. Data collected under QA procedures are designated $Q$. Data collected since 1989 but not under QA procedures, or under a QA procedure but with non- $Q$ samples, are designated non- $Q$. Data collected prior to implementation of, or outside the QA program, are designated non-Q. Designation of $\mathrm{Q}$ or non-Q does not imply technical accuracy or integrity of the scientific product. Data sources and QA status include: (1) Recently drilled boreholes and logged core that are $Q,(2)$ re-logged non- $Q$ core and re-examination of non- $Q$ lithologic and geophysical logs, (3) published reports that are a mix of $Q$ and non- $Q$, and (4) nonpublished logs that were supporting data for published reports that are mostly non-Q.

The status of borehole locations is a mixture of $Q$ and non-Q data. The first boreholes drilled under the QA program were completed in 1992; therefore, the QA status and technical accuracy of most post-1991 borehole locations can be classified as $\mathrm{Q}$, but some are non-Q (written commun. from W. Kopatich to L. Hayes, June 17, 1994). Under the current guidelines of Raytheon Services of Nevada (RSN), a Q status is designated where survey data complies with four criteria: (1) Surveyed with calibrated instrument, (2) survey is tied to or can be traced back to Primary Control, (3) a survey closure was completed, and (4) the precision of closure is 1 in 5,000 or better (written commun. from W. Kopatich to L. Hayes, June 17, 1994). Of the 75 boreholes in the model, 4 have $Q$ status for proposed locations, 11 have $Q$ status for as-built locations, 27 have non- $Q$ status that might be upgraded to $Q$ upon completion of a historical review of the QA procedures in place at the time of the survey, and all 33 of the pre1992 boreholes have non- $Q$ status that can be upgraded to $Q$ by being re-surveyed (table 3 ). Resurveying of borehole positions with Global Positioning System methods has recently begun to rectify questions of position accuracy.

Borehole locations, elevations, total borehole depth, and QA status are summarized in table 3 and are from the Yucca Mountain Project database GENISES as directed by R. Nelson, Acting Project Manager (written commun. to L. Hayes on July 7, 1994). Some of the borehole information from the GENISES database (written commun. from E. Ezra to J. Nelson, April 29, 1994) differs from the 49 borehole survey data of RSN (written commun. from W. Kopatich to L. Hayes, June 17, 1994). Most of the northing (x) and easting $(y)$ values are within one foot, but elevation $(z)$ can differ by as much as eight $\mathrm{ft}$, and for UZ-14 by $75.3 \mathrm{ft}$. Some differences in $\mathrm{z}$ values of as much as two $\mathrm{ft}$ probably represent the difference between ground and collar elevations. Elevations of boreholes UZ-N38 
Table 3. Borehole locations from GENISES and Raytheon Services of Nevada [Nevada State Coordinates and elevations are in feet]

\begin{tabular}{|c|c|c|c|c|c|c|c|c|c|}
\hline \multicolumn{2}{|c|}{$\begin{array}{l}\text { Borehole } \\
\text { designator }^{a}\end{array}$} & \multirow{2}{*}{$\begin{array}{l}\text { Northing } \\
770500.2\end{array}$} & \multirow{2}{*}{$\begin{array}{l}\text { Easting } \\
561000.5\end{array}$} & \multirow{2}{*}{$\begin{array}{c}\text { Elevation } \\
4348.6\end{array}$} & \multicolumn{2}{|c|}{$\begin{array}{l}\text { Borehole } \\
\text { designator }\end{array}$} & \multirow{2}{*}{$\begin{array}{r}\text { Northing } \\
770069.9\end{array}$} & \multirow{2}{*}{$\begin{array}{l}\text { Easting } \\
561192.2\end{array}$} & \multirow{2}{*}{$\begin{array}{r}\text { Elevation } \\
4331.7\end{array}$} \\
\hline USW & $G-I$ & & & & USW & UZ-N33 & & & \\
\hline USW & $G-2$ & 778824.2 & 560503.9 & 5098.4 & USW & UZ-N34 & 770158.7 & 561251.5 & 4324.2 \\
\hline USW & G-3 & 752779.8 & 558483.1 & 4856.5 & USW & UZ-N35 & 762263.8 & 562310.0 & 4246.9 \\
\hline USW & $G-4$ & 765807.1 & 563081.6 & 4166.9 & USW & UZ-N36 & 773899.5 & 563582.7 & 4642.0 \\
\hline USW & $H-1$ & 770254.3 & 562388.0 & 4274.4 & USW & UZ-N37 & 767499.1 & 563713.5 & 4123.9 \\
\hline USW & $H-3$ & 756542.1 & 558451.7 & 4866.4 & USW & UZ-N38 & 767466.4 & 563343.4 & 4148.9 \\
\hline USW & $H-4$ & 761643.6 & 563911.1 & 4096.5 & USW & UZ-N53 & 760095.9 & 564236.9 & 4056.0 \\
\hline USW & $H-5$ & 766634.3 & 558908.7 & 4850.8 & USW & UZ-N54 & 760272.0 & 564262.2 & 4045.9 \\
\hline USW & $H-6$ & 763298.9 & 554074.9 & 4270.6 & USW & UZ-N55 & 760502.9 & 564248.3 & 4072.6 \\
\hline UE-25 & NRG\#1 & 765358.6 & 569803.1 & 3754.6 & USW & UZ-N57 & 755164.5 & 560829.9 & 4183.7 \\
\hline UE-25 & NRG\#2 & 765763.8 & 569162.1 & 3796.7 & USW & UZ-N58 & 755240.4 & 560862.2 & 4179.2 \\
\hline UE-25 & NRG\#2A & 765699.9 & 569001.1 & 3780.6 & USW & UZ-N59 & 755321.3 & 560888.4 & 4179.8 \\
\hline UE-25 & NRG\#2B & 765765.2 & 569214.5 & 3801.4 & USW & UZ-N61 & 755375.9 & 560894.0 & 4182.2 \\
\hline UE-25 & NRG\#2C & 765771.1 & 569189.8 & 3801.2 & USW & UZ-N62 & 757125.2 & 558302.7 & 4875.5 \\
\hline UE-25 & NRG\#2D & 765825.1 & 569132.3 & 3792.1 & USW & UZ-N64 & 765728.5 & 559435.8 & 4790.9 \\
\hline UE-25 & NRG\#3 & 766250.6 & 568316.1 & 3823.3 & UE-25 & UZN\#63 & 768836.5 & 566169.4 & 3944.1 \\
\hline UE-25 & NRG\#4 & 767080.2 & 566820.0 & 4099.4 & UE-25 & WT\#14 & 761650.6 & 575210.1 & 3529.9 \\
\hline UE-25 & NRG\#5 & 767889.6 & 564769.9 & 4106.1 & $U E-25$ & WT\#16 & 774419.7 & 570394.9 & 3971.4 \\
\hline USW & NRG-6 & 766726.3 & 564187.2 & 4092.2 & $U E-25$ & WT\#17 & 748419.6 & 566211.9 & 3688.5 \\
\hline USW & NRG-7A & 768880.0 & 562984.1 & 4207.0 & $U E-25$ & WT\#18 & 771167.1 & 564855.0 & 4383.0 \\
\hline$U E-25$ & $R F \# 3$ & 765575.1 & 571100.0 & 3657.7 & $U E-25$ & WT\#4 & 768511.8 & 568040.2 & 3829.1 \\
\hline$U E-25$ & $R F \# 8$ & 765630.8 & 568789.9 & 3787.9 & $U E-25$ & WT\#6 & 780575.8 & 564523.9 & 4306.9 \\
\hline$U E-25$ & $U Z \# 16$ & 760535.2 & 564857.5 & 4001.0 & $U S W$ & $W T-I$ & 753940.6 & 563739.2 & 3942.0 \\
\hline$U E-25$ & UZ\#4 & 768715.6 & 566139.3 & 3938.5 & USW & WT-10 & 748770.9 & 553302.1 & 3686.0 \\
\hline$U E-25$ & UZ\#5 & 768591.0 & 566135.2 & 3951.6 & USW & WT-2 & 760660.5 & 561923.6 & 4269.7 \\
\hline USW & $U Z-1$ & 771275.8 & 560220.8 & 4426.1 & USW & $W T-7$ & 755569.8 & 553891.3 & 3927.2 \\
\hline USW & $U Z-13$ & 751953.2 & 558488.7 & 4815.8 & $U E-25$ & $A \# 1$ & 764900.2 & 566350.0 & 3932.8 \\
\hline USW & $U Z-14$ & 771309.4 & 560141.3 & 4426.2 & $U E-25$ & $A \# 4$ & 767971.9 & 564471.6 & 4100.7 \\
\hline USW & $U Z-6$ & 759731.0 & 558325.0 & 4924.5 & $U E-25$ & A\#5 & 766956.4 & 564755.1 & 4056.5 \\
\hline USW & UZ-7 & 760836.1 & 562911.3 & 4169.3 & $U E-25$ & A\#6 & 765899.5 & 564500.7 & 4052.9 \\
\hline USW & UZ-N11 & 780573.9 & 559020.9 & 5224.0 & $U E-25$ & A\#7 & 766249.9 & 565468.5 & 4004.6 \\
\hline USW & UZ-N15 & 778090.5 & 559551.8 & 5109.4 & $U E-25$ & $B \# 1$ & 765243.4 & 566416.4 & 3939.0 \\
\hline USW & UZ-N16 & 778150.8 & 559626.0 & 5116.6 & $U E-25$ & $C \# 1$ & 757095.9 & 569680.4 & 3708.7 \\
\hline USW & UZ-N17 & 778224.1 & 559995.1 & 5127.9 & UE-25 & $\mathrm{CH2}$ & 756848.8 & 569633.8 & 3714.1 \\
\hline USW & UZ-N27 & 771569.7 & 558872.0 & 4859.5 & UE-25 & C\#3 & 756909.9 & 569554.9 & 3714.2 \\
\hline USW & UZ-N31 & 764245.7 & 562751.9 & 4151.8 & $U E-25$ & $P \# I$ & 756171.2 & 571484.5 & 3654.0 \\
\hline \multirow[t]{2}{*}{ USW } & UZ-N32 & 764302.6 & 562799.6 & 4158.0 & USW & $S D .9$ & 767988.6 & 561818.0 & 4272.5 \\
\hline & & & & & USW & $S D-12$ & 761956.6 & 561605.7 & 4343.0 \\
\hline
\end{tabular}

a $Q$ status designated by RSN: bold, $Q$ of as-built location with survey completed after rig is removed from borehole; bold italics, $Q$ of proposed location; plain, non- $Q$ with possible upgrade after historical review; italics, non-Q pre-1989 surveys.

8 Distribution of Lithostratigraphic Units Within the Central Block of Yucca Mountain, Nevada: A Threo-Dimensional Computer-Based Model, Version YMP.R2.0 
and UZ-N54 are from survey records of RSN

(W. Kopatich, June 17, 1994, written commun. to

L. Hayes) because this information was not included in the listing from GENISES. The elevation of UZ-14 from GENISES differed $75.3 \mathrm{ft}$ from the RSN data. The RSN elevation for UZ-14 was used because it is consistent with the elevation of UZ-1 on the same drill pad.

All but three boreholes are near vertical, and deviation surveys have been run for many of the boreholes. At the time boreholes were incorporated into the model, Q status deviation surveys were not available for the post-1992 boreholes, therefore, these boreholes are modeled as vertical. For the boreholes drilled prior to 1992 , the deviation surveys are non- $Q$ documents (Appendix 4). Three boreholes (A\#7, NRG\#2, and NRG\#3) were drilled about $30^{\circ}$ from vertical and are modeled as inclined boreholes.

Lithologic logs collected by the USGS Rock Characteristics Group since 1992 are Q status, but some non-Q core has been logged under the $Q A$ program. Lithologic logs completed prior to 1989 are not QA and are supporting data only. Source data for lithologic contacts include: 14 Q-status graphical logs, 24Q-status tables of contacts, 2Q-status graphical logs of non- $Q$ core, 1 Q-status table of contacts on non- $Q$ core from three pre-1989 boreholes, and 35 nonQ-status published or nonpublished logs from pre-1989 non-Q core, cuttings, or borehole geophysical logs (Appendix 3). The non-Q status of data from pre-1989 boreholes, including core samples and the analyses from these samples, might be upgraded to $Q$ status, but no action by the project has been implemented to facilitate this upgrade. Sixty-seven boreholes penetrate one or more of the modeled lithostratigraphic units. Eight boreholes penetrate one or more lithostratigraphic units in the Tiva Canyon Tuff, but these boreholes have a total depth (TD) in the crystallized undifferentiated model unit Tpcun. All lithostratigraphic data are from the USGS Local Record Center (LRC) in Denver, Colorado.

\section{FAULTS}

Faults are represented in the lithostratigraphic model by subblock-bounding faults that have vertical separations of lithostratigraphic units across the faults (fig. 1, table 4 and 5), and in an ancillary model of fault geometry where no separations of lithostratigraphic units are portrayed (table 5 and 6). Vertical separation and fault plane dip data were obtained from the surface geologic data of Scott and Bonk (1984), except where superseded by (1) detailed mapping (Spengler and others, 1993; 1994), (2) borehole intercepts with faults such as the Bow Ridge fault, or (3) geometric constraints based on modeled surfaces in nearby boreholes.

Scott (1990) summarized the vertical separation across some of the subblock-bounding faults, calculated an average dip on many faults of approximately $77^{\circ} \mathrm{W}$ with dips varying between $58^{\circ}$ and $88^{\circ}$, and discussed the change from steep dips at high elevations on a fault to slightly less steep dips at lower elevations on the same fault. The geologic map (Scott and Bonk, 1984) was examined in detail to expand on these general relations. Where vertical separation was derived from the geologic map (Scott and Bonk, 1984), the separation was determined on contacts of bedded tuffs, the Yucca Mountain and Pah Canyon Tuffs, and units of the Tiva Canyon Tuff across the fault trace relative to topographic contour lines. Dips were obtained from the geologic map (Scott and Bonk, 1984) where (1) the dip and strike of scarps are labeled on map (the value closest to mean was used where multiple values exist), or (2) a three-point determination with a minimum of $60 \mathrm{ft}$ of topographic relief across a ridge or valley. Faults of unknown attitude that are adjacent and parallel to faults of known attitude are assigned the attitude of the adjacent fault. Faults that do not have the information derived from the above methods are assumed to be vertical.

Table 4. Designators of block- and subblock-bounding faults within Lynx

[Block-bounding faults and structures are coded white (Lynx color 1)]

\begin{tabular}{cl}
\hline Designator & \multicolumn{1}{c}{ Fault or fault portion } \\
\hline 1 & Bow Ridge \\
$2 \mathrm{a}$ & Drill Hole Wash (north of Block E) \\
$2 \mathrm{~b}$ & Drill Hole Wash (south of Block E) \\
$3 \mathrm{a}$ & Abandoned Wash \\
$3 \mathrm{~b}$ & Ghost Dance \\
4 & Sever Wash \\
$5 \mathrm{a}$ & Solitario Canyon (southern portion) \\
$5 \mathrm{~b}$ & Solitario Canyon (central portion) \\
$5 \mathrm{c}$ & Solitario Canyon (northeast-trending spur) \\
$5 \mathrm{~d}$ & Solitario Canyon (northern portion) \\
6 & Yucca Wash (block boundary not modeled with \\
& any separation) \\
$7 \mathrm{a}$ & Dune Wash \\
$7 \mathrm{~b}$ & Dune Wash (northwest-trending spur) \\
\hline
\end{tabular}

Major subblock-bounding faults in the lithostratigraphic model include the Bow Ridge, Solitario Canyon, Sever Wash, Drill Hole Wash, Ghost Dance, Abandoned Wash, and the Dune Wash faults (fig. 1). 
Table 5. Separation and dip data for faults with greater than $20 \mathrm{ft}$ of vertical separation or strike-slip faults [Data from Scott and Bonk (1984) unless otherwise noted]

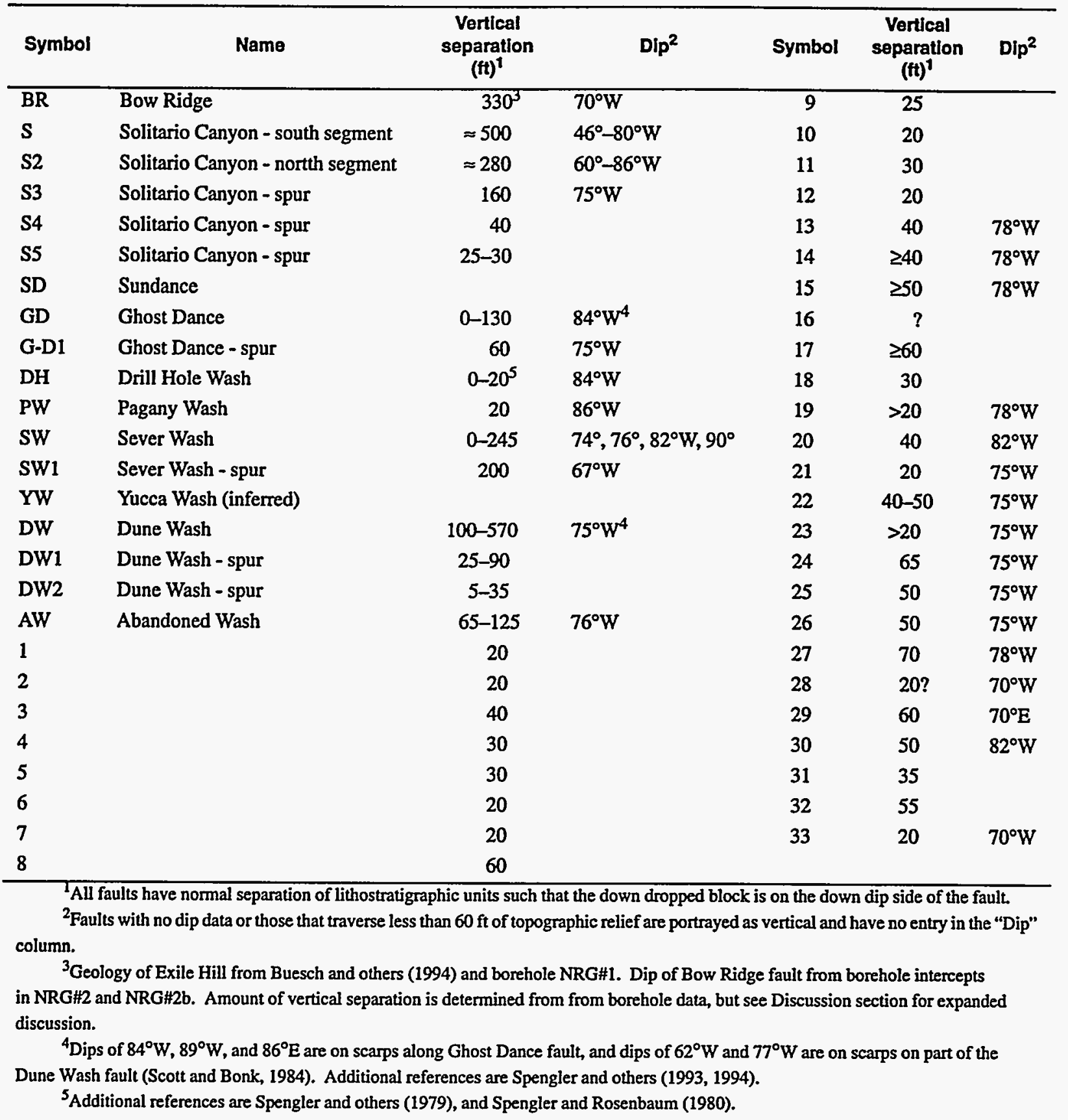


Block-bounding faults are the only faults in YMP.R2.0 that portray vertical separation of lithostratigraphic units across the faults. Faults are modeled with constant separation along the dip. Most subblockbounding faults have variable amounts of separation along the strike of the fault (table 5, fig. 2). For users of the model, subblock-bounding faults are accessed in YMP.R2.0 with model identification $G, Z F$, wherein $G$ is the Lynx default for 3-D geologic volume model files, and ZF is the identifier name of specific faults (table 4). Several modeled subblocks have nonfaulted boundaries (dashed lines in fig. 1).]

Table 6. Separation and dip data for faults with 10 to $20 \mathrm{ft}$ of vertical separation ${ }^{1}$

[Data from Scott and Bonk (1984) unless otherwise noted]

\begin{tabular}{|c|c|c|}
\hline Symbol & Name of fault & Dip $^{2}$ \\
\hline 56 & Solitario Canyon - spur & \\
\hline S7 & Solitario Canyon - spur & $78^{\circ} \mathrm{W}$ \\
\hline $\mathrm{G}-\mathrm{D} 2^{3}$ & E. Ghost Dance & \\
\hline G-D $3^{3}$ & W. Ghost Dance - north segment & \\
\hline G-D4 ${ }^{3}$ & W. Ghost Dance - south segment & \\
\hline \multicolumn{3}{|l|}{33} \\
\hline \multicolumn{3}{|l|}{34} \\
\hline \multicolumn{3}{|l|}{35} \\
\hline \multicolumn{3}{|l|}{36} \\
\hline 37 & & $76^{\circ} \mathrm{W}$ \\
\hline \multicolumn{3}{|l|}{38} \\
\hline 39 & & $55^{\circ} \mathrm{W}$ \\
\hline \multicolumn{3}{|l|}{40} \\
\hline \multicolumn{3}{|l|}{41} \\
\hline \multicolumn{3}{|l|}{42} \\
\hline \multicolumn{3}{|l|}{43} \\
\hline \multicolumn{3}{|l|}{44} \\
\hline \multicolumn{3}{|l|}{45} \\
\hline \multicolumn{3}{|l|}{46} \\
\hline 47 & & $77^{\circ} \mathrm{W}$ \\
\hline \multicolumn{3}{|l|}{48} \\
\hline \multicolumn{3}{|l|}{49} \\
\hline \multicolumn{3}{|l|}{50} \\
\hline \multicolumn{3}{|l|}{51} \\
\hline 52 & & $75^{\circ} \mathrm{W}$ \\
\hline 53 & & $75^{\circ} \mathrm{W}$ \\
\hline 54 & & $65^{\circ} \mathrm{W}$ \\
\hline $\begin{array}{l}\text { 'Sour } \\
\text { accurately th } \\
{ }^{2} \text { Fault } \\
60 \mathrm{ft} \text { of topo } \\
\text { entry in the } \\
{ }^{3} \text { Trace }\end{array}$ & \multicolumn{2}{|c|}{$\begin{array}{l}60 \mathrm{ft} \text { of topographic relief are portrayed as vertical and have no } \\
\text { entry in the "Dip" column. } \\
\text { 3Trace of these faults from Spengler and others (1993) and }\end{array}$} \\
\hline Spengler, wr & n commun., 1994. & \\
\hline
\end{tabular}

Several assumptions are used in modeling faults, especially the geometry of subblock-bounding faults (Appendix 2). Detailed structural analysis of fault traces on the 1:12,000 map of Scott and Bonk (1984) indicates some of the variation in dip discussed by Scott (1990), but also shows that faults may have a reverse sense of separation. Changes in dip of a fault along the dip or strike can create volumetric problems that are difficult to resolve with the available data, therefore, faults are modeled with constant dip (table 5). Only the Solitario Canyon and Sever Wash faults are modeled with variable dips along the strike (table 5). Changes in the amount of vertical separation along the dip also create volumetric problems that are difficult to resolve with the available data, but where the strike remains relatively uniform, the amount of vertical separation can decrease; therefore, faults are modeled with constant separation along dip and variable separation along strike (table 5, fig. 2). Faults with apparent reverse separation are not modeled. Vertical separation across the modeled Ghost Dance fault represents the net separation for the entire system, which is locally as much as $1,200-\mathrm{ft}$ wide and may be different from the separation across only the main trace of the Ghost Dance fault (Scott and Bonk, 1984; Spengler and others, 1993, 1994; and preliminary data from A. Braun, USGS-SAIC, written commun., 1994). Thickness of each lithostratigraphic units is maintained across faults, an assumption consistent with dip-slip faults but not necessarily for strike-slip faults.

Faults are incorporated in the model through a series of steps that simplify the geometry and, therefore, may not replicate all the details implied on the map of Scott and Bonk (1984) (Appendix 2). These simplifying steps provide a consistency in the modeling method across areas of variable data density and quality and minimizes overly interpreting local map relations. Surface traces of faults were digitized from a paper copy of the map to produce a map of faults that locally have changing strike. These traces were projected to a depth of $4,000 \mathrm{ft}$ with an average constant dip (table 5 and 6 ) to form a structure contour on the fault. This $4,000 \mathrm{ft}$ structure contour was replicated to produce structure contours at $2,000,3,000$, and $5,000 \mathrm{ft}$ with the trigonometric tangent function of the dip for the fault. A modeled fault plane containing the structure contours was constructed and truncated by surface topography in a digital map based on 20 -ft contours. Differences in the location of individual fault traces may exist between this model, other models, the map of Scott and Bonk (1984), and the actual position of a fault on the ground for five main reasons: (1) Scale instability of the original map, (2) errors in digitizing fault traces, (3) the assumption of constant dip in the 


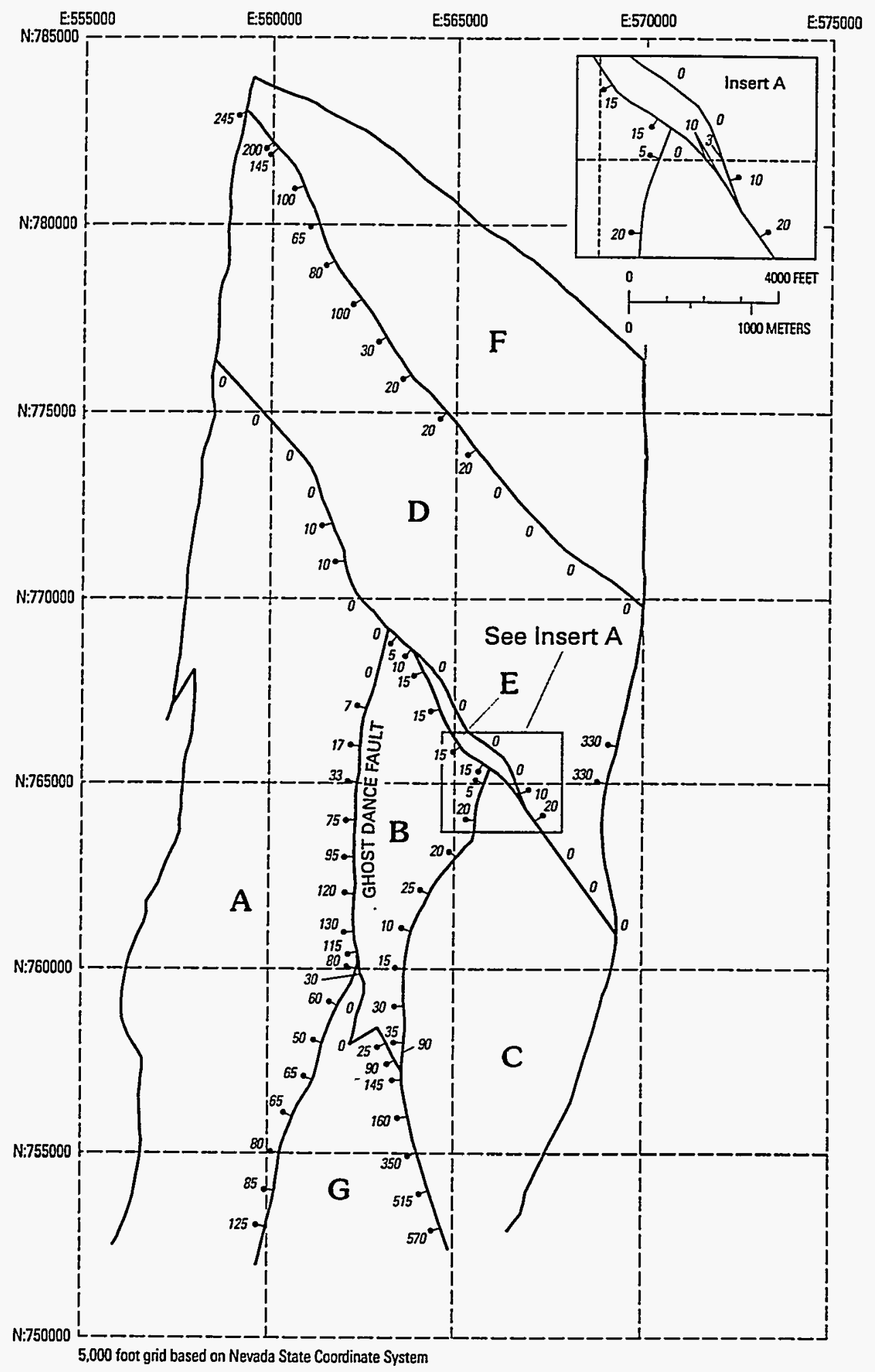

Figure 2. Map of variations in vertical separation along the length of subblock-bounding faults. Bar and ball indicates downthrown side; number indicates vertical separation in feet. Fault trace represents the lowest surface elevation of the fault. 
model whereas the mapped dip might change, (4) the simplifying method of geometric projections to form the modeled fault plane, and (5) small differences in registration of topographic and geological surface data.

The ancillary model of fault geometry illustrates the location and geometry of nonsubblock-bounding faults within the modeled area as shown on the 1:12,000 scale map of Scott and Bonk (1984); however, vertical separation is not portrayed for any faults in the ancillary model. The ancillary model can be displayed with the lithostratigraphic model to highlight areas in the model that have been simplified as a result of structural complexity. Faults in the ancillary model are divided into three categories that include faults with greater than $20 \mathrm{ft}$ of vertical separation (fig. 3a), faults with 10 to $20 \mathrm{ft}$ of vertical separation (fig. $3 \mathrm{~b}$ ), and faults with less than $10 \mathrm{ft}$ of vertical separation (fig. $3 \mathrm{c}$ ). In the ancillary model, the first two categories of faults are modeled by planes that extend approximately $500 \mathrm{ft}$ below the topographic trace of the fault; red planes (Lynx code 2) mark faults with greater than $20 \mathrm{ft}$ of separation, and blue planes (Lynx code 6) denote faults with 10 to $20 \mathrm{ft}$ of separation. Not all faults in subblock $C$ of the ancillary model are truncated by ground surface topography, a task that will be completed in future versions of the model. For users of YMP.R2.0, these two sets of faults are portrayed in the $\mathrm{G}, \mathrm{CF}$ model. Faults with less than $10 \mathrm{ft}$ of offset are portrayed solely as traces of faults and are represented in YMP.R2.0 as overlay q01. An additional fault map overlay (q02) contains the boundary line of the detailed map area along the Ghost Dance fault. Data contained in the map overlay q02 were acquired from recent detailed geologic mapping of the Ghost Dance fault (Spengler and others, 1993; 1994).

\section{MODELING METHODOLOGY}

The fundamental data that are input into the Lynx system consist of: (1) A digitized version of a handdrawn structure contour map on the base of the Tiva Canyon Tuff, (2) digitized versions of hand-drawn isochore maps for each model unit, and (3) a digitized map of fault traces for subblock-bounding faults, as described in the previous section (fig. 4). Data for these maps consist of logs from recently drilled boreholes, previously published logs, and reexamination of some previously logged boreholes. Data are entered into the master ARC/INFO database, and depths of lithologic contacts are used in ARC/INFO to calculate apparent thickness of units and elevation of the contacts. A map of borehole locations and elevations of the base of the Tiva Canyon Tuff is printed, and a hand-drawn structure contour map is created. This structure contour map on the base of the Tiva Canyon Tuff is the base of model unit Tpcpv. Maps of borehole location and unit thickness are printed, and hand-drawn isochore maps are created. Linear interpolation is used in construction of hand-drawn structure contour and isochore maps. Errors associated with using linear interpolation are described in the Discussion section and Appendix 2. Locally, the linear interpolation method and the configuration of borehole pairs result in irregular or convoluted isochores that are smoothed based on reasonable geometric and geologic interpretation. Data and technical reviews of interpretations are conducted at several steps along this process. After the final review, digitized maps are imported into Lynx.

Lithostratigraphic units are modeled in YMP.R2.0 as structure contour maps on the base of each unit, and these maps consist of $x, y$, and $z$ data that are triangulated to form the surfaces. The $x, y$, and $z$ points on surfaces consist of borehole data, and digitized points along input structure or isochore contours that are determined by the spacing of points during digitization, or are the result of combining two maps to form a third map that contains all points from the initial two maps. The map of each surface in a structural subblock can contain as many as 5,000 data points. Triangulation, using the surface-handling technique that is part of the LYNX software, utilizes the Delauney tessellation method (Hamilton and Jones, 1992; and Davis, 1986). This tessellation method is based on linear interpolation where triangles are generated that are as equiangular as possible. The triangulated network forms the basis for adding or subtracting surfaces to create new surfaces or determining the intersections of surfaces and faults.

In the surface modeling methods used in YMP.R2.0, the file structure consists of: (1) Input maps that extend across the modeled area and include the structure contour map at the base of the Tiva Canyon Tuff (Tpcpv, N01) and isochores (i n), and (2) the modeled surfaces that are truncated by faults $(\mathrm{N} \mathrm{n})$ (i is an isopach surface, and $n$ and $N$ are variables of surface and subblock identifier described in table 7). Surfaces are displayed by designating the geologic model (G), subblock identifier $(N)$, and the surface number $(n)$ (table 7).

Surface modeling in Lynx begins with displaying the subblock-bounding faults (fig. 1 and 2, table 4) and an input structure contour map (fig. 5 and 6). The base of the Tiva Canyon Tuff (base of the model Tpcpv unit; fig. 6) is used in the YMP.R2.0 model because this is the best constrained surface as it is penetrated by the largest number of boreholes and is locally exposed at the ground surface. The structure contour map is triangulated and edited to optimize geometry of the triangulation net (fig. 7). Figure 7 shows the typical number 


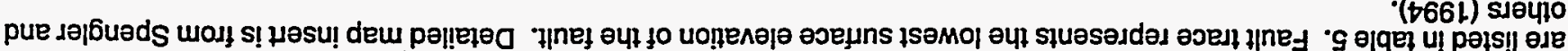

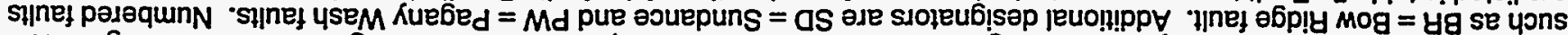

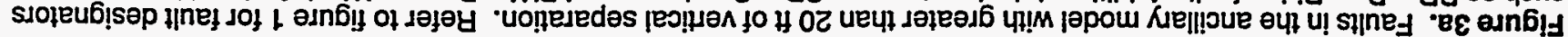

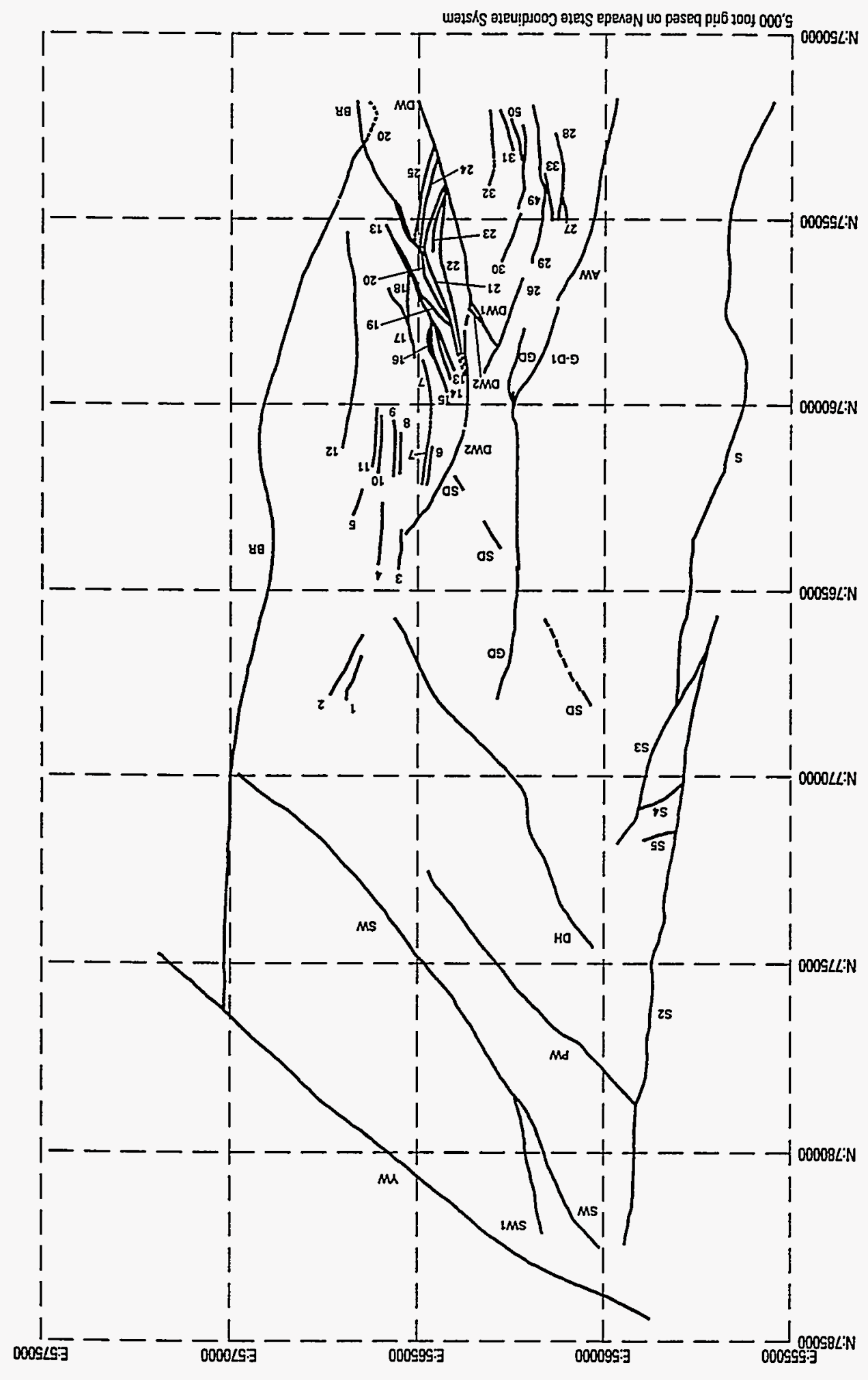




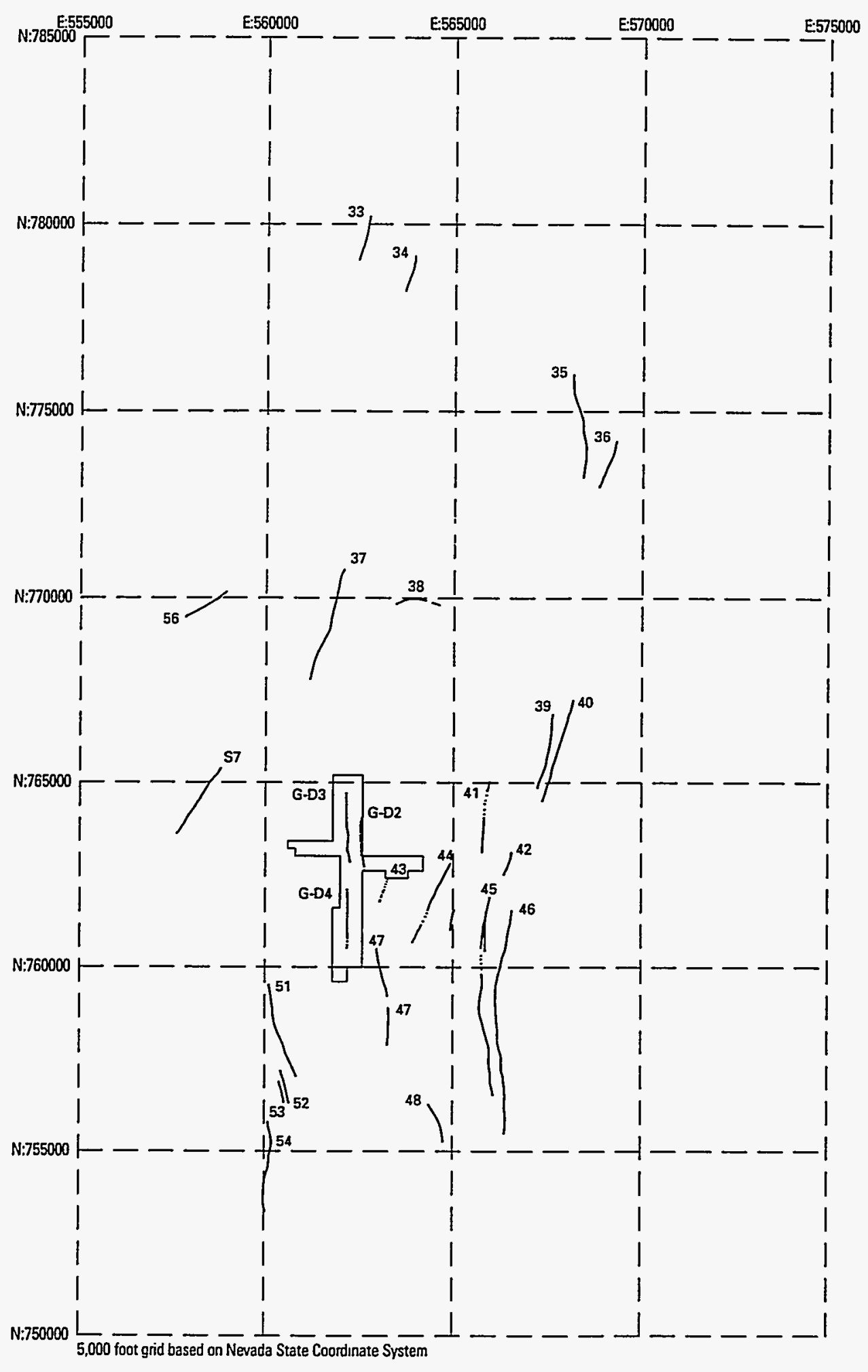

Figure 3b. Faults in the ancillary model with 10 to $20 \mathrm{ft}$ of vertical separation. Refer to figure 1 for fault designators. Numbered faults are listed in table 6. Fault trace represents the lowest surface elevation of the fault. Detailed map insert is from Spengler and others (1994). 


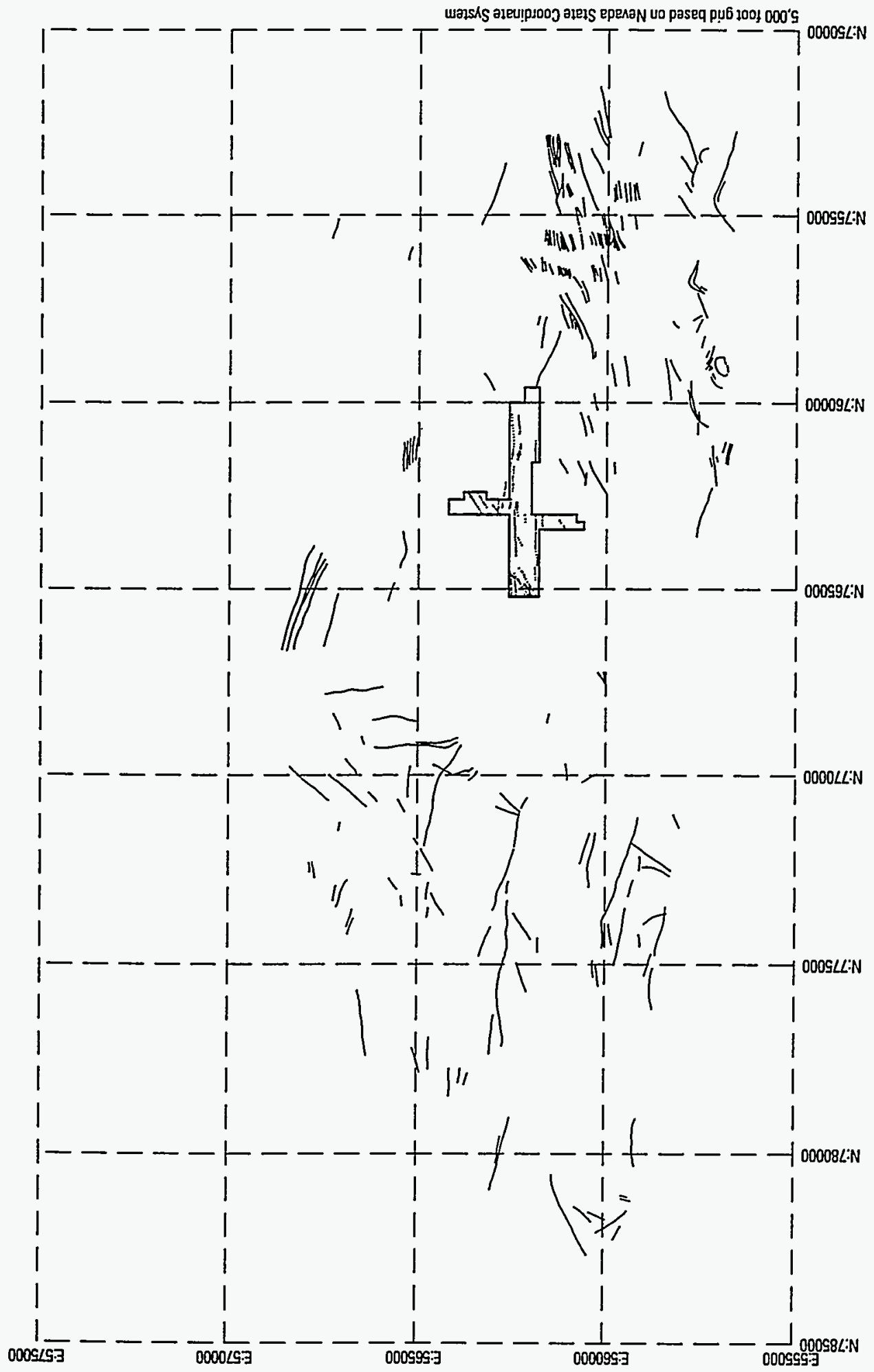




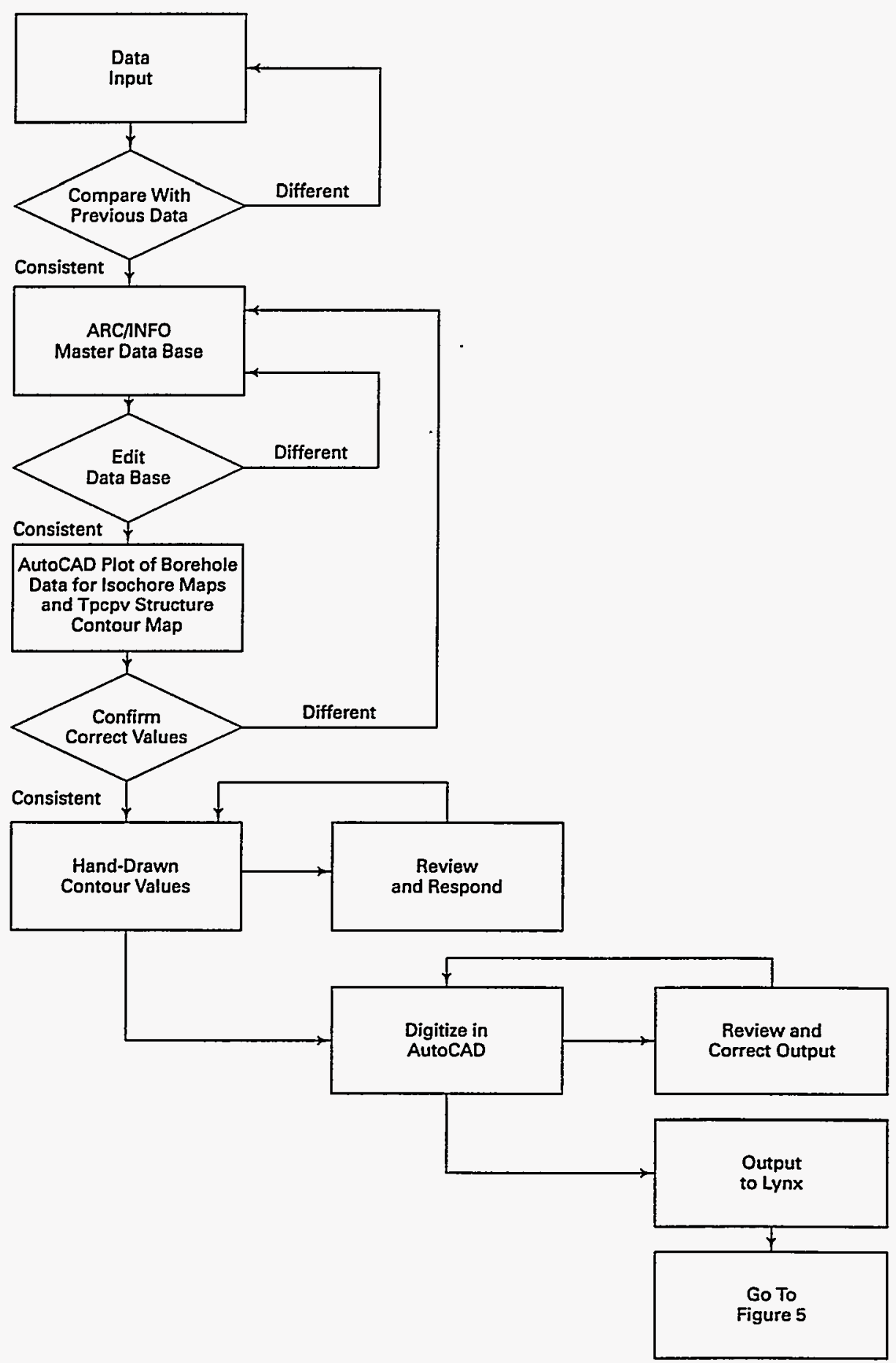

Figure 4. General flow diagram of the modeling process (pre-Lynx). 
Table 7. Surface model file structure for fault subblocks $A$ to $G$

\begin{tabular}{|c|c|c|c|c|}
\hline \multicolumn{4}{|c|}{ Input surface files } & Description \\
\hline $\begin{array}{l}\text { in } \\
i=\text { isochor } \\
n=\text { surface } \\
\text { s } n^{1}\end{array}$ & $\begin{array}{l}\text { surface } \\
\text { aumber }(01\end{array}$ & 13) & & Isochore map; complete model area coverage. \\
\hline \multicolumn{4}{|c|}{$\begin{array}{l}s=\text { surface elevation data } \\
n=\text { surface number }(01-13)\end{array}$} & $\begin{array}{l}\text { Point file containing base of unit surface elevations from } \\
\text { boreholes; complete model area coverage. }\end{array}$ \\
\hline $\begin{array}{l}N n \\
N=\text { fault st } \\
n=\text { surface }\end{array}$ & $\begin{array}{l}\text { bblock ( } A-1 \\
\text { aumber }(01\end{array}$ & $\begin{array}{l}\text { 1) } \\
\text { 13) }\end{array}$ & & Unit surface truncated at faults ${ }^{3}$ and thinned contour lines. \\
\hline \multicolumn{5}{|c|}{ Surface output from Lynx Model } \\
\hline \multicolumn{4}{|l|}{$\overline{\mathbf{G}, \mathbf{N}}$} & $\begin{array}{l}\text { Surface model composed of Lynx components representing } \\
\text { individual unit surfaces for each fault subblock. }\end{array}$ \\
\hline \multicolumn{5}{|c|}{$\mathrm{G}=$ geologic model type (Lynx default) } \\
\hline \multicolumn{5}{|c|}{$N=$ subblock $\mathrm{ID}(\mathrm{A}$ to $\mathrm{G})$} \\
\hline $\begin{array}{c}\text { Unit } \\
\text { surface }\end{array}$ & $\begin{array}{l}\text { Surface } \\
\text { number }\end{array}$ & $\begin{array}{c}\text { Lynx } \\
\text { number }\end{array}$ & Color & \\
\hline Tpcun & 11 & 14 & Aqua & \\
\hline Tpcpv & 01 & 2 & Red & \\
\hline Tpy & 02 & 6 & Blue & \\
\hline Tpbt3 & 03 & 1 & White & \\
\hline Tpp & 04 & 11 & Maroon & \\
\hline Tptrv & 05 & 3 & Yellow & \\
\hline Tptrn & 06 & 7 & Purple & \\
\hline Tptpul & 07 & 12 & Pink & \\
\hline Tptpln & 08 & 5 & Cyan & \\
\hline Tptpv3 & 09 & 13 & Coral & \\
\hline Tptpv1\&2 & 10 & 4 & Green & \\
\hline Tac & 12 & 6 & Blue & \\
\hline Tcp & 13 & 2 & Red & \\
\hline \multicolumn{5}{|c|}{$\begin{array}{l}\text { surface to form the final structure contour map and the initial files of borehole elevations are deleted. } \\
{ }^{2} \text { Fault subblock "F" is comprised of a northern block "a" and a southern block " } \mathrm{b} \text { " in the Lynx model for surfaces } \\
\text { Tpcpv (F1a, F1b), Tpy (F2a, F2b), and Tpbt } 3 \text { (F3a, F3b) to represent the discontinuous nature of these unit surfaces within } \\
\text { the fault subblock. } \\
{ }^{3} \text { Fault designators are presented in table } 4 \text {. }\end{array}$} \\
\hline
\end{tabular}


where:

b04 = preliminary structure contour map for projected beyond fault boundaries

05 = isopach map for surface 05 (Tptrv)

b05 = preliminary structure contour map for subjacent unit, surface 05 (ptrv) contour lines projected beyond fault boundaries

s05 = Borehole data base information for surface 05 (Tptrv)

B05 = Final structure contour map, clipped at fault boundaries merged with edited intersections (traverses) and borehole data

1 The surface examples given in this flow chart correlate with the figure 8 series (Figures $8 \mathrm{a}, 8 \mathrm{~b}$, and $8 \mathrm{c}$ )

2 Using the following process: Tptrv elevation $=T p p_{\text {elevation }}-T_{p t r v_{\text {thickness }}}$ surface 04 (Tpp), block B, contour lines

Digitize output from AutoCAD Istructure contour map and isopach maps

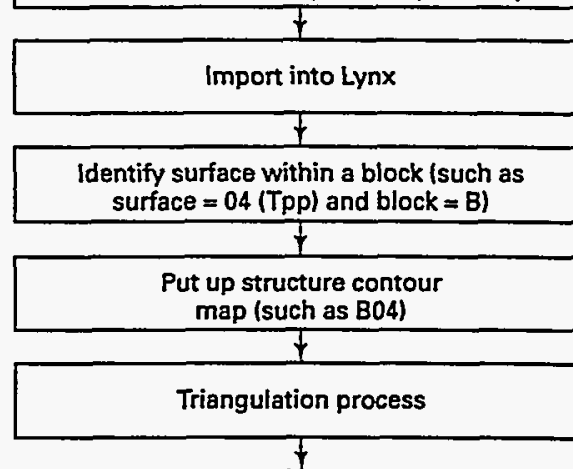

Get isopach map for subjacent unit (such as 05 for Tptrv)

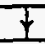

Merge isopach map onto triangulated surface of structure contour

Subract isopach map from structure contour map 1

Triangulation process

$$
1
$$

Resulting structure contour map is for subjacent surface (such as b05 for Tptrv)

$$
t
$$

Structure contour (such as b05 is compared to borehole data base (a05)

$$
1
$$

Intersect surface (such as b05) with

faults or non-faulted boundaries

Edit intersection (traverse) and use to clip b05 into B05

$$
\text { I }
$$

Merge edited intersection (traverse), s05 into $\mathrm{B05}$

B05 - final structure contour map (Appendix 5)

Repeat until surface set is complete

for blocks A-G using a 05, c05.. $\downarrow$

Repeat until all surfaces are

complete using b05, b06...

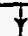

Use data visualizer (WAVEFRONT)

$$
\text { to examine data }
$$

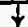

Make any necessary edits

Flgure 5. Flowchart of data manipulation within Lynx. 


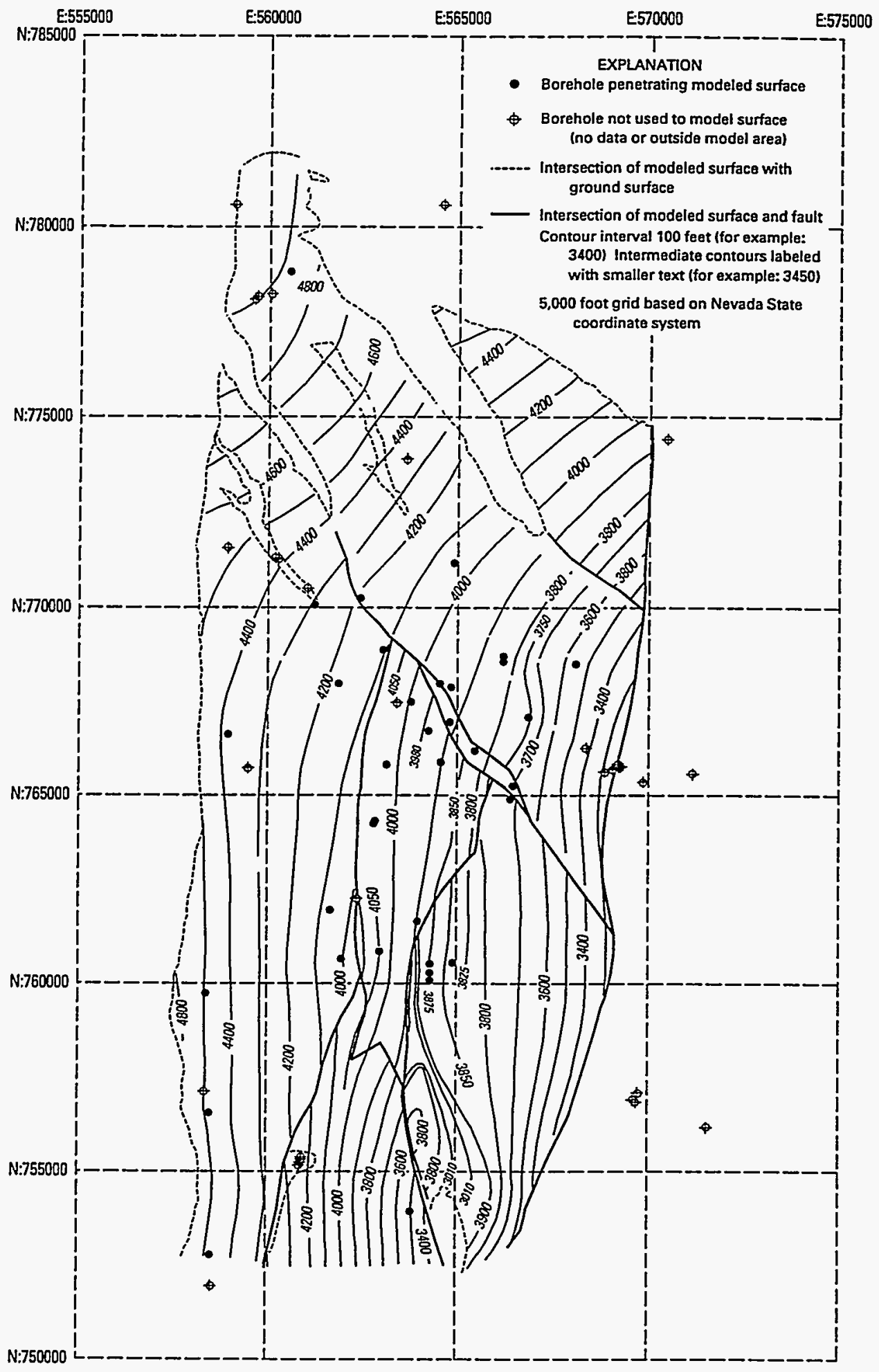

Figure 6. Structure contour map of the base of the Tiva Canyon Tuff (Tpcpv). 


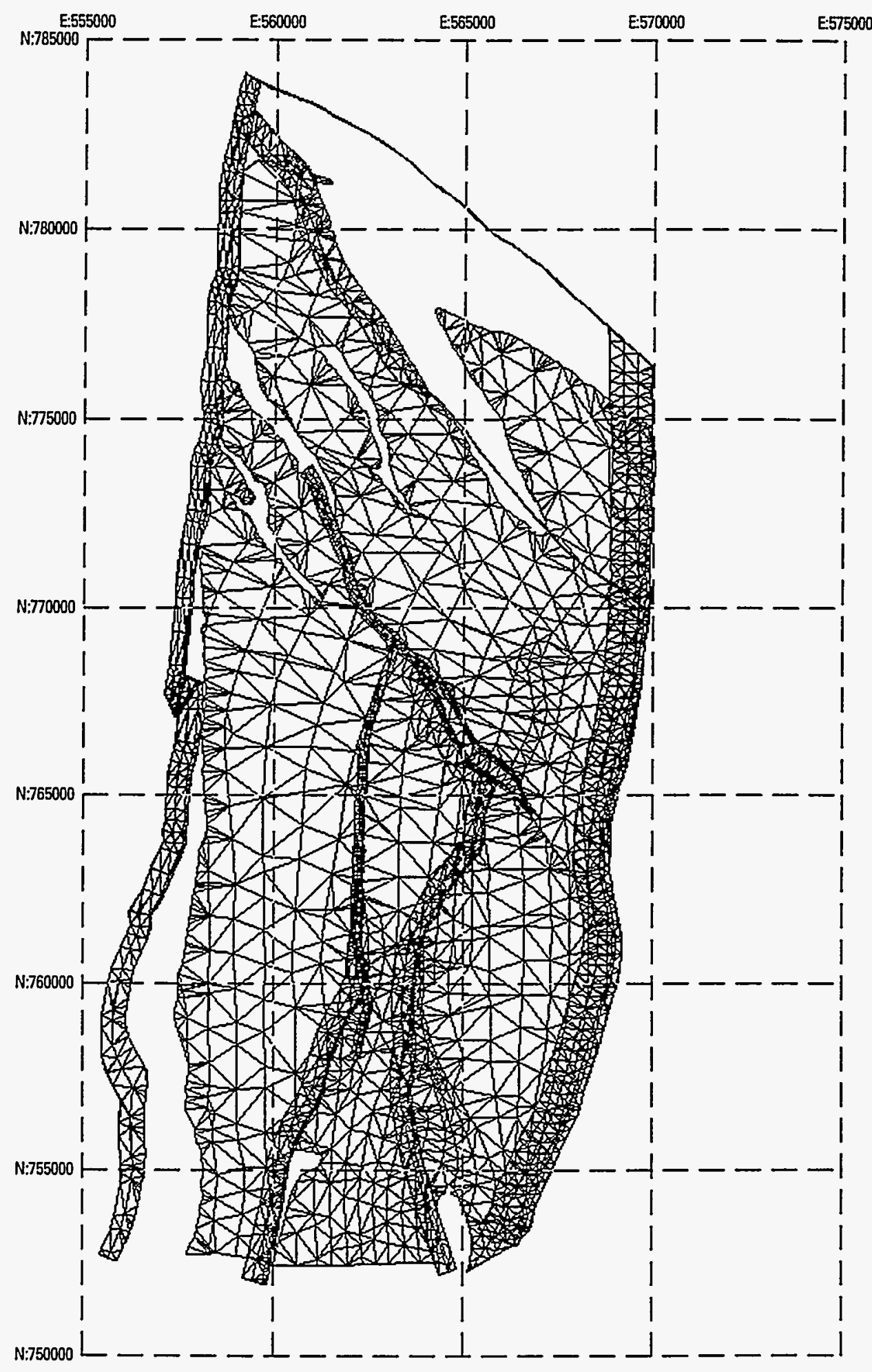

Figure 7. Triangulated surface of the base of Tiva Canyon Tuff structure contour combined with a triangulated map of the subblock-bounding faults. Areas of white, including those north of N 770000 and east of E 560000, are where the base of the Tiva Canyon Tuff has been eroded. White area in the southwest results from the distance between the trace of the Solitario Canyon fault and the surface exposure of the base of the Tiva Canyon Tuff. Nevada State Coordinates are in feet. 
of points along contour lines and the resulting triangulation net.

Each structure contour map at the base of a model unit is constructed by subtracting the model isochore thickness from the overlying structure contour map (fig. 5). This process is illustrated by working through development of the structure contour of the base of the Tptrv model unit from the structure contour map of the base of the Tpp model unit (fig. 8a) and the isochore map for the Tptrv model unit (fig. 8b). The structure contour map at the base of the Tpp model unit is a product of the modeling method and exemplifies the progression in modeling with use of a constructed surface as input to the adjacent surface. After the structure contour and isochore maps are triangulated and edited, the isochore values are subtracted from the altitude in the structure contour map and an preliminary structure contour map at the base of the Tptrv model unit is created (fig. 8c). The sequence of steps used in construction of surfaces is repeated for each surface and consists of numerous iterative editing steps and checks for geometric consistency (fig. 5).

Editing of the newly constructed structure contour map is required and consists of overlaying the borehole information to assist in determining geometric consistency (fig. 5). This preliminary structure contour map results from subtraction of maps that are based on linear interpolation, but a linear interpolated map is not necessarily produced. Reasons for these nonlinear relations include: (1) Difference in borehole density and density of points on the calculated structure contour maps, (2) use of linear interpolation with a sparse data set that does not yield reasonable results in a complex geological setting, (3) pinch out of units between boreholes, and (4) different sets of borehole pairs on each map that result from boreholes that do not penetrate all units (also see Appendix 2).

An additional step of editing is the insertion of intermediate structure contours where a change in orientation of the surface is poorly constrained or where contours on an elongate structural high or low minimize the formation of a horizontal triangulated surface (see, for example, subblock $\mathrm{C}$ in Appendix $5 f$ where subblock $\mathrm{C}$ is identified in fig. 1). These configurations can be problematic where model units are thin. Without the addition of intermediate contours, the units can locally thicken or thin, which is not supported by hard data such as from boreholes, or the surfaces on the base of units can cross, a configuration that may not be geologically possible.

The preliminary structure contour map is truncated by faults to form an intersection traverse. These intersection traverses are edited to ensure optimum tri- angulation and closure with the structure contour map (fig. 5).

Preparation of the final structure contour map in each subblock consists of merging the preliminary structure contour map, intersection traverse, and elevations of borehole intercepts of the surface (fig. 5). After the final structure contour map of the surface is produced, individual components of the preliminary structure contour map and borehole intercepts are deleted (fig. 5). A complete set of structure contour maps for each modeled lithostratigraphic unit is in Appendix 5.

\section{DISCUSSION}

This surface-based model, version YMP.R2.0, builds upon previous models and provides a framework for future modifications based on additional borehole data, refinements in geologic interpretation, and addition of modeled surfaces. The model is a useful tool for: (1) Validating previously published lithostratigraphic logs by comparing these logs to more recently acquired data and the modeled lithostratigraphic units, (2) examining the three-dimensional consistency of units, (3) illustrating areas where stratigraphic or structural complexity creates regions of uncertainty, and (4) visualizing and evaluating stratigraphic and structural relations that are poorly constrained or not previously recognized.

\section{Uses and Limitations of the Model}

YMP.R2.0 is a preliminary three-dimensional lithostratigraphic and structural model that is geometrically and internally consistent. A geometrically consistent model has model stratigraphic units, surfaces, and faults that fit together spatially without major overlaps or gaps. YMP.R2.0 was constructed from twodimensional isochore maps and a structure contour map that were based primarily on linear interpolation between data points with some geologic interpretation. Although these two-dimensional maps were individually reviewed for internal consistency, they do not necessarily produce a three-dimensional geometrically consistent model. Thus, in the editing of individual surfaces and final editing of the model, minor adjustments were made to attain geometric consistency. Enhancing the model to more accurately reflect the geology includes the addition of new and reexamined data on lithostratigraphic units and thickness variations of the units, refining how units pinch out, and the inclusion of more structures.

Structural relations from the $1: 12,000$ scale map of Scott and Bonk (1984) are used in construction of 


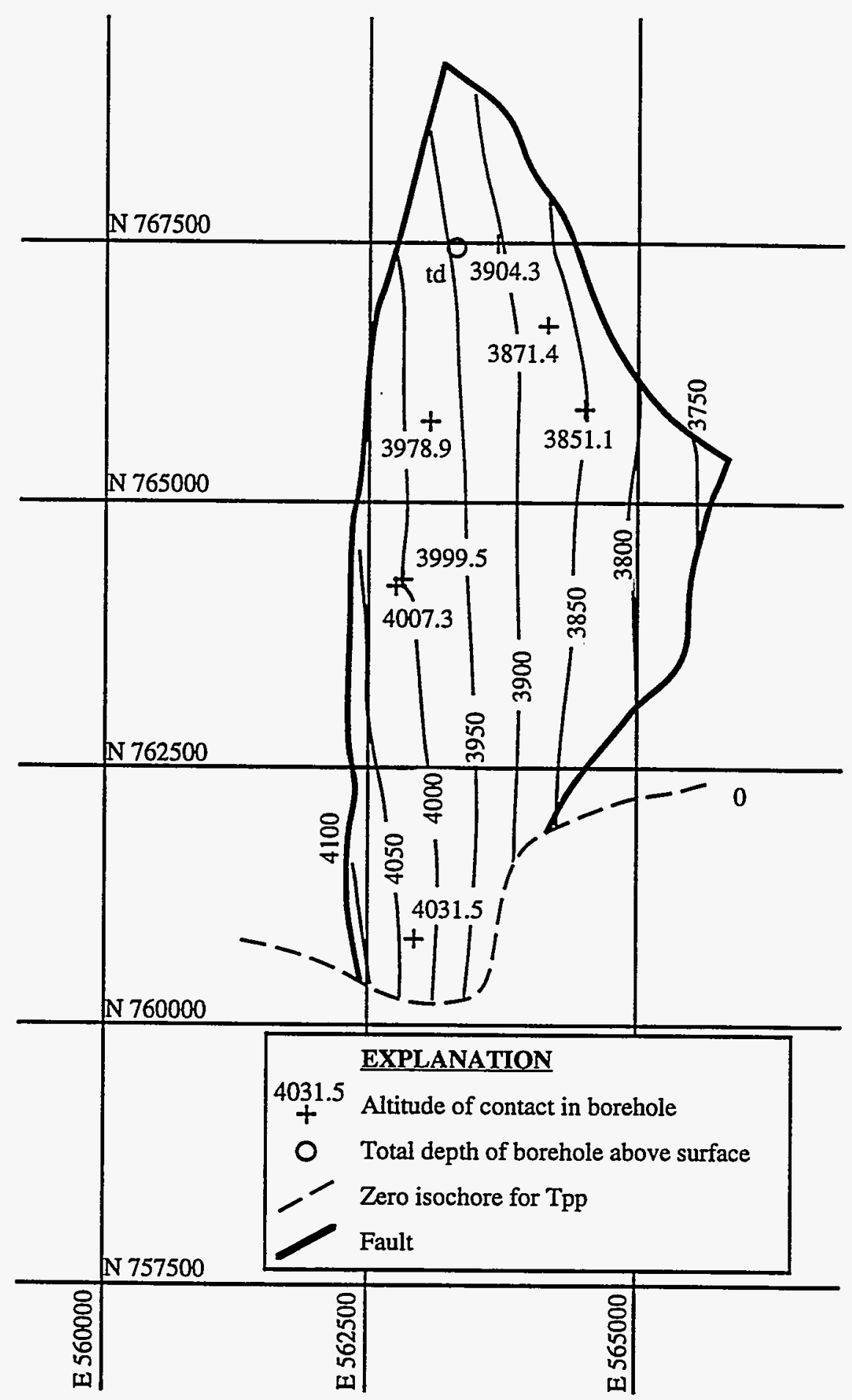

Figure 8a. Structure contour map of the base of Pah Canyon Tuff (Tpp) in model subblock B. The Pah Canyon Tuff pinches out south of the zero isochore line located between $N 760,000$ and $N 762,5000$. Map of the base of model unit Tpp is designated surface B04, and the isochore map of model unit Tpp is surface i04. Nevada State Coordinates are in feet. 


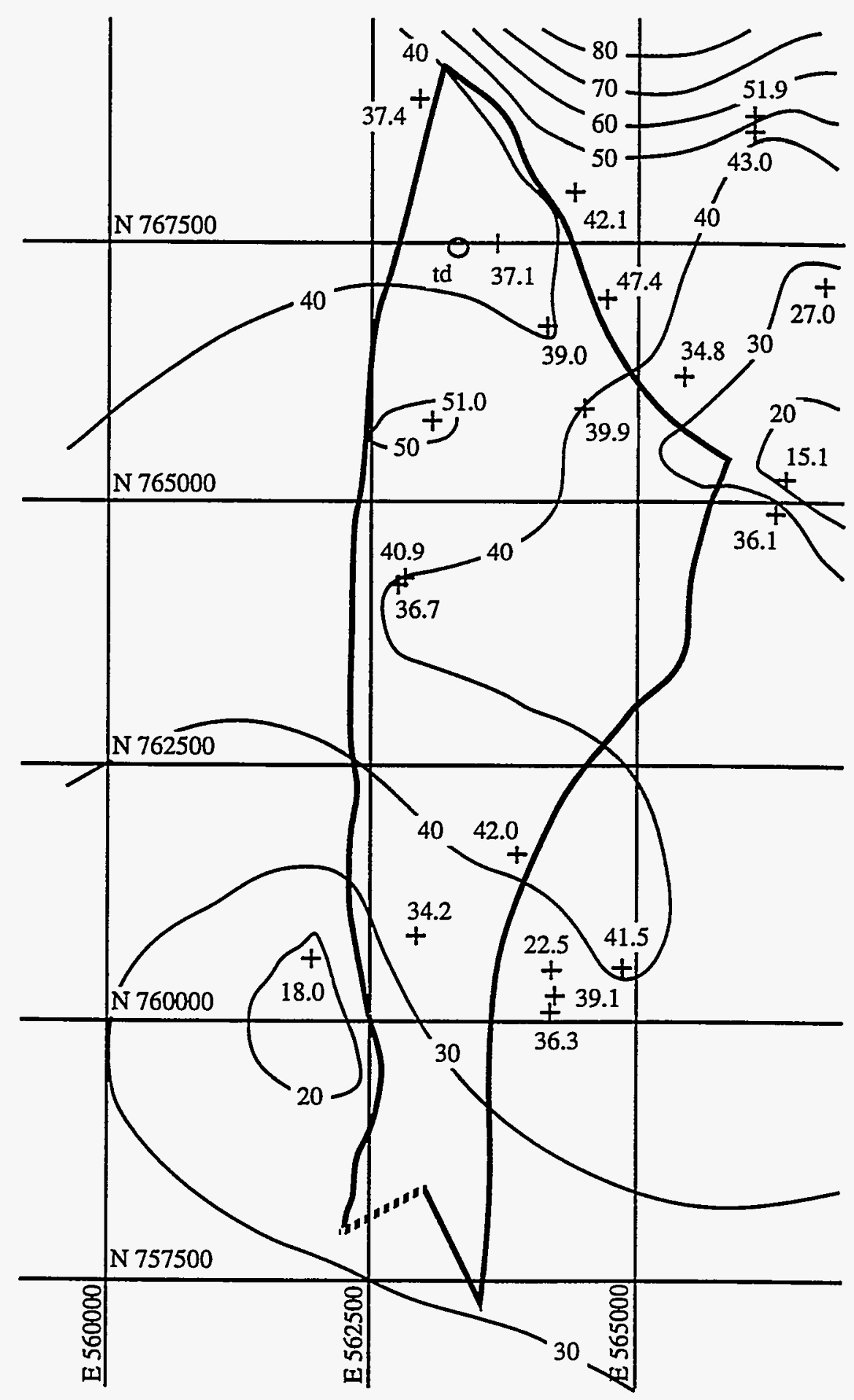

Figure 8b. Isochore map of model unit Tptrv (surface i05) that includes pre-Pah Canyon Tuff bedded tuff and vitric nonwelded to moderately welded Topopah Spring Tuff. Bounding faults for subblock B are overlain in bold. Symbols are as shown in fig. Ba. Nevada State Coordinates are in feet. 


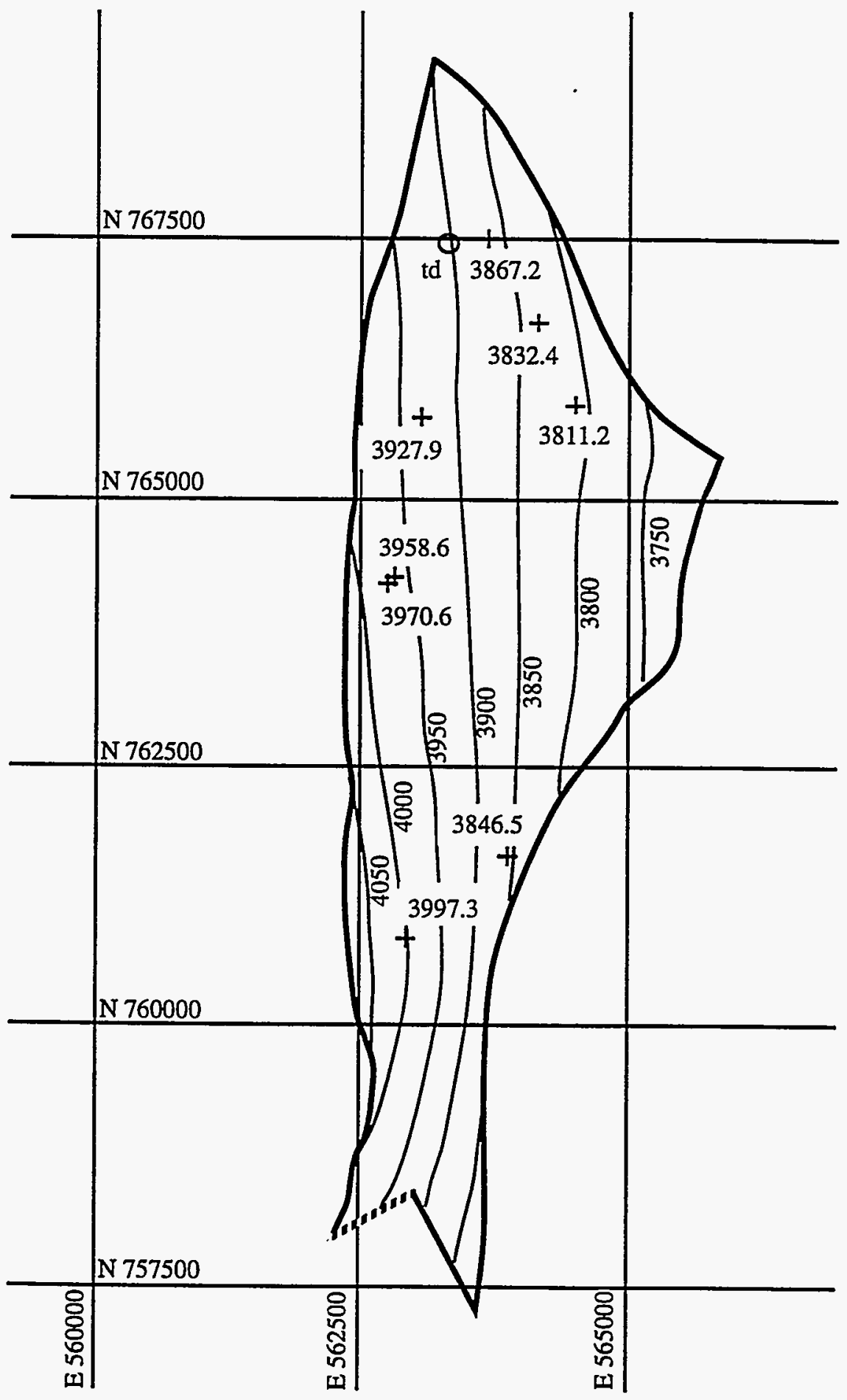

Figure 8c. Structure contour map of the base of model unit Tptrv in subblock B (surface B05). Symbols are as shown in fig. 8a. Nevada State Coordinates are in feet. 
the lithostratigraphic model YMP.R2.0, but borehole data are the primary input where the two yield different results. The prime reason for this emphasis is that the majority of lithostratigraphic units, including most of the Topopah Spring Tuff that is targeted for the ESF and potential repository, are only accessible in the subsurface by boreholes or in limited surface exposures along the periphery of Yucca Mountain. Thickness and elevation of contacts of some lithostratigraphic units in boreholes such as $\mathrm{H}-3$ and $\mathrm{H}-5$ differ by as much as $100 \mathrm{ft}$ from relations mapped by Scott and Bonk (1984) along the west flank of Yucca Mountain. Mapping the west flank of Yucca Mountain is underway to establish precise locations of contacts that will help resolve some of the local differences in using borehole versus map relations, but a more widespread revision of the map of Scott and Bonk (1984) may be required to successfully integrate these two types of data.

Regions of uncertainty within the model include areas with sparse subsurface data such as the northwest portion of the study area (subblocks $D$ and $F$ in fig. 1), regions of complex geology such as the intensely faulted southeast portion of the study area (fig. 3 in subblocks $C$ and $G$ identified in fig. 1), and the deeper modeled lithostratigraphic units. Drill Hole Wash, even with the number of boreholes, remains a poorly understood area because of complex faulting and the changes in thickness of many lithostratigraphic units (Buesch and others, 1994). In areas where lithostratigraphic units are thin such as the southern part of the mountain, there is an increased amount of uncertainty in the thickness of a unit or position of a contact. These are the same areas of uncertainty outlined in the earlier volume-based demonstration model (YMP.R0), but the increased number of boreholes in version YMP.R2.0 translates to a lower overall uncertainty.

There are areas in the model where local changes in orientation of lithostratigraphic units and numerous faults, which do not have any modeled separations, combine to form simplified or apparent structures. Areas of simplified or apparent structures can be highlighted by displaying the ancillary fault geometry model with the lithostratigraphic model. In the southeastern part of the model area, east of Dune Wash fault, the apparent fold in the structure contour map on the base of the Tiva Canyon Tuff (fig. 6) results from not modeling the separation across any faults in an area known to be structurally complex (fig. 3a). Modeled units in the eastern end of subblock D dip more steeply than at the western end, and the change to steeper dips occurs near NRG\#4. The change to steeper dips is in part real and in part a function of not modeling the separations of the numerous faults that have $10 \mathrm{ft}$ or more of separation (Scott and Bonk, 1984; Buesch and others, 1994; fig. 3). In areas where the structure has been simplified, the apparent stratigraphic thickness of modeled units is not well constrained and can show anomalous thickening and thinning.

\section{Application of the Model to Site-Scale Geometric Relations}

Prior to construction of this model, examination and evaluation of the three-dimensional stratigraphic and structural relations at Yucca Mountain were facilitated using cross sections, including fence diagrams in a few studies, and even fewer studies presented structure contours (Spengler and Rosenbaum, 1980; Carr, 1984; Scott and Bonk, 1984; Scott and Castellanos, 1984; Broxton and others, 1986; Byers and Moore, 1987; Spengler and Fox, 1989; Scott, 1990; Wittwer and others, 1992). This three-dimensional lithostratigraphic model, version YMP.R2.0, enables examination of various stratigraphic and structural features in a complete and integrated setting.

The model shows the spatial variation in thickness of lithostratigraphic units that are the focus of many site characterization activities. The Paintbrush nonwelded hydrogeologic unit, which is represented by the model units Tpcpv, Tpy, Tpbt3, Tpp, and Tptrn (table 2), thins to the south and slightly to east, but individual units thin in different areas. This hydrogeologic unit is suspected of having a significant influence on the hydrologic infiltration rate (Flint and Flint, 1994) and lateral flow in the unsaturated zone (Bodvarsson and others, 1994). The thickest part of the Topopah Spring Tuff is coincident with the eastern half of the proposed repository; however, the thickest parts of individual lithostratigraphic units are not necessarily coincident with each other. This geometry results from the thickening or thinning of a unit at the expense of adjacent units. Lithostratigraphic zones, especially the lithophysal zones, and subzones such as the vitrophyres result from the welding and cooling history of this deposit (Buesch and others, 1996). Understanding how these units vary in thickness within the modeled area, and in the area surrounding the model, can provide bounding conditions for the layout of the ESF and potential repository. The Calico Hills Formation and Prow Pass Tuff, which are included in parts of various thermal-mechanical and hydrogeologic units (table 2), form part of the geologic barrier at Yucca Mountain (Montazer and Wilson, 1984). These formations thicken from west to east across the modeled area, but there are variations in thickness of individual units in these formations (Moyer and Geslin, 1995) that should 
be modeled because they might affect how a geologic barrier works.

A change in the strike of units occurs near Drill Hole Wash and forms an apparent broad, asymmetric, southeast plunging syncline in the model (Appendix 5). This change in strike has been discussed by several authors (Spengler and Rosenbaum, 1980; and Scott and others, 1984), but separating the effects of structural folding from thickness changes of lithostratigraphic units has been problematic. The three-dimensional model provides important insight to this problem, even though borehole control on the thickness and structure contours for model units, especially those below the base of Tptrn, is limited in the area north of Drill Hole Wash. Many model units thin to the northeast of the area near Drill Hole Wash and WT\#18. For each model unit, there are variations in the position of the apparent synclinal axis, amount of change in strike of the apparent synclinal limbs, and width of the area across which the change in strike occurs (table 8; Appendix 5). The model indicates the greatest amount of change in the strike of units occurs between the bases of model units Tptrn and Tptpul (table 8; appendices $5 \mathrm{~g}$ and $5 \mathrm{~h}$ ). The model also shows that post-Topopah Spring Tuff units and the Tptrn dip to the south-southeast whereas the units below model unit Tptpul dip to the southsouthwest (Appendix 5). This change in dip direction to the southwest has not been previously recognized.

The northeastward thinning and changes in strike and dip of zones in the Topopah Spring Tuff, as shown by the model, probably indicate the Topopah Spring Tuff onlaps a paleotopographic high northeast of the modeled area. This interpretation does not preclude post-Topopah Spring Tuff folding or faulting that contributes to the change in strike and dip of units near or northeast of Drill Hole Wash. There is an approximate change of $45^{\circ}$ in strike of the Tiva Canyon Tuff across Drill Hole Wash (table 8; Appendix 5); however, paleomagnetic data in the Yucca Mountain Tuff from seven samples near and northwest of Drill Hole Wash show less than $6^{\circ}$ of vertical axis rotation (Hudson and Sawyer, 1994). Sections measured in post-Topopah Spring Tuff rocks from the northern area are currently being evaluated and will be included in future models to help constrain the possibilities of paleotopographic or structural causes for the changes in strike and dip of units in this apparent syncline. Future models can further constrain the thickness changes of units and the amount of change in structure contours by modeling the separation across the northern part of the Bow Ridge fault and expanding the modeled area to include areas north of Yucca Wash and east into Midway Valley and to Fortymile Wash.

A small area of Exile Hill has been modeled east of the Bow Ridge fault to include the north portal and ramp of the Exploratory Studies Facility (fig. 1). The main difference in the modeled geology of Exile Hill from previous cross sections is that the dips of lithostratigraphic units flatten from $10^{\circ}$ on the east side of the hill near the north portal to $3^{\circ}$ near the Bow Ridge fault on the west whereas dips in previous cross sections are $10.5^{\circ}$ across the hill. The base of the Tiva Canyon Tuff in the hanging wall of the Bow Ridge fault is modeled with a dip of $11^{\circ}$ near the fault whereas a dip of $16^{\circ}$ was

Table 8. Approximate changes in position of apparent synclinal axis, amount of change in strike of limbs, and width of area across which the change in strike occurs for various model units

\begin{tabular}{|c|c|c|c|}
\hline Model unit & Definition and alignment of apparent synclinal axis & $\begin{array}{l}\text { Amount of } \\
\text { change in } \\
\text { strike of limbs } \\
\left.\text { ( }{ }^{\circ}\right)\end{array}$ & $\begin{array}{c}\text { Width of area } \\
\text { (ft) }\end{array}$ \\
\hline Tpcun \& Tpcpv & Poorly defined, aligned with Drill Hole Wash & 45 & 10,000 \\
\hline Tpy, Tpbt3 \& Tpp & Moderately defined, approximately aligned with boreholes G-2 and WT\#14 & 45 to 48 & 7,000 \\
\hline Tptrv \& Tptrn & Well defined, approximately aligned with boreholes G-2 and WT\#14 & 60 to 65 & 5,000 \\
\hline Tptpul & Well defined, approximately aligned with boreholes G-2 and WT\#14 & 110 & 4,000 \\
\hline $\begin{array}{l}\text { Tptpln, Tptpv3 \& } \\
\text { Tptpv1\&2 }\end{array}$ & Moderately well defined, aligned with Drill Hole Wash & 120 to 130 & 6,000 to 8,000 \\
\hline Tac \& Tcp & Well defined, aligned with boreholes G-2 and WT\#14 & 110 & 4,000 to 6,000 \\
\hline
\end{tabular}


projected to the fault for units near the top of the Tiva Canyon Tuff in Buesch and others (1994). Changing the dip geometry results in the modeled vertical separation of $330 \mathrm{ft}$ across the Bow Ridge fault (table 5) whereas $385 \pm 28 \mathrm{ft}$ was calculated by Buesch and others (1994). Given the poorly, constrained geology near Exile Hill, both estimates of vertical separation are compatible with the available data, and $330 \mathrm{ft}$ is a minimum and $385 \pm 28 \mathrm{ft}$ a maximum.

Separation across the modeled Ghost Dance fault (figs. 1 and 2) is locally 1 to 2 times, but typically less than 1.5 times, the amount of separation measured on individual strands of the fault (Scott and Bonk, 1984; Spengler and others, 1993, 1994; and R. Spengler, written commun., 1994). In the model, separation on the subblock-bounding Ghost Dance fault is the net separation across the fault system. The separation used in model version YMP.R2.0 is a product of modeling for the past two years. Modeling efforts began with YMP.R0 where separations were based on the $1: 12,000$ scale map of Scott and Bonk (1984). Refinement of the separations continued with models YMP.R1.0 and YMP.R1.1 and the inclusion of preliminary data from the detailed mapping (A. Braun, SAIC-USGS, written commun., 1994). Separations in YMP.R2.0 were determined primarily by projecting the surfaces of model lithostratigraphic units to the fault, and flattening of dips on model units near the fault was based only on regional surface trends, although approximately horizontal dips are locally mapped within the fault system (Spengler and others, 1993, 1994; and R. Spengler, written commun., 1994).

As modeling progressed from version YMP.R0 to YMP.R2.0, it became clear that reliance on the separations measured at the surface resulted in significant and probably unrealistic changes in the surfaces of deeper units. The assumption that separation along dip is constant simplifies the modeling and averages the separation for all units along the dip, but may be one of the reasons that separations measured in the Tiva Canyon Tuff are overestimated in the model. The difficulty in establishing an average constant dip implies that there may be more separation across the fault system at depth, and this can be accommodated by additional individual faults or a long history of activity on the fault system prior to $12.7 \mathrm{Ma}$, the age of the Tiva Canyon Tuff. The prospect that faults are either not mapped at the surface or are concealed by the Tiva Canyon Tuff is supported by seismic reflection data that extends from west of WT-2 to east of UZ\#16 (Daley and others, 1994).

The model shows units on the west side of the Ghost Dance fault have structural low areas near the junction of the Ghost Dance and Abandoned Wash faults, near the projection of the Ghost Dance fault with the Drill Hole Wash fault, and a few units have low areas near the intersections both faults (Appendix 5). Position of the structural lows shift from the southern end of the fault for the Tiva Canyon Tuff to the northern end for the Topopah Spring Tuff. For model units Tpy, Tpbt3, Tpp, and Tptrv, there are two low areas, each at the south and north end of the fault, and Tpbt 3 is the lowest unit where the lowest point is near the southern end of the fault (Appendix 5). With increasing depth in the Topopah Spring Tuff, the difference in elevation at the base of each model unit between the south and north ends of the Ghost Dance fault increases from about $150 \mathrm{ft}$ for the upper units to $300 \mathrm{ft}$ for the lower units (Appendix 5). The occurrence of structural low areas on the west side of the Ghost Dance fault near the intersections of large northeast and northwest striking faults, and the changes in the location and size of the low area for different model units have not been previously described. The influence of the structural low areas in hydrologic models of matrix or fracture flow is not known, but these low areas might locally promote lateral flow, change direction of lateral flow, or act as delivery areas to flow in fracture systems.

\section{Application of the Model to Small-Scale Geometric Relations}

The site-scale three-dimensional lithostratigraphic model YMP.R2.0 can be used to identify areas with problematic small-scale geometric relations. These areas are centered around two- and threeborehole complexes where small-scale variations in unit thickness and elevation changes are represented, and this contrasts with areas where data are far apart and small-scale variations are smoothed out. Problematic areas are initially identified during hand-drawn map construction and are identified in the model by perturbations in structure contour maps. Small-scale variations in unit thickness and altitude changes could relate to faulting or irregular paleotopography on a geomorphic surface or contact of a lithostratigraphic zone in a welded tuff. Caution must be taken not to overinterpret small-scale features in areas of complex faulting because the site-scale model has simplified the geometric relations, as shown by the number of faults in the ancillary model of fault geometry. Given this caveat of not overinterpreting small-scale features, examples from the UZ-N31 and UZ-N32, and UZ-N53, UZ-N54, and UZ-N55 borehole complexes illustrate how small-scale variations in unit thickness can be examined in the context of the site-scale model, and how understanding the detailed stratigraphic relation in 
borehole complexes can be used to guide the modeling effort.

Boreholes UZ-N31 and UZ-N32 penetrate model units from Tpcun to the uppermost part of Tptrn and are near the Ghost Dance and Sundance fault systems, but no faults have been mapped in the immediate vicinity of these boreholes. At this location, model unit Tpy consists only of lithostratigraphic unit Tpbt4, and model unit Tptrv is divided into lithostratigraphic units Tpbt 2 and Tptv2+3. Strikes and dips of model units near the boreholes, which are calculated from the structure contours (Appendix 5a to 5f), are approximately $\mathrm{N} 0^{\circ} \mathrm{W} 5.7^{\circ} \mathrm{E}$ for units down to Tpp and $\mathrm{N} 6^{\circ} \mathrm{W} 5.4^{\circ} \mathrm{E}$ for Tptrv. Local perturbations from the regional structure contours occur for most units near the boreholes (fig. 9a). Based on the regional strike of units, the cross section through these boreholes results in apparent dips of the units (fig. 9b). In comparison to UZ-N31, units in UZ-N32 are thicker by as much as $4.2 \mathrm{ft}$, except Tpcpv, which is $0.9 \mathrm{ft}$ thinner. Contacts can be projected from UZ-N31 to UZ-N32 using the calculated regional strike and dip of $N 0^{\circ} \mathrm{W} 5.7^{\circ} \mathrm{E}$, and the assumption that units have uniform thickness for the $47.7 \mathrm{ft}$ of projection. Projected contacts (ball ticks in fig. $9 \mathrm{~b}$ ) are close to contacts in the borehole, thereby, confirming the modeled strikes and dips approximate the true attitude of the units. In the model, only the base of Tpbt 3 corresponds to the projected contact, whereas Tpcun, Tpcpv, and Tpy are above the projected contacts by as much as $4.6 \mathrm{ft}$, and Tpp and Tptrv are below the projected contacts by as much as $7.2 \mathrm{ft}$. The discrepancy between contact altitudes in the model, based on borehole data, and those projected by the simple assumptions can probably be accommodated by paleotopographic effects. No slickensides were observed in the core from either borehole, therefore there is no direct evidence for faulting. Lack of a systematic sense of vertical separation appears to preclude a dip-slip fault between the boreholes, but a strike-slip fault cannot be dismissed, especially given the documented strike-slip offset on some of the nearby faults (Spengler and others, 1994).

Geometric relations in boreholes USW UZ-N53, UZ-N54, and UZ-N55 illustrate the use of the model as a regional context for evaluating the variation in stratigraphic thicknesses. In these boreholes, model unit Tpy consists of lithostratigraphic units Tpy and Tpbt4, and there is no Tpp. Model unit Tptrv is divided into lithostratigraphic units Tpbt2 and Tptv2+3, and the crystal-rich vitrophyre of the Topopah Spring Tuff occurs only in UZ-N55. In UZ-N53 and UZ-N54, the thickness of model lithostratigraphic units, including units not specifically modeled (table 2), differ by less than $1 \mathrm{ft}$ and less than $2 \mathrm{ft}$ for Tptrv $2+3$ (fig. 10a).
Compared to UZ-N53 and UZ-N54, units Tpcpv and Tpy in UZ-N55 are slightly thicker, whereas Tpbt3, Tpbt2, and Tptrv2+3 are thinner (fig. 10a). Thus, the model and lithostratigraphic units are fairly uniform in the three boreholes with thickness variations of less than $4.7 \mathrm{ft}$. The exception to this uniformity is in UZ-N55, where the combined lithostratigraphic units of Tpbt 2 and Tpbt 3 are as much as $22.0 \mathrm{ft}$ thinner than in the other two boreholes (fig. 10a). This local change in thickness could represent a channel incised into Tpbt2 and Tpbt 3 that was filled by the superjacent units. Alternatively, a fault could cut part of the section in UZ-N55, but no slickensides or breccia have been observed in the core. If a fault intersects the borehole, then it probably has a normal-slip component indicated by the omission of section. There are differences in the thickness of all units in UZ-N55 compared to the other two boreholes, therefore, a strike-slip fault through UZ-N55 or between UZ-N55 and the other boreholes cannot be ruled out. The possible causes of the differences in unit thicknesses, paleotopography versus fault, can probably be differentiated by a detailed examination of individual beds in Tpbt 2 and Tpbt 3 to establish which beds occur in all boreholes and which ones do not.

Geometric relations in boreholes USW UZ-N53, UZ-N54, and UZ-N55 also illustrate how detailed relations show inferred structures that are not represented in the lithostratigraphic or ancillary models. Strikes and dips of model units near the boreholes, which are calculated from the structure contours (Appendix 5), are approximately $\mathrm{N} 0^{\circ} \mathrm{W} 4.6^{\circ} \mathrm{E}$ for units down to Tptrv. Local perturbations from the regional structure contours occur for most units near the boreholes (fig. 10b). Given the calculated strike and dip of $\mathrm{NO}^{\circ} \mathrm{W}$ $4.6^{\circ} \mathrm{E}$, the elevation of contacts in UZ-N54 are lower than predicted compared to UZ-N53. Assuming a strike of $\mathrm{N} 0^{\circ} \mathrm{W}$, a calculated local dip for contacts between these boreholes would be $19.6^{\circ} \mathrm{E}$. This calculated local dip differs from the gently dipping lithostratigraphic units in the boreholes (D. Buesch, nonpublished data). There is no direct evidence to indicate whether the differences in dips result from paleotopography or faulting, but a fault is probably likely based on the similarity in observed and calculated regional dips and the consistency in thicknesses of lithostratigraphic units between these two boreholes.

The area near boreholes UZ-N53, UZ-N54, and UZ-N55 is located in one of the imbricate fault zones described by Scott (1990), and illustrates one of the limitations of not modeling more faults in these complex areas. In complexly faulted areas, the regional strike and dip might not represent a lithostratigraphic attitude, but an averaged structural surface that consists 

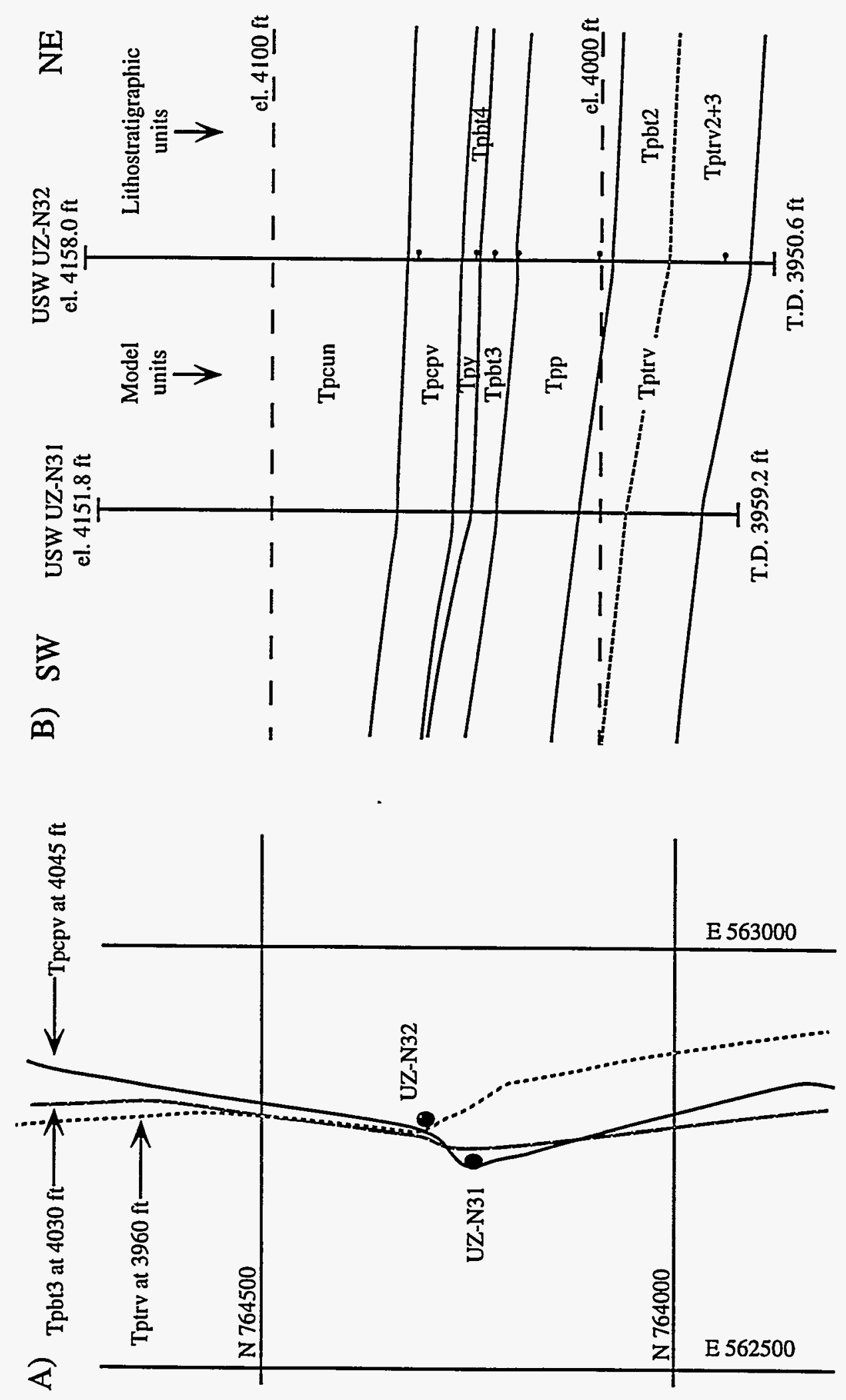

Figure 9. Structure contour map of three surfaces near boreholes UZ-N31 and UZ-N32 (A), and cross section through these boreholes (B). Nevada State Coordinates are in feet. 


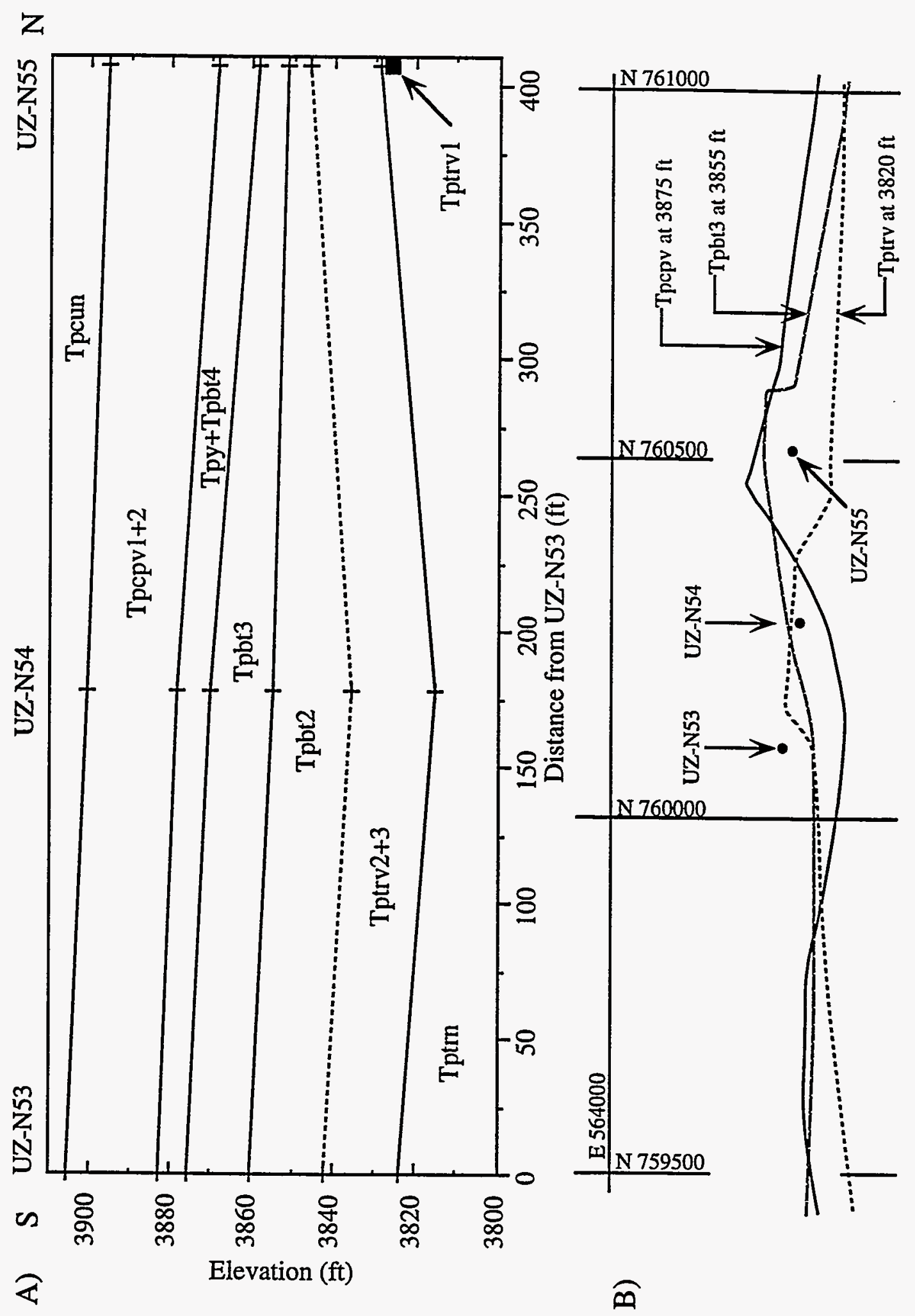

Figure 10. Vertically exaggerated fence diagram of thickness variations between boreholes UZ-N53, UZ-N54, and UZ-N55 (A), and structure contours of three surfaces near the boreholes (B). Nevada State Coordinates are in feet. 
of multiple tilted subblocks. In the vicinity of these boreholes, there are two to four faults, which could have $40 \mathrm{ft}$ to more than $130 \mathrm{ft}$ of vertical separation, that are not represented in the structure contour maps in Appendix 5 (fig. 3; tables 5 and 6). On the ridges surrounding these boreholes, dips on foliation in the Tiva Canyon Tuff vary from $14^{\circ} \mathrm{E}$ to $33^{\circ} \mathrm{E}$ (Scott and Bonk, 1984). Comparing the average dip of $4.6^{\circ} \mathrm{E}$ from the lithostratigraphic model to a calculated average dip, which is constructed using the four faults with a net separation of $130 \mathrm{ft}$ that are in the ancillary model and an average dip of $20^{\circ} \mathrm{E}$ for lithostratigraphic units, the resulting geometry indicates that the ancillary model does not contain enough faults to accommodate the regional dip in the lithostratigraphic model. The inference that this area near the UZ-N borehole complex has more faults than previously recognized is based on the above geometric exercise, the inferred fault between UZ-N53 and UZ-N54, the possible fault in UZ-N55, and the possibility of a strike-slip fault that juxtaposes sections of different thickness in UZ-N55 compared to the other two boreholes in this complex.

\section{Application of the Model to Project-Level Activities}

There are direct and indirect applications of this lithostratigraphic synthesis model to site characterization, process modeling, performance assessment, and engineering activities. Direct uses for site characterization activities include the (1) compilation of lithostratigraphic and structural data in a systematic threedimensional framework, (2) ease in expanding the model with additional lithostratigraphic units and faults, (3) addition of fracture network data in selected areas with the development of detailed subsidiary models, and (4) evaluation of geometric relations with respect to future site characterization tests. Investigators at Lawrence Berkeley Laboratory have used a previous version of this model for comparison with, and identification of, imaged surfaces in seismic reflection and refraction studies (Daley and others, 1994). Design engineers of the ESF and potential repository directly import the model as a preliminary framework for the positioning of ramps and drifts. To demonstrate the use of the model for engineering design purposes, a non-QA volume model of the ESF is included on the tape as file M, R2 (R. Elayer, YMP Management and Operations, written commun., 1994). The surfacebased maps can be easily imported into other software such as "EarthVision" used by DOE.

As the correlation of lithostratigraphic, thermalmechanical, and hydrologic units increases, the indi- rect uses of this model also increases. The surfaces in this lithostratigraphic model can be used as geometric bounding conditions for thermal-mechanical, and hydrologic properties used in process modeling, but for which there are only limited laboratory data from boreholes. Most process models and performance assessment models that use finite-element and finitedifference methods can directly import the surfacebased maps. One of the indirect uses of the lithostratigraphic model is the three-dimensional site-scale hydrologic model for the unsaturated zone that has been developed at Lawrence Berkeley Laboratory in conjunction with the U.S. Geological Survey (Wittwer and others, 1992; Bodvarsson and others, 1994).

YMP.R2.0 is a site-scale model that was developed from widely distributed boreholes with input of structural data from the 1:12,000 scale map of Scott and Bonk (1984). The LYNX software has the capability of storing data that represent a wide range of scales and it can display relations in the model that vary from $1: 12,000$ or more, to $1: 1$ or less. With the ability to zoom in to examine areas as small as one square foot, great care must be taken not to overinterpret the geometry in the model, or to lose perspective of the number of assumptions, simplifications, and limitations of the input data and model (Appendix 2).

\section{CONCLUSIONS}

This surface-based model, version YMP.R2.0, (1) is built on a database of 75 boreholes including lithostratigraphic contacts and fault intersections in boreholes, (2) permanently stores the data and the modeled surfaces, and (3) displays this information in a three-dimensional format. The model is a product of a complex set of data that is linked spatially into a preliminary, geometrically consistent three-dimensional framework. Altering one or more pieces of these data or modeled surfaces can affect the integrity of the model.

The Lynx surface-handling techniques used in model YMP.R2.0 includes (1) linear interpolation, (2) subtraction or addition of $z$ values, and (3) intersection of surfaces such as faults and structure contours as time-saving tools. Visualization of surfaces during construction provides interactive editing and rapid feedback for interpreting the results of surface handling. Two advantages of using surface handling in the creation of this model include the relative ease of updating and ready exportation of triangulated maps to other software packages. One disadvantage of using the surface-based model is the extra step required to convert the surfaces into volumes to allow volumetric and data analysis. 
All data used in the model are $Q$ status, except for the supporting data from the pre-1989 boreholes. More than half of the boreholes and all of the deepest boreholes are currently classified with a non- $Q$ status. If the decision is made to accept this supporting data into $Q$ status, then the project could use this model in developing documents for license application for the potential repository. The design engineers could ultimately use the model for potential repository layout and mining calculations that depend on an understanding of the relation of lithologic units and faults. Process models and performance assessment models would also have a firm geometric foundation against which the models can be baselined, and from which various scenarios can be tested.

\section{REFERENCES CITED}

\section{Borehole references are cited separately in Appendix 3.}

Bates, R.L., and Jackson, J.A., 1987, Glossary of Geology: Alexandria, Virginia, American Geological Institute, $788 \mathrm{p}$.

Bodvarsson, G., Chen, G., and Wittwer, C., 1994, Preliminary analysis of three-dimensional moisture flow within Yucca Mountain, Nevada: in Proceedings of the Fifth International High-Level Radioactive Waste Management Conference, American Nuclear Society, v. 4, p. 2038-2047.

Broxton, D.E., Warren, R.G., Hagan, R.C., and Luedemann, Gary, 1986, Chemistry of diagenetically altered tuffs at a potential nuclear-waste repository, Yucca Mountain, Nye County, Nevada: Los Alamos National Laboratory Report LA-10802-MS, 160 p.

Broxton, D.E., Chipera, S.J., Byers, E.M., Jr., and Rautman, C.A., 1993, Geologic evaluation of six nonwelded tuff sites in the vicinity of Yucca Mountain, Nevada, for a surface-based test facility for the Yucca Mountain Project: Los Alamos National Laboratory Report LA-12542-MS, 83 p.

Buesch, D.C., Dickerson, R.P., Drake, R.M., and Spengler, R.W., 1994, Integrated geology and preliminary cross section along the north ramp of the Exploratory Studies Facility, Yucca Mountain: in Proceedings of the Fifth Annual International High-Level Radioactive Waste Management Conference, American Nuclear Society, v. 2, p. 1055-1065.

Buesch, D.C., Nelson, J.E., Dickerson, R.P., and Spengler, R.W., 1993a, Development of 3-D lithostratigraphic and confidence models at Yucca Mountain, Nevada: in Proceedings of the Fourth International High-Level Radioactive Waste Management Conference, American Nuclear Society, v. 1, p. 943-948.
Buesch, D.C., Spengler, R.W., Nelson, J.E., and Dickerson, R.P., 1993b, Three-dimensional lithostratigraphic model at Yucca Mountain, Nevada: A framework for fiuid transport modeling and engineering design: in Site Characterization and Model Validation-Focus '93', American Nuclear Society, p. 226-231.

Buesch, D.C., Spengler, R.W., Moyer, T.C., and Geslin, J.K., in press, Proposed stratigraphic nomenclature and macroscopic identification of lithostratigraphic units of the Paintbrush Group exposed at Yucca Mountain, Nevada: U.S. Geological Survey Open-File Report 94-469.

Byers, F.M., Jr., Carr, M.J., Christiansen, R.L., Lipman, P.W., Orkild, P.P., and Quinlivan, W.D., 1976a, Geologic map of the Timber Mountain caldera area, Nye County, Nevada: U.S. Geological Survey Miscellaneous Investigations Map I-891, Scale 1:48,000.

Byers, F.M., Jr., Carr, M.J., Orkild, P.P., Quinlivan, W.D., and Sargent, K.A., 1976b, Volcanic suites and related cauldrons of the Timber Mountain-Oasis Valley caldera complex, southern Nevada: U.S. Geological Survey Professional Paper 919, 70 p.

Byers, F.M., Jr., and Moore, L.M., 1987, Petrographic variation of the Topopah Spring Tuff matrix within and between cored drill holes, Yucca Mountain, Nevada: Los Alamos National Laboratory Report LA-10901-MS, 72 p.

Carr, M.D., 1984, Regional structural setting of Yucca Mountain, southwestern Nevada, and late Cenozoic rates of tectonic activity in part of the southwestern Great Basin, Nevada and California: U.S. Geological Survey Open-File Report 84-854, 109 p.

Carr, M.D., Geology of drill hole UE-25p \#1-A test hole into pre-Tertiary rocks near Yucca Mountain, southern Nevada-Menlo Park, Calif: U.S. Geological Survey, 1986.

Carr, M.D., 1990, Styles of extension in the Nevada Test Site region, southern Walker Lane Belt; An integration of volcano-tectonic and detachment fault models: in Wernicke, B.P., ed., basin and range extensional tectonics near the latitude of Las Vegas, Nevada: Boulder, Colorado, Geological Society of America Memoir 176, p. 283-303.

Christiansen, R.L., Lipman, P.W., Carr, M.J., Byers, F.M., Jr., Orkild, P.P., and Sargent, K.A., 1977, The Timber Mountain-Oasis Valley caldera complex of southern Nevada: Geological Society of America Bulletin, v. 88, p. 943-959.

Daley, T.M., Majer, E.L., and Karageorgi, E., 1994, Combined analysis of surface reflection imaging and vertical seismic profiling at Yucca Mountain, Nevada: Lawrence Berkeley Laboratory Report LBL-36467.

Davis, J.C., 1986, Statistics and data analysis in geology: New York, John Wiley \& Sons, p. 358-361, 364. 
Conference, American Nuclear Society, v. 1, p. 653-659.

Spengler, R.W., Braun, C.A., Martin, L.G., and Weisenberg, C.W., 1994, The Sundance fault: A newly recognized shear zone at Yucca Mountain, Nevada: U.S. Geological Survey Open-File Report 94-049, 11 p. Spengler, R.W., and Fox, K.F., Jr., 1989, Stratigraphic and structural framework of Yucca Mountain, Nevada: Radioactive Waste Management and the Nuclear Fuel Cycle, v. 13, no. 1-4, p. 21-36.

Spengler, R.W., and Rosenbaum, J.G., 1980, Preliminary interpretations of geologic results obtained from boreholes UE-25a\#4, \#5, \#6, and \#7, Yucca Mountain, Nevada Test Site: U.S. Geological Survey Open-File Report 80-929, 33 p. (DTN: GS900908314213.002).
Wittwer, C.S., Bodvarsson, G.S., Chornack, M.P., Flint, L.E., Lewis, B.D., Spengler, R.W., and Rautman, C.A., 1992, Design of a three-dimensional site-scale model for the unsaturated zone at Yucca Mountain, Nevada: in Proceedings of the Third International High-Level Radioactive Waste Management Conference, American Nuclear Society, v. 1, p. 263-271.

NOTE: Parenthesized numbers following each cited reference are for U.S. Department of Energy OCRWM Records Management purposes only and should not be used when ordering the publication. 
APPENDICES 


\section{APPENDIX 1. ADDITIONS AND UPDATES FROM MODEL VERSION YMP.R1.1}

\section{ADDITIONS}

\section{Borehole Data Base}

a. Lithostratigraphic units are individually entered in the data base. The new data base contrasts with that of YMP.R1.1 where only the contacts for the modeled units were included.

b. Location and lithostratigraphic units in borehole USW SD-9.

c. Location and lithostratigraphic units in borehole USW SD-12.

d. Deviation surveys of 26 boreholes referenced in appendix 3.

\section{Geology}

a. Geology in a $1,000 \mathrm{ft}$ by $1,000 \mathrm{ft}$ area of Exile Hill east of the Bow Ridge fault that includes the portal and main drift of the Exploratory Studies Facility.

b. New surfaces include the base of the Calico Hills Formation and Prow Pass Tuff.

c. Summary of assumptions and sources of error (appendix 2).

d. A non- $Q$ volume model of the Exploratory Studies Facility for demonstration purposes.

\section{UPDATES}

\section{Borehole Data Base}

a. Lithostratigraphic contacts in UE-25 NRG\#4 and UE-25 NRG\#5.

\section{Geology}

a. Modification of structure contour maps to include new information from SD-9, SD-12, NRG\#4, and NRG\#5. Most editorial changes of structure contours are near this new information in model subblocks A and D.

b. Adjusted position and dip of the Bow Ridge fault based on borehole intercepts and maps (Buesch and others, 1994). 


\section{APPENDIX 2. ASSUMPTIONS AND POTENTIAL SOURCES OF ERROR IN THE MODEL}

This appendix of assumptions and sources of errors in the data and model is a summary listing, and more detailed discussions are in the respective parts of the text. Assumptions made prior to and during modeling can effect how the modeling is done and the final geometry that is portrayed. Many sources of error are inherent in the data whereas some result from how a procedure was implemented. The assumptions and methods used to develop data are based on sound geologic principles and modeling practices.

\section{ASSUMPTIONS}

1. Combination of lithostratigraphic units into a single model unit does not portray thickness variations of units, or lateral pinchout of units such as the Yucca Mountain Tuff that is included in the model unit Tpy.

2. Model lithostratigraphic units reflect the revised stratigraphic nomenclature, but model units were chosen such that previously identified units could be included without reexamining all original source data. For example, the inclusion of the crystal-rich lithophysal zone with the crystal-poor upper lithophysal zones to form the Tptpul model unit, thereby emphasizing the lithophysae content.

3. Contacts between lithostratigraphic units are assumed to be conformable with one another and reflect the general stratiform geometry of Yucca Mountain. Local exceptions occur where units pinch out or are faulted.

4. Linear interpolation is used in creation of the primary structure-contour maps and isochore maps.

5. The base of the Tiva Canyon Tuff as the primary structure contour has the best control, but there are many modeling cycles for deeper units that can result in errors in the deeper surfaces. During construction of model version YMP.R1.0, a structure contour on the top of the crystal-rich vitrophyre in the Topopah Spring Tuff was constructed independent of the model. The two maps were in good agreement throughout most of the area, and where there were differences, each geometric solution was geologically reasonable.

6. The decision to only model subblock-bounding faults locally over simplifies lithostratigraphic and structural relations. Vertical separation on the modeled Ghost Dance fault represents the net separation across the entire system that is locally as much as $1,200-\mathrm{ft}$ wide.

7. Constant dip on a fault and constant vertical separation along dip, but with variable separation along strike, simplifies the modeling of faults in a uniform method, but can be a source of geometric error.

8. Constant thickness of modeled lithostratigraphic units across faults is consistent with dip-slip, but not necessarily strike-slip faults.

9. Faults dip to the west and have normal separation. No faults with apparent reverse sense of separation are modeled.

10. All faulting is post-Tiva Canyon Tuff as implied in the assumption of constant separation along dip and by not modeling concealed faults.

11. The topographic base is a digital elevation map with 20 - $\mathrm{ft}$ contour interval.

12. Surfaces are truncated by topography only and do not include erosional effects such as channels filled with alluvium. 


\section{SOURCES OF ERROR}

\section{Borehole Database}

1a. Borehole locations that are not accurate.

1b. Variable spacing of boreholes result in large distances that must be interpolated.

2. Borehole deviations that are either not correct or not included.

3a. Lithologic logs span a time period of 1979 to 1994 , and the identification of lithostratigraphic units has evolved.

3b. Source data for previous published logs from boreholes were not reexamined except where there were obvious discrepancies.

3c. Mixing of lithostratigraphic contacts in boreholes determined from core or inferred from cuttings, video camera logs, and geophysical logs.

3d. These lithostratigraphic errors do not appear to be a large source of error. Where lithologic contacts in boreholes with differing data are compared, there do not appear to be large changes in the shape of the structure contour maps.

4. Use of a formulated relative thickness for the bedded tuffs in the Paintbrush Group where the interstratified Yucca Mountain and Pah Canyon Tuffs do not occur.

5. Faults not recognized in boreholes can affect thickness of units.

\section{Faults}

1. Faults are modeled with west dips and normal separation.

2. Drafting or typographical errors on previous maps and lithologic logs.

3. Calculation of strikes and dips from maps.

4. Constant dip can result in an increase in error of position with depth.

5. Digitizing errors-Digitizing fault traces from a paper copy of Scott and Bonk (1984). A digital version was not available at the time fault traces were input. Method of digitizing can vary between individuals.

6. Method of projecting the traces to form modeled faults.

7. Registration of topographic contours on paper or digital maps with survey data on the ground surface or in boreholes.

8. Simplified structure resulting from not modeling all faults.

9. Variable scales of map and borehole data.

40 Distribution of Lithostratigraphic Units Within the Central Block of Yucca Mountain, Nevada: A Three-Dimensional Computer-Based Model, Version YMP.R2.0 


\section{Modeling}

1. Distribution of boreholes and primary structural data for faults on the $1: 12,000$ scale map of Scott and Bonk (1984) that are best used for site-scale relations. This model might not be appropriate for very detailed applications.

2. The thickness of lithostratigraphic units and position of contacts differ from the map of Scott and Bonk (1984) and borehole data. At the northwest end of model subblock D and in subblock $F$ there are very few boreholes, therefore, stratigraphic information was derived from the map of Scott and Bonk (1984).

3a. Variable spacing of boreholes and changing borehole sets for different surfaces.

3b. Deeper modeled units have less confidence in variations in thickness and position of contacts because the distribution of data in boreholes is more widely distributed than for the near surface model units.

4. Use of isochore maps that do not account for dip.

5. Subtracting isochore maps from a structure contour can result in a slightly different geometry than adding isochore to the top.

6. Thinning of points on contour lines and maps generated during modeling; this affects the triangulation network.

7. Linear interpolation used in editing structure contour maps produced from the modeling process.

8. Insertion of intermediate structure contours to control surfaces where lithostratigraphic units are thin or in structurally complex areas.

9. View dependency of surface-fault intersection lines, but experienced modelers using the LYNX software can model intersections that differ only slightly. At the scale of this model this is a very minor source of error (see 11 below).

10. Surfaces constructed from two dimensional maps do not always create an integrated three-dimensional geometry.

11. Precision in modeled surfaces and lines of intersection is modeled as a question of diminishing returns. Great precision can be attained with a large investment of resources, but precision must be balanced with the quality of available data. 


\section{APPENDIX 3. REFERENCES USED FOR DETERMINING LITHOSTRATIGRAPHIC CONTACTS IN BOREHOLES}

\section{Q-status Logging Reports}

Geslin, J.K., Moyer, T.C., and Buesch, D.C., 1995, Summary of lithostratigraphic logging of new and existing boreholes at Yucca Mountain, Nevada, August 1993 to February 1994: U.S. Geological Survey Open-File Report 94-342.

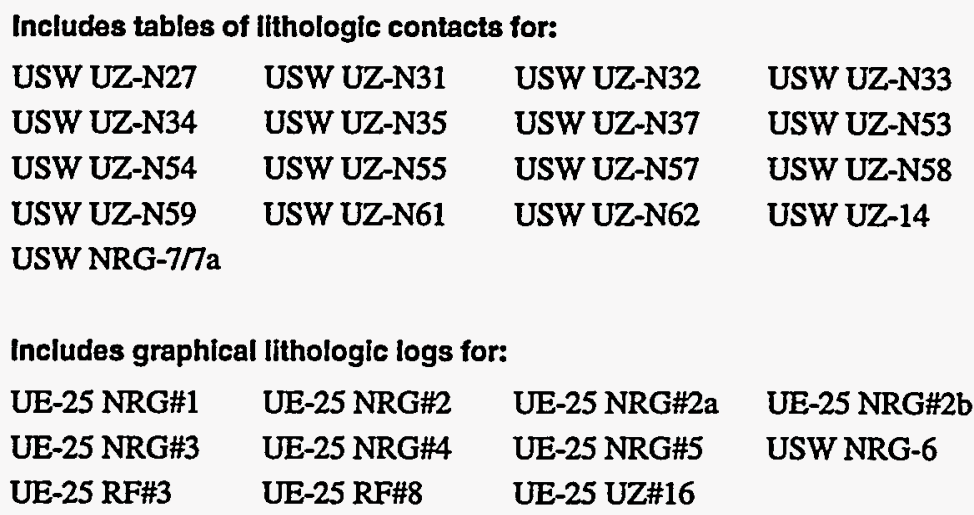

Geslin, J.K., and Moyer, T.C., 1995, Summary of lithostratigraphic logging of new and existing boreholes at Yucca Mountain, Nevada, March 1994 to June 1994: U.S. Geological Survey Open-File Report 94-451, 16 p.

Includes tables of lithologic contacts for:

$\begin{array}{llll}\text { USW UZ-N11 } & \text { USW UZ-N15 } & \text { USW UZ-N16 } & \text { USW UZ-N17 } \\ \text { USW UZ-N36 } & \text { USW UZ-N38 } & \text { USW UZ-N64 } & \text { UE-25 UZN\#63 }\end{array}$

Includes graphical lithologic logs for:

UE-25 NRG\#2c UE-25 NRG\#2d USW NRG-7/7a

Moyer, T.C., Geslin, J.K., and Buesch, D.C., 1995, Summary of lithostratigraphic logging of new and existing boreholes at Yucca Mountain, Nevada, July 1994 to November 1994: U.S. Geological Survey Open-File Report 95-102.

Includes tables of lithologic contacts for:

USW SD-9 USW SD-12 The lower part of USW UZ-14

Drill cuttings from the upper part of boreholes UE-25 NRG\#4 and NRG\#5

Includes graphical lithologic logs for:

USW SD-9 USW SD-12 USW UZ-N31 USW UZ-N32

Nonpublished tables and logs submitted to the USGS LRC in Denver.

USW G-2 Moyer, T.C., 1994, Miscellaneous Lithostratigraphic Contacts in Non-Qualified Boreholes (DTN:

GS940708314211.034)

UE-25A \#1

USW G-4 


\section{Previously Published Reports (non-Q)}

UE-25A \#1

UE-25A \#4 through A \#7

UE-25B \#1

UE-25C \#1, 2, and 3

UE-25P \#1

UE-25 UZ \#4 \& 5

UE-25 WT\#4

UE-25 WT\#6

UE-25 WT\#14
Spengler, R.W., Muller, D.C., and Livermore, R.B., 1979, Preliminary report on the geology and geophysics of drill hole UE-25A \#1, Yucca Mountain, Nevada Test Site: U.S. Geological Survey Open-File Report 79-1244, 43 p. (DTN: GS920908314211.004).

Spengler, R.W., and Rosenbaum, J.G., 1980, Preliminary interpretations of geologic results obtained from boreholes UE-25a \#4, \#5, \#6, and \#7, Yucca Mountain, Nevada Test Site: U.S. Geological Survey Open-File Report 80-929, 33 p. (DTN: GS900908314213.002).

Lobmeyer, D.H., Whitfield, M.S., Jr., Lahoud, R.R., and Bruckheimer, L., 1983, Geohydrologic data for test well UE-25b \#1(H), Nevada Test Site, Nye County, Nevada: U.S. Geological Survey Open-File Report 83-855, 48 p. (DTN: GS930408312313.004). Nelson, P.H., Muller, D.C., Schimschal, U., and Kibler, J.E., 1991, Geophysical logs and core measurements from forty boreholes at Yucca Mountain, Nevada: Map GP-1001(DTN: 920108314213.001).

Geldon, A.L., 1992, Preliminary hydrologic through C\#3 assessment of boreholes UE-25c \#1, UE-25c \#2, and UE-25c \#3, Yucca Mountain, Nye County, Nevada: U.S. Geological Survey Water-Resources Investigations Report 92-4016, 85 p. (DTN: GS930308312313.002).

Carr, M.D., Waddell, S.J., Vick, G.S., Stock, J.M., Monsen, S.A., Harris, A.G., Cork, B.W., and Byers, F.M., Jr., 1986, Geology of drill hole UE-25p \#1: A test hole into pre-Tertiary rocks near Yucca Mountain, southern Nevada: U.S. Geological Survey Open-File Report 86-175, 59-80 p. (DTN: GS930283117461.002).

Loskot, C.L., and Hammermeister, D.P., 1992, Geohydrologic data from test holes UE-25 UZ\#4 and UE-25 UZ\#5, Yucca Mountain area, Nye County, Nevada: U.S. Geologic Survey Open-File Report 90-369, 56 p. (DTN: GS921008312211.008).

Spengler, R.W., 1993, Preliminary lithology well reports: UE-25 WT\#4, USW WT-11, and UE-25 WT\#12 (DTN: GS930708314211.030). Data previously published/released in Map Report GP-1001 (DTN: GS920108314213.001) and USGS-OFR-86-46 (DTN: GS900983117475.002).

Nelson, P.H., Muller, D.C., Schimschal, U., and Kibler, J.E., 1991, Geophysical logs and core measurements from forty boreholes at Yucca Mountain, Nevada: Map GP-1001 (DTN: 920108314213.001 ).

Spengler, R.W., 1993, Preliminary lithology well report for UE-25 WT\#6 (DTN: GS930208314211.006). Data previously published/released in Map Report GP-1001 (DTN:GS920108314213.001) and USGS-OFR-86-46 (DTN: GS900983117475.002).

Nelson, P.H., Muller, D.C., Schimschal, U., and Kibler, J.E., 1991, Geophysical logs and core measurements from forty boreholes at Yucca Mountain, Nevada: Map GP-1001 (DTN: 920108314213.001).

Spengler, R.W., 1993, Preliminary lithology well report for UE-25 WT\#14 (DTN: GS931008314211.034). Data previously published/released in Map Report GP-1001 (DTN:GS920108314213.001) and USGS-OFR-86-46 (DTN: GS900983117475.002).

Nelson, P.H., Muller, D.C., Schimschal, U., and Kibler, J.E., 1991, Geophysical logs and core measurements from forty boreholes at Yucca Mountain, Nevada: Map GP-1001 (DTN: 920108314213.001). 
UE-25 WT\#16

UE-25 WT\#17

UE-25 WT\#18

USW G-1

USW G-2

USW G-3

USW G-4

USW H-1

USW H-3
Spengler, R.W., 1993, Preliminary lithology well reports for USW WT-1, WT-2, WT-7 \& WT-10, and UE-25 WT\#3, \#16, \#17, \& \#18 (DTN: GS930208314211.004). Data previously published/released in Map Report GP-1001 (DTN: GS920108314213.001) and USGS-OFR-86-46 (DTN: GS900983117475.002).

Nelson, P.H., Muller, D.C., Schimschal, U., and Kibler, J.E., 1991, Geophysical logs and core measurements from forty boreholes at Yucca Mountain, Nevada: Map GP-1001 (DTN: 920108314213.001).

Spengler, R.W., 1993, Preliminary lithology well reports for USW WT-1, WT-2, WT-7 \& WT-10, and UE-25 WT\#3, \#16, \#17, \& \#18 (DTN: GS930208314211.004). Data previously published/released in Map Report GP-1001 (DTN: GS920108314213.001) and USGS-OFR-86-46 (DTN: GS900983117475.002).

Nelson, P.H., Muller, D.C., Schimschal, U., and Kibler, J.E., 1991, Geophysical logs and core measurements from forty boreholes at Yucca Mountain, Nevada: Map GP-1001 (DTN: 920108314213.001).

Spengler, R.W., 1993, Preliminary lithology well reports for USW WT-1, WT-2, WT-7 \& WT-10, and UE-25 WT\#3, \#16, \#17, \& \#18 (DTN: GS930208314211.004). Data previously published/released in Map Report GP-1001 (DTN:GS920108314213.001) and USGS-OFR-86-46 (DTN: GS900983117475.002).

Nelson, P.H., Muller, D.C., Schimschal, U., and Kibler, J.E., 1991, Geophysical logs and core measurements from forty boreholes at Yucca Mountain, Nevada:

Map GP-1001 (DTN: 920108314213.001$).$

Spengler, R.W., Byers, F.M., Jr., Warner, J.B., 1981, Stratigraphy and structure of volcanic rocks in drill hole USW G-1, Yucca Mountain, Nye County, Nevada: U.S. Geological Survey Open-File Report 81-1349, 50 p. (DTN: GS930208314211.005).

Maldonado, F., and Koether, S.L., 1983, Stratigraphy, structure, and some petrographic features of Tertiary volcanic rocks in the USW G-2 drill hole, Yucca Mountain, Nye County, Nevada: U.S. Geological Survey Open-File Report 83-732, 83 p. (DTN: GS930208314211.008).

Scott, R.B., and Castellanos, M., 1984, Stratigraphic and structural relations of volcanic rocks in drill holes USW GU-3 and USW G-3, Yucca Mountain, Nye County, Nevada: U.S. Geological Survey Open-File Report 84-491, 121 p. (DTN: GS920908314211.002).

Spengler, R.W., and Chornack, M.P., 1984, Stratigraphic and structural characteristics of volcanic rocks in core hole USW G-4, Yucca Mountain, Nye County, Nevada, with a section on geophysical logs by Muller, D.C., and Kibler, J.E., U.S. Geological Survey Open-File Report 84-789, 77 p. (DTN: GS920908314211.003).

Rush, F.E., Thordarson, W., and Pyles, D.G., 1983, Geohydrology of test well USW H-1, Yucca Mountain, Nye County, Nevada: U.S. Geological Survey WaterResources Investigations Report 83-4032, 56 p. (DTN: GS920408312314.011).

Nelson, P.H., Muller, D.C., Schimschal, U., and Kibler, J.E., 1991, Geophysical logs and core measurements from forty boreholes at Yucca Mountain, Nevada: Map GP-1001 (DTN: 920108314213.001).

Thordarson, W., Rush, F.E., Spengler, R.W., and Waddell, S.J., 1984, Geohydrologic and drill hole data for test well USW H-3, Yucca Mountain, Nye County, Nevada:

U.S. Geological Survey Open-File Report 84-149, 28 p. (DTN: GS900908312312.001). 
USW H-4

USW H-5

USW H-6

USW UZ-1

USW UZ-13

USW UZ-6

USW UZ-7

USW WT-1

USW WT-2

USW WT-7
Whitfield, M.S., Jr., Thordarson, W., and Eshom, E.P., 1984, Geohydrologic and drill hole data for test well USW H-4, Yucca Mountain, Nye County, Nevada, with a lithologic log compiled by Spengler, R.W., 1983: U.S. Geological Survey Open-File Report 84-449, 39 p. (DTN: GS900908312312.002).

Bently, C.B., Robison, J.H., and Spengler, R.W., 1983, Geohydrologic data for test well USW H-5, Yucca Mountain area, Nye County, Nevada: U.S. Geological Survey OpenFile Report 83-853, 34 p. (DTN: GS910908312132.002).

Craig, R.W., Reed, R.L., Spengler, R.W., 1983, Geohydrologic data for test well USW H-6, Yucca Mountain area, Nye County, Nevada: U.S. Geological Survey Open-File Report 83-856, 35 p. (DTN: GS910908312132.001).

Whitfield, M.S., Thordarson, W., Hammermeister, D.P., and Warner, J.B., 1990, Drilling and geohydrologic data for test hole USW UZ-1, Yucca Mountain, Nye County, Nevada, U.S. Geological Survey Open-File Report 90-354, 40 p. (DTN:GS930608312232.016). Spengler, R.W., 1993, Preliminary lithologic log of test hole USW UZ-1 (DTN: GS930708314211.033). Data previously published/released in Whitfield and others, 1990 (DTN: GS930608312232.016).

Kume, J., and Hammermeister, D.P., 1991, Geohydrologic data from drill-bit cuttings and rotary cores from test hole USW UZ-13, Yucca Mountain area, Nye County, Nevada: U.S. Geological Survey Open-File Report 90-362, 30 p. (DTN: GS920808312232.001).

Whitfield, M.S., Cope, C.M., and Loskot, C.L., 1992, Borehole and geohydrologic data for test hole USW UZ-6, Yucca Mountain area, Nye County, Nevada: U.S. Geological Survey Open-File Report 92-28, 36 p. (DTN: GS910808312232.002).

Kume, J., and Hammermeister, D.P., 1990, Geohydrologic data from test hole USW UZ-7, Yucca Mountain area, Nye County, Nevada: U.S. Geological Survey Open-File Report 88-465, 37 p. (DTN: GS900908312232.001).

Spengler, R.W., 1993, Preliminary lithology well reports for USW WT-1, WT-2, WT-7 \& WT-10, and UE-25 WT\#3, \#16, \#17, \& \#18 (DTN: GS930208314211.004). Data previously published/released in Map Report GP-1001 (DTN:GS920108314213.001) and USGS-OFR-86-46 (DTN: GS900983117475.002).

Nelson, P.H., Muller, D.C., Schimschal, U., and Kibler, J.E., 1991, Geophysical logs and core measurements from forty boreholes at Yucca Mountain, Nevada: Map GP-1001 (DTN: 920108314213.001).

Spengler, R.W., 1993, Preliminary lithology well reports for USW WT-1, WT-2, WT-7 \& WT-10, and UE-25 WT\#3, \#16, \#17, \& \#18 (DTN: GS930208314211.004). Data previously published/released in Map Report GP-1001 (DTN: GS920108314213.001) and USGS-OFR-86-46 (DTN: GS900983117475.002).

Nelson, P.H., Muller, D.C., Schimschal, U., and Kibler, J.E., 1991, Geophysical logs and core measurements from forty boreholes at Yucca Mountain, Nevada:

Map GP-1001 (DTN: 920108314213.001).

Spengler, R.W., 1993, Preliminary lithology well reports for USW WT-1, WT-2, WT-7 \& WT-10, and UE-25 WT\#3, \#16, \#17, \& \#18 (DTN: GS930208314211.004). Data previously published/released in Map Report GP-1001 (DTN: GS920108314213.001) and USGS-OFR-86-46 (DTN: GS900983117475.002).

Nelson, P.H., Muller, D.C., Schimschal, U., and Kibler, J.E., 1991, Geophysical logs and core measurements from forty boreholes at Yucca Mountain, Nevada:

Map GP-1001 (DTN: 920108314213.001). 
Spengler, R.W., 1993, Preliminary lithology well reports for USW WT-1, WT-2, WT-7 \& WT-10, and UE-25 WT\#3, \#16, \#17, \& \#18 (DTN: GS930208314211.004). Data previously published/released in Map Report GP-1001 (DTN: GS920108314213.001) and USGS-OFR-86-46 (DTN: GS900983117475.002).

Nelson, P.H., Muller, D.C., Schimschal, U., and Kibler, J.E., 1991, Geophysical logs and core measurements from forty boreholes at Yucca Mountain, Nevada: Map GP-1001 (DTN: 920108314213.001). 


\section{APPENDIX 4. REFERENCES USED FOR NON-Q DEVIATION SURVEYS OF BOREHOLES DRILLED PRIOR TO 1989}

\begin{tabular}{ll}
\hline Borehole & \multicolumn{1}{c}{ Reference } \\
\hline UE-25a \#1 & Sperry-Sun, Inc., 8/26/78, Directional Survey Report \\
UE-25b \#1 & Eastman Whipstock, 8/3/81, Report of Sub-surface Directional Survey \\
UE-25c \#1 & Eastman Whipstock, 9/18/83, Report of Sub-surface Directional Survey \\
UE-25c \#2 & NL Sperry-Sun, Inc., 2/27/84, Report of Sub-surface Directional Survey \\
UE-25c \#3 & NL Sperry-Sun, Inc., 4/26/84, Report of Sub-surface Directional Survey \\
UE-25p \#1 & Eastman Whipstock, 5/1/83, Report of Sub-surface Directional Survey \\
USW G-1 & Eastman Whipstock, 4/29/80, Report of Sub-surface Directional Survey \\
USW G-2 & Eastman Whipstock, 10/13/81, Report of Sub-surface Directional Survey \\
USW GU-3 & Eastman Whipstock, 5/18/82, Report of Sub-surface Directional Survey \\
USW G-4 & Eastman Whipstock, 11/7/82, Report of Sub-surface Directional Survey \\
USW H-1 & Eastman Whipstock, 11/22/80, Report of Sub-surface Directional Survey \\
USW H-3 & Eastman Whipstock, 2/3/82, Report of Sub-surface Directional Survey \\
USW H-4 & Eastman Whipstock, 4/30/82, Report of Sub-surface Directional Survey \\
USW H-5 & Eastman Whipstock, 6/23/82, Report of Sub-surface Directional Survey \\
USW H-6 & Eastman Whipstock, 10/8/82, Report of Sub-surface Directional Survey \\
USW WT-1 & Eastman Whipstock, 5/16/83, Report of Sub-surface Directional Survey \\
USW WT-1 & Eastman Whipstock, 7/12/83, Report of Sub-surface Directional Survey \\
UE-25 WT\#4 & Eastman Whipstock, 6/2/83, Report of Sub-surface Directional Survey \\
UE-25 WT\#5 & Eastman Whipstock, 6/10/83, Report of Sub-surface Directional Survey \\
UE-25 WT\#6 & Eastman Whipstock, 6/27/83, Report of Sub-surface Directional Survey \\
USW WT-7 & Eastman Whipstock, 7/23/83, Report of Sub-surface Directional Survey \\
USW WT-10 & Eastman Whipstock, 7/30/83, Report of Sub-surface Directional Survey \\
UE-25 WT\#16 & NL Sperry-Sun, Inc., 11/7/83, Report of Sub-surface Directional Survey \\
UE-25 WT\#17 & NL Sperry-Sun, Inc., 10/26/83, Report of Sub-surface Directional Survey \\
UE-25 WT\#18 & NL Sperry-Sun, Inc., 5/5/83, Report of Sub-surface Directional Survey \\
USW UZ-6 & NL Sperry-Sun, Inc., 8/29/83, Report of Sub-surface Directional Survey \\
\hline &
\end{tabular}




\section{APPENDIX 5. STRUCTURE CONTOUR MAPS ON THE BASE OF MODELED LITHOSTRATIGRAPHIC UNITS}




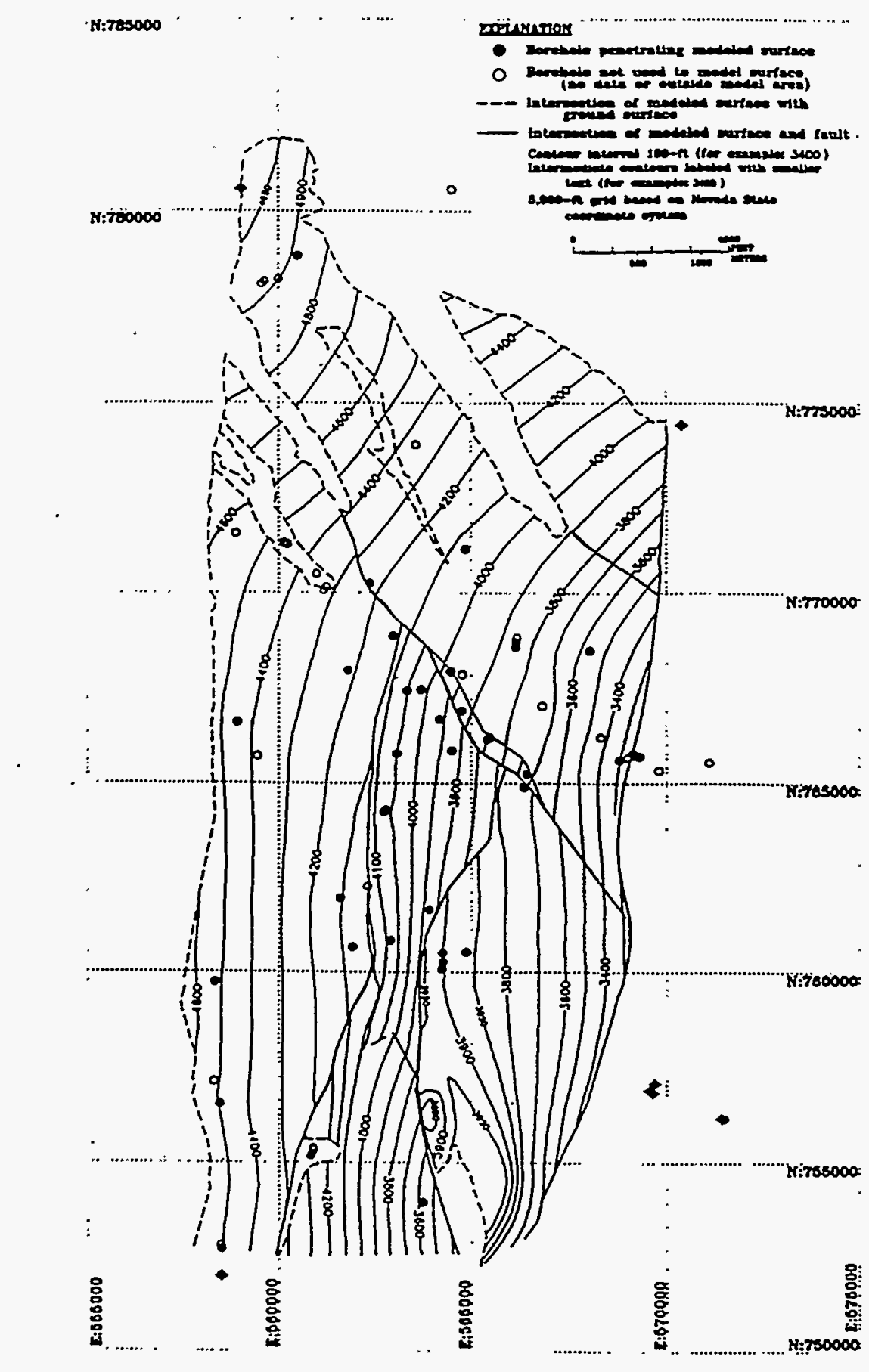

Appendix 5a. Structure contour map of the base of the model Tiva Canyon Tuff undifferentiated devitrified unit (Tpcun). 


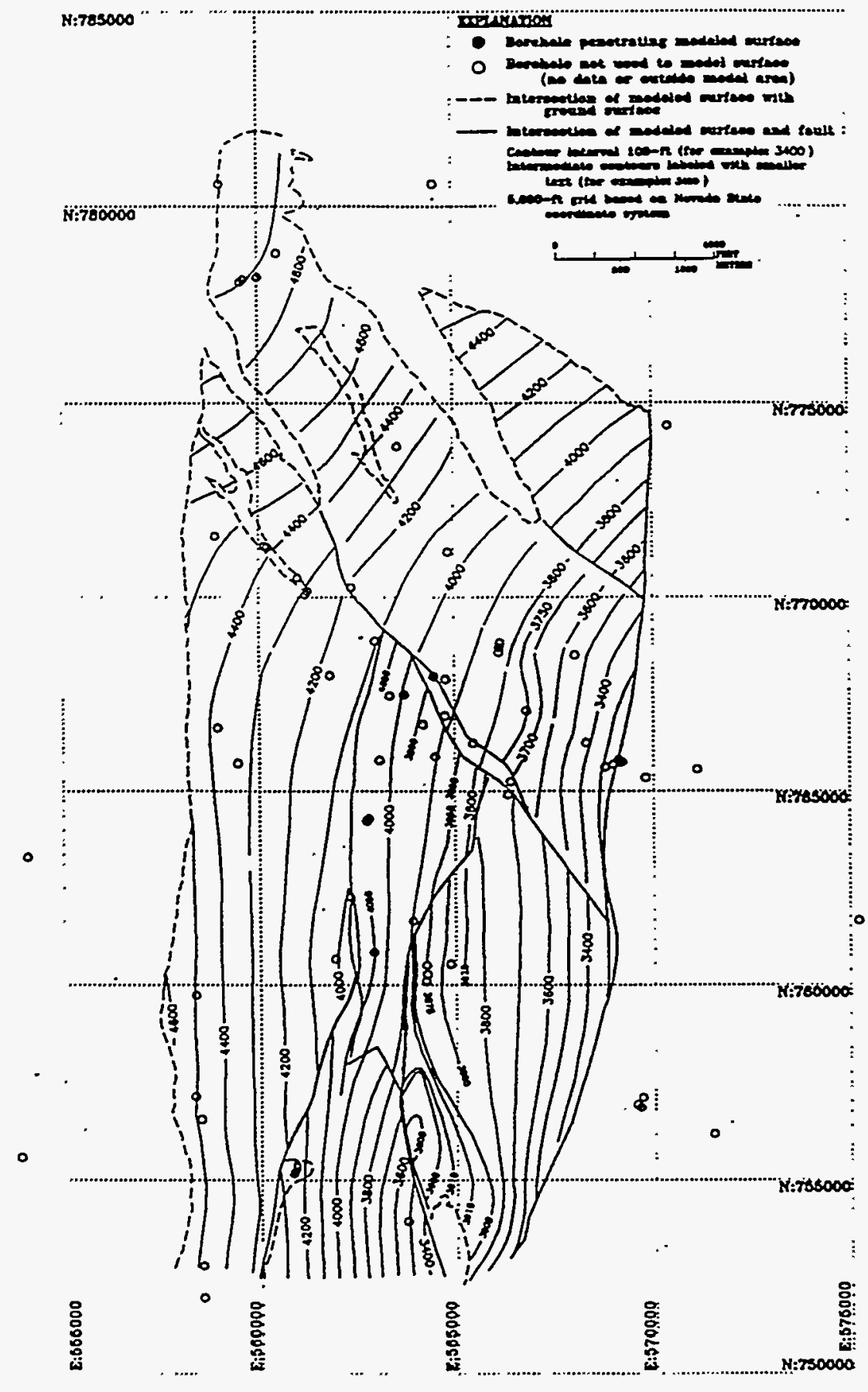

Appendix 5b. Structure contour map of the base of the model Tiva Canyon Tuff crystal-poor nonwelded to moderately welded vitric unit (Tpcpv). 


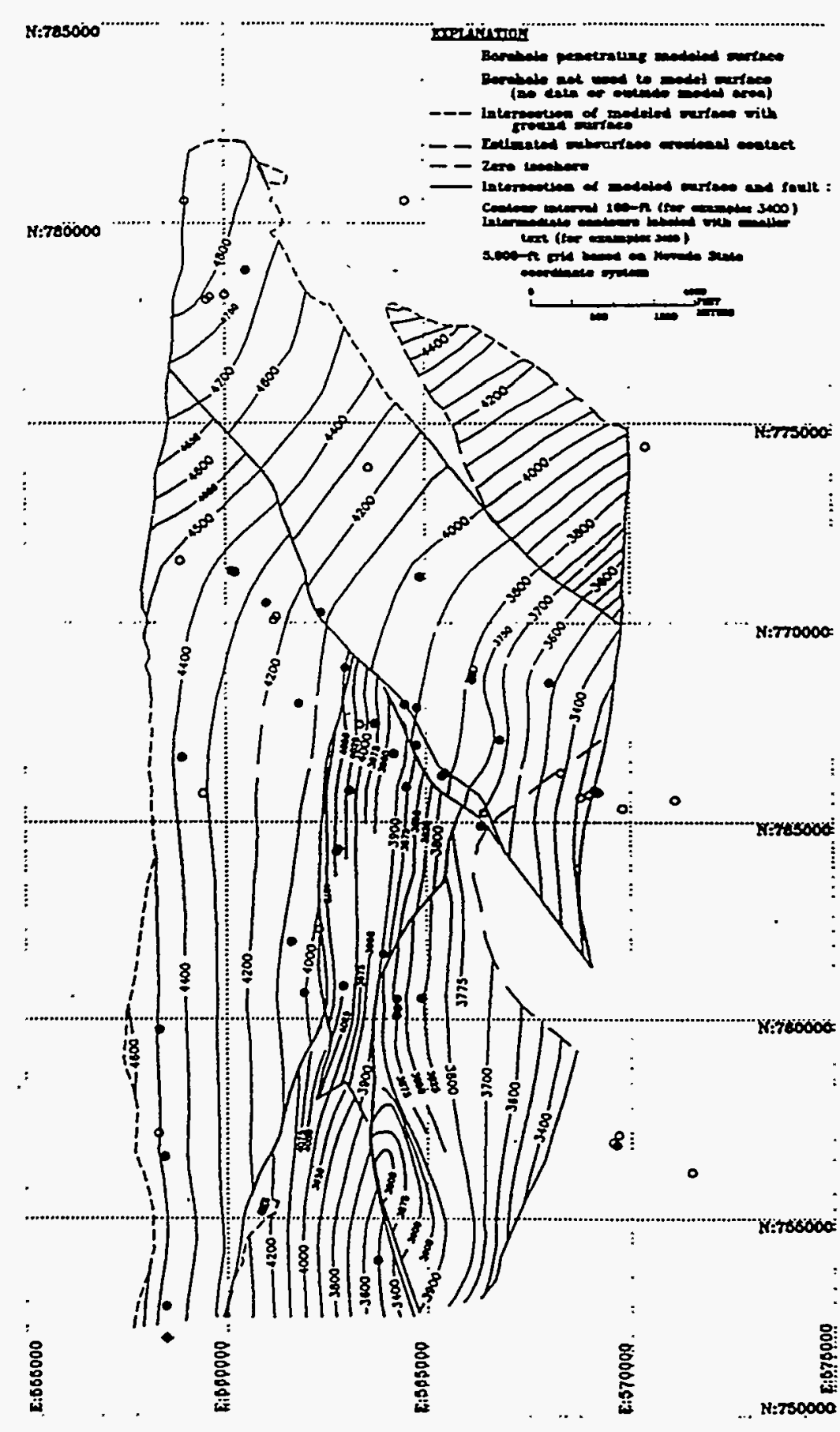

Appendix 5c. Structure contour map of the base of the model pre-Tiva Canyon Tuff bedded tuff and Yucca Mountain Tuff unit (Tpy). 


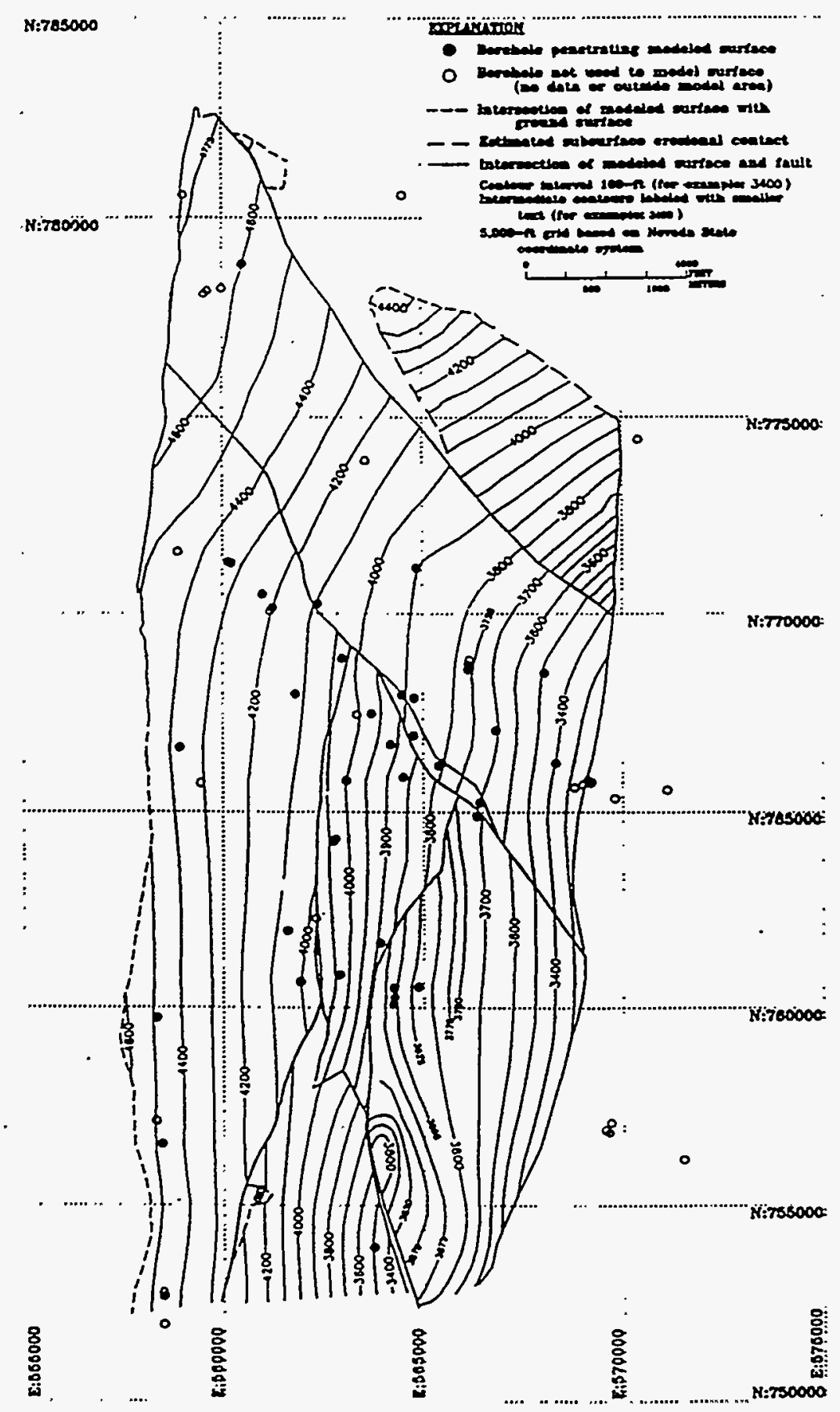

Appendix 5d. Structure contour map of the base of the model pre-Yucca Mountain Tuff bedded tuff unit (Tpbt3). 


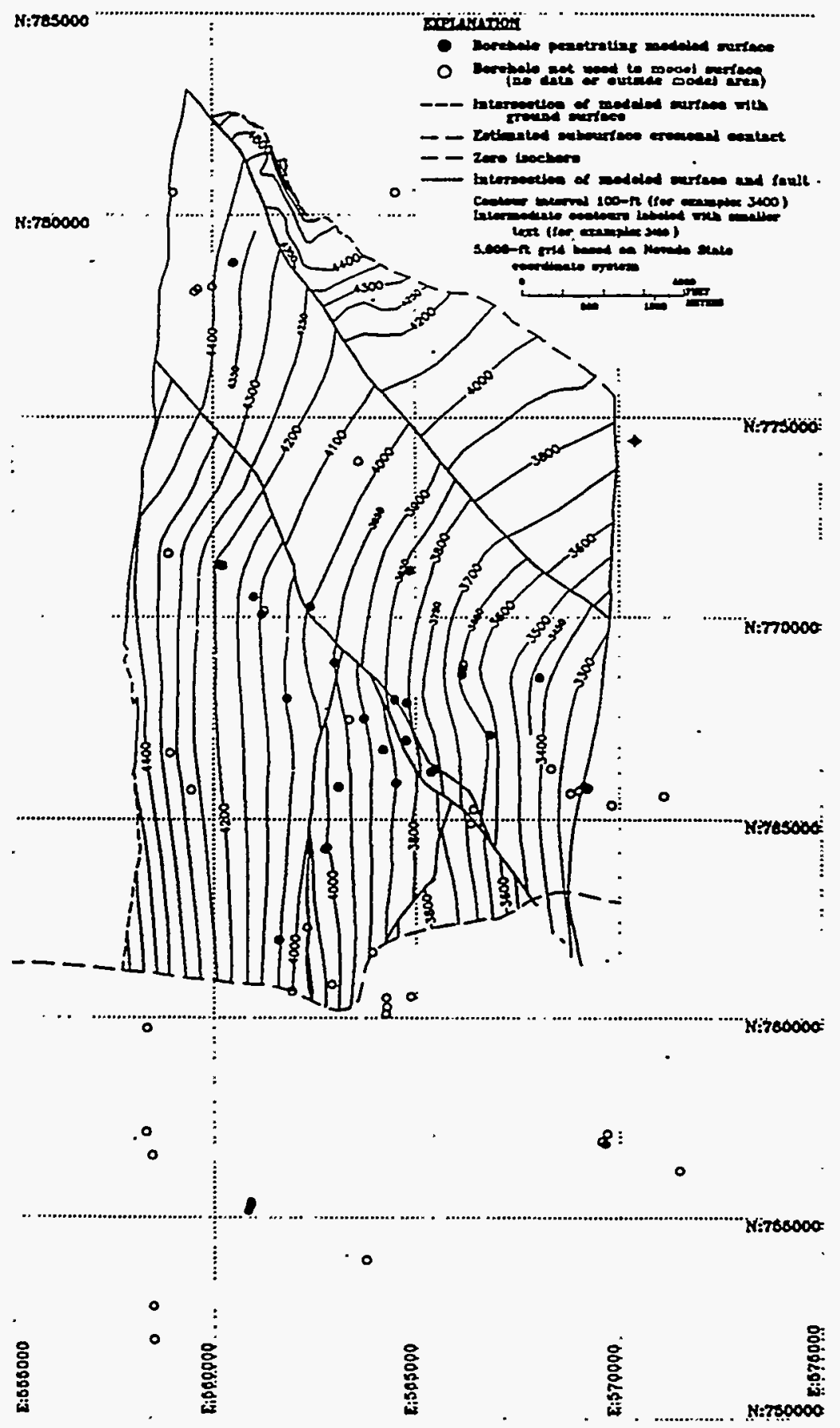

Appendix 5e. Structure contour map of the base of the model Pah Canyon Tuff unit (Tpp). 


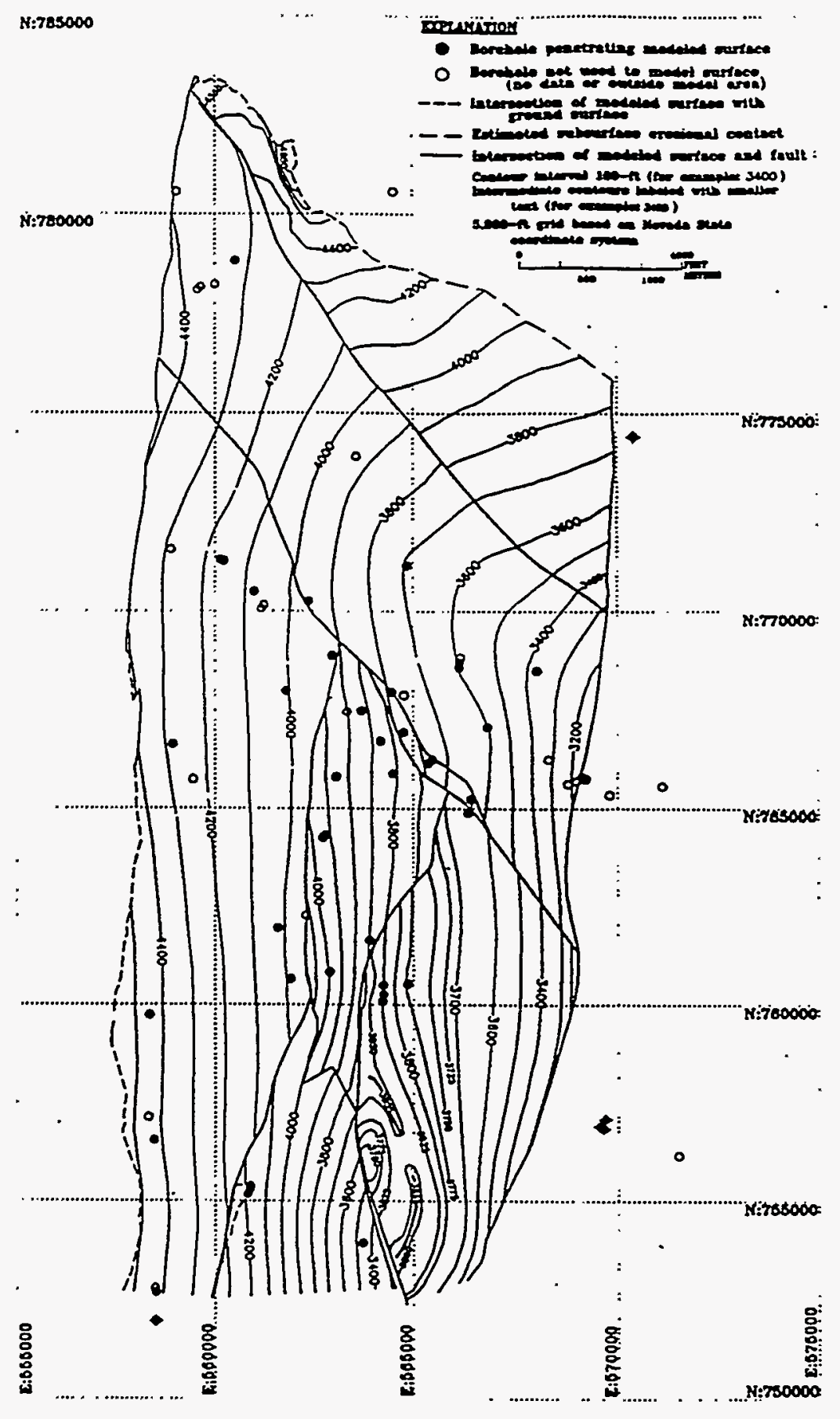

Appendix 5f. Structure contour map of the base of the model Topopah Spring Tuff crystal-rich nonwelded to moderately welded vitric unit (Tptrv). 


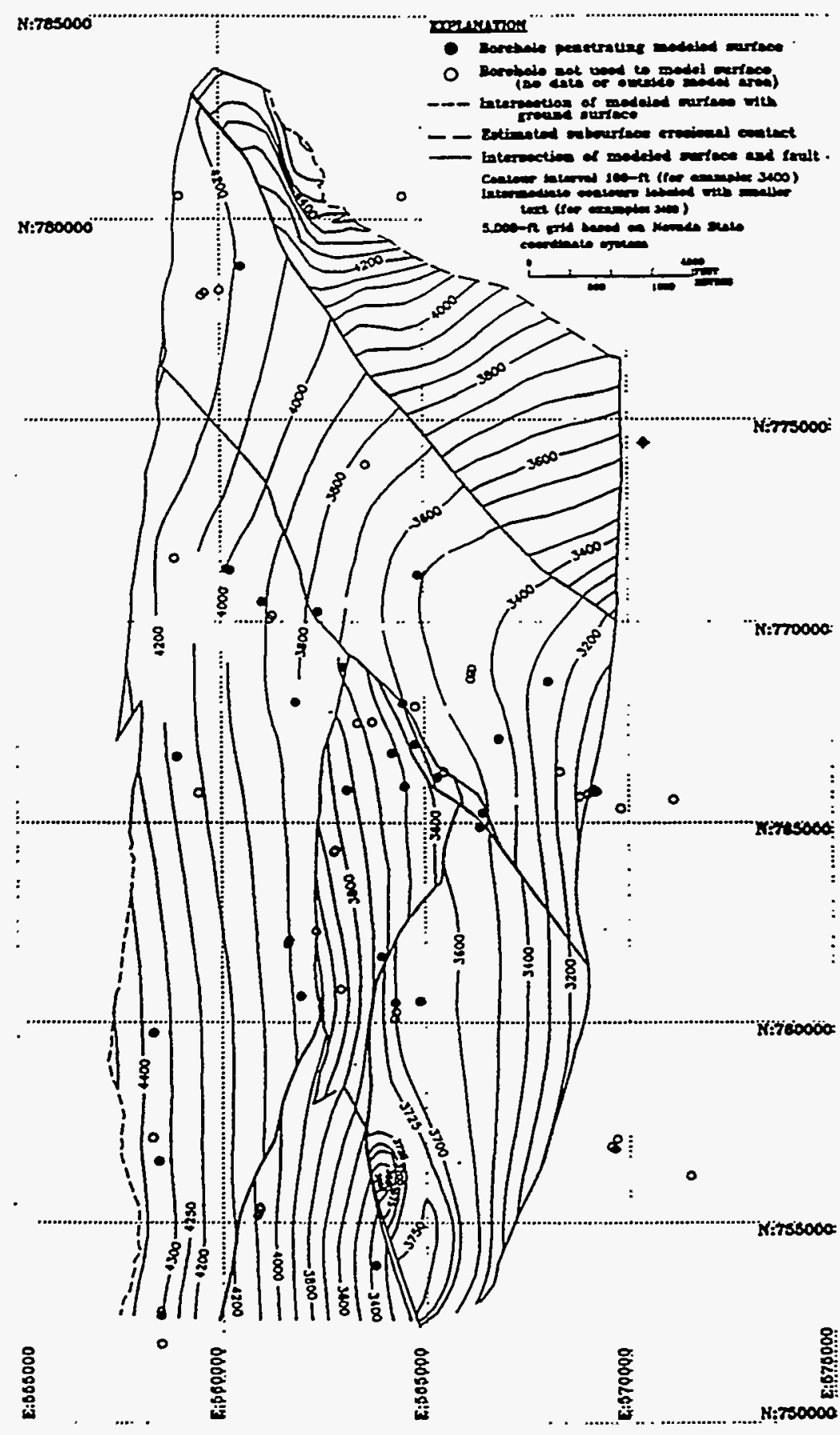

Appendix 5g. Structure contour map of the base of the model Topopah Spring Tuff crystal-rich nonlithophysal unit (Tptrn). 


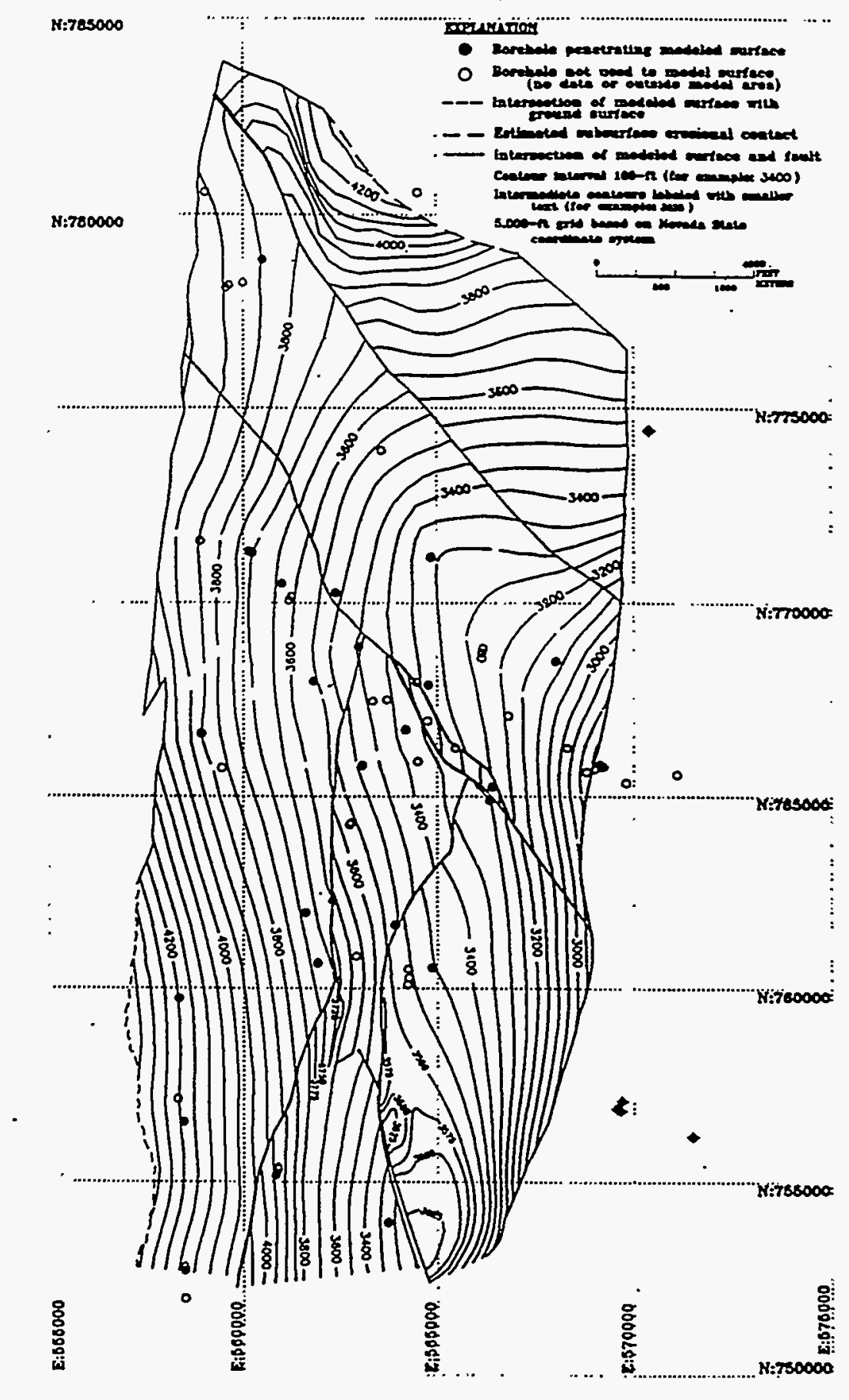

Appendix 5h. Structure contour map of the base of the model Topopah Spring Tuff upper lithophysal unit (Tptpul). 


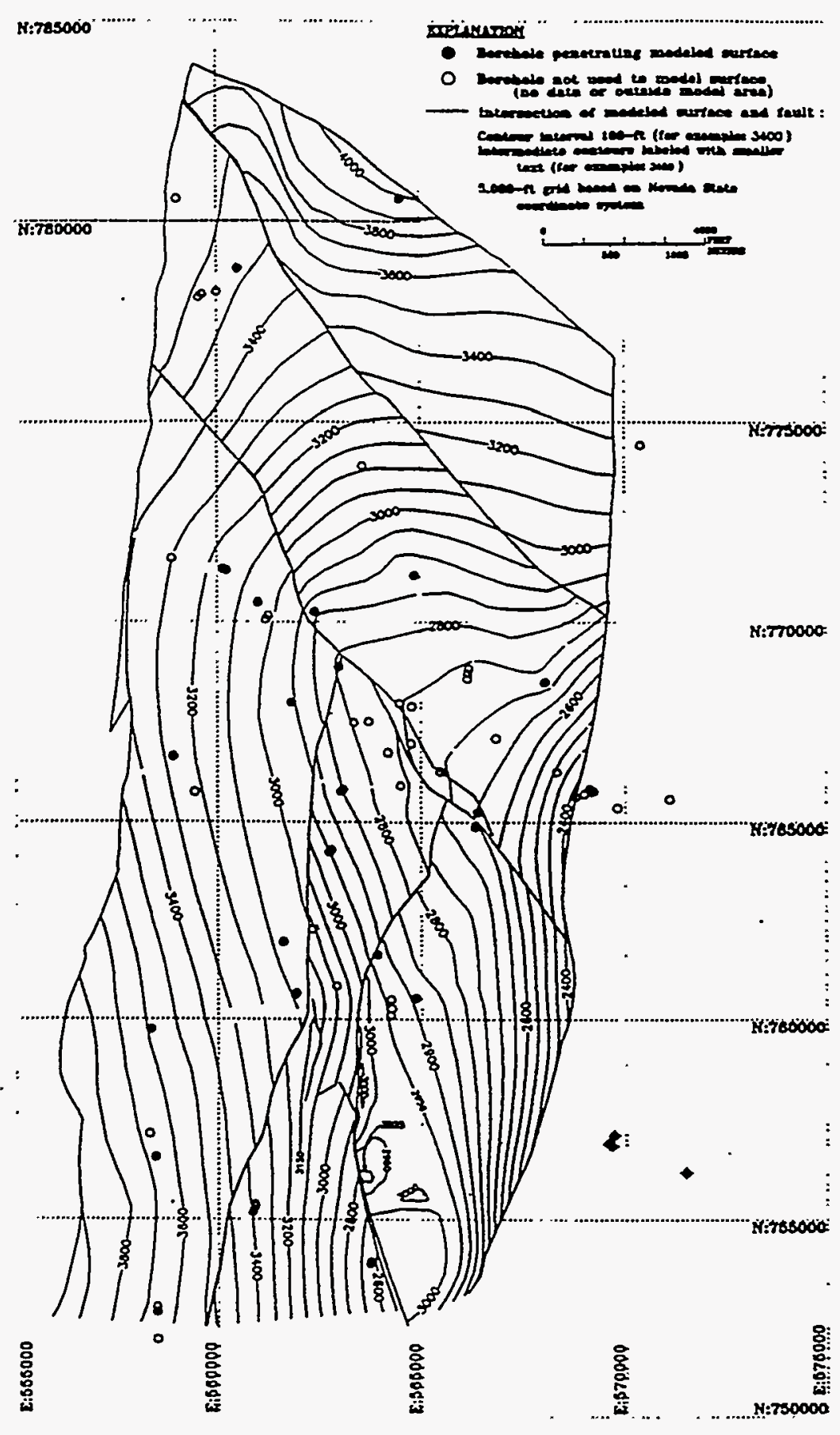

Appendix 5i. Structure contour map of the base of the model Topopah Spring Tuff lower nonlithophysal unit (Tptpln). 


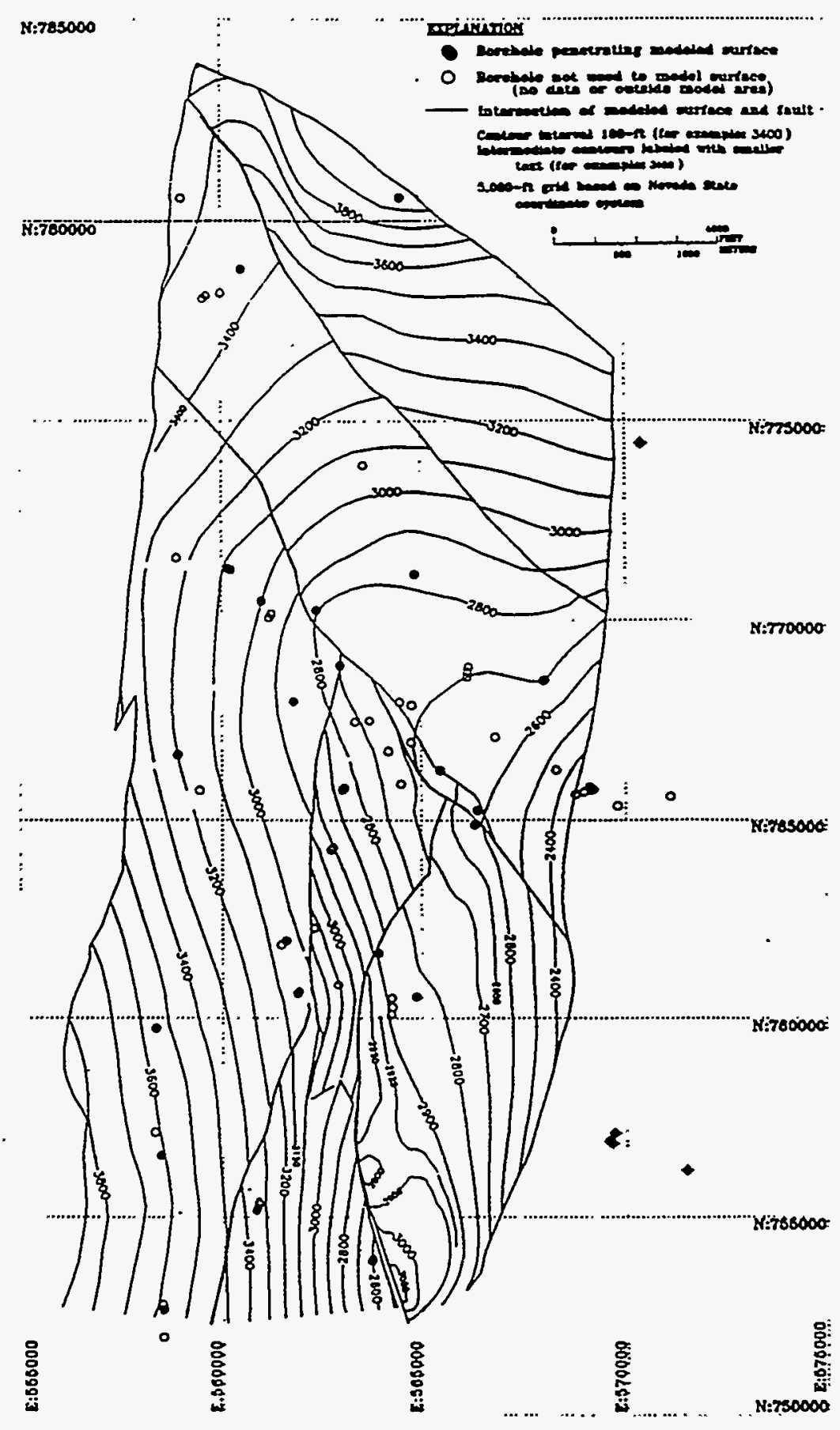

Appendix 5j. Structure contour map of the base of the model Topopah Spring Tuff crystal-poor densely welded vitrophyre unit (Tptpv3). 


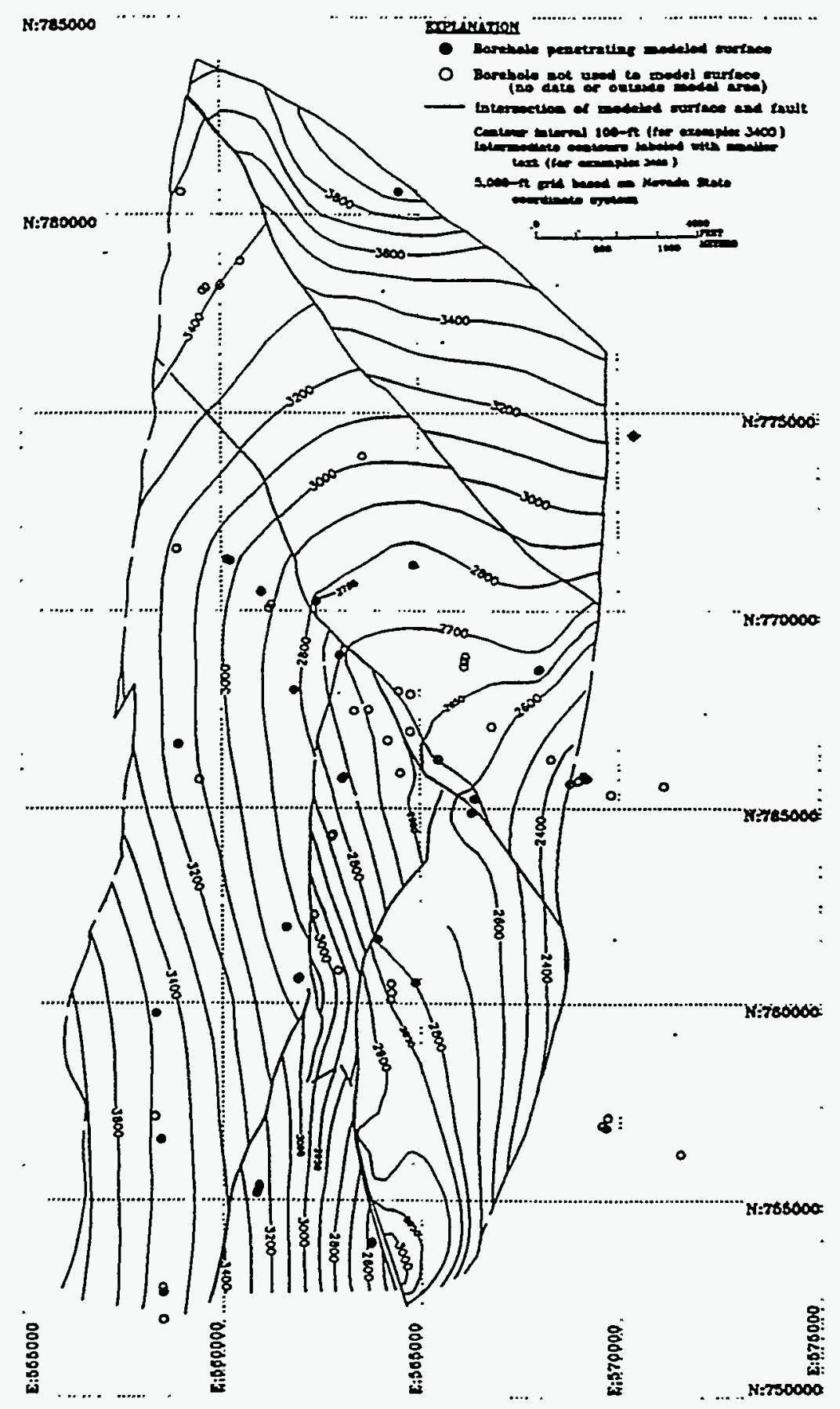

Appendix 5k. Structure contour map of the base of the model Topopah Spring Tuff crystal-poor nonwelded to moderately welded vitric unit (Tptpv1+2). 


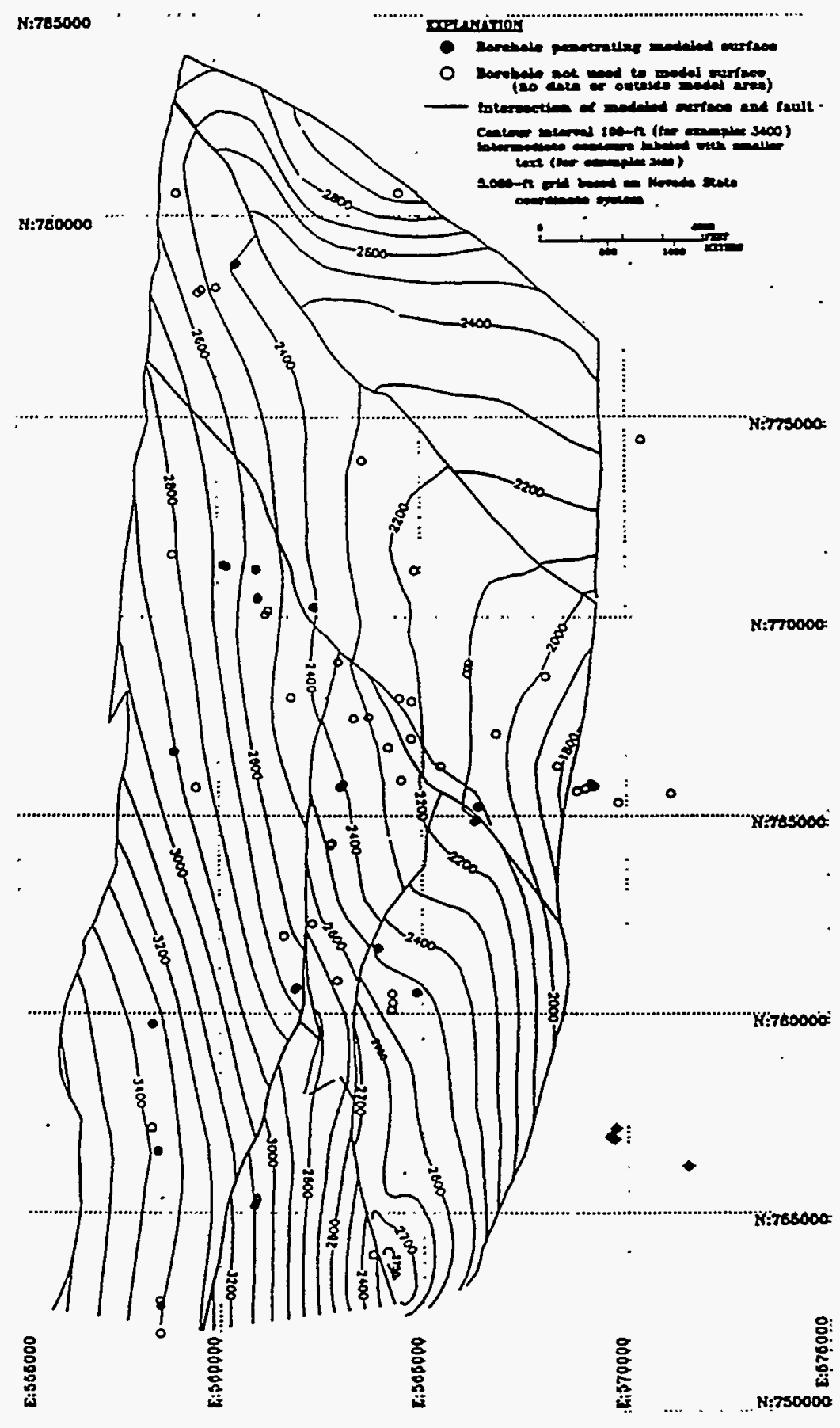

Appendix 51. Structure contour map of the base of the model Calico Hills Formation unit (Tac). 


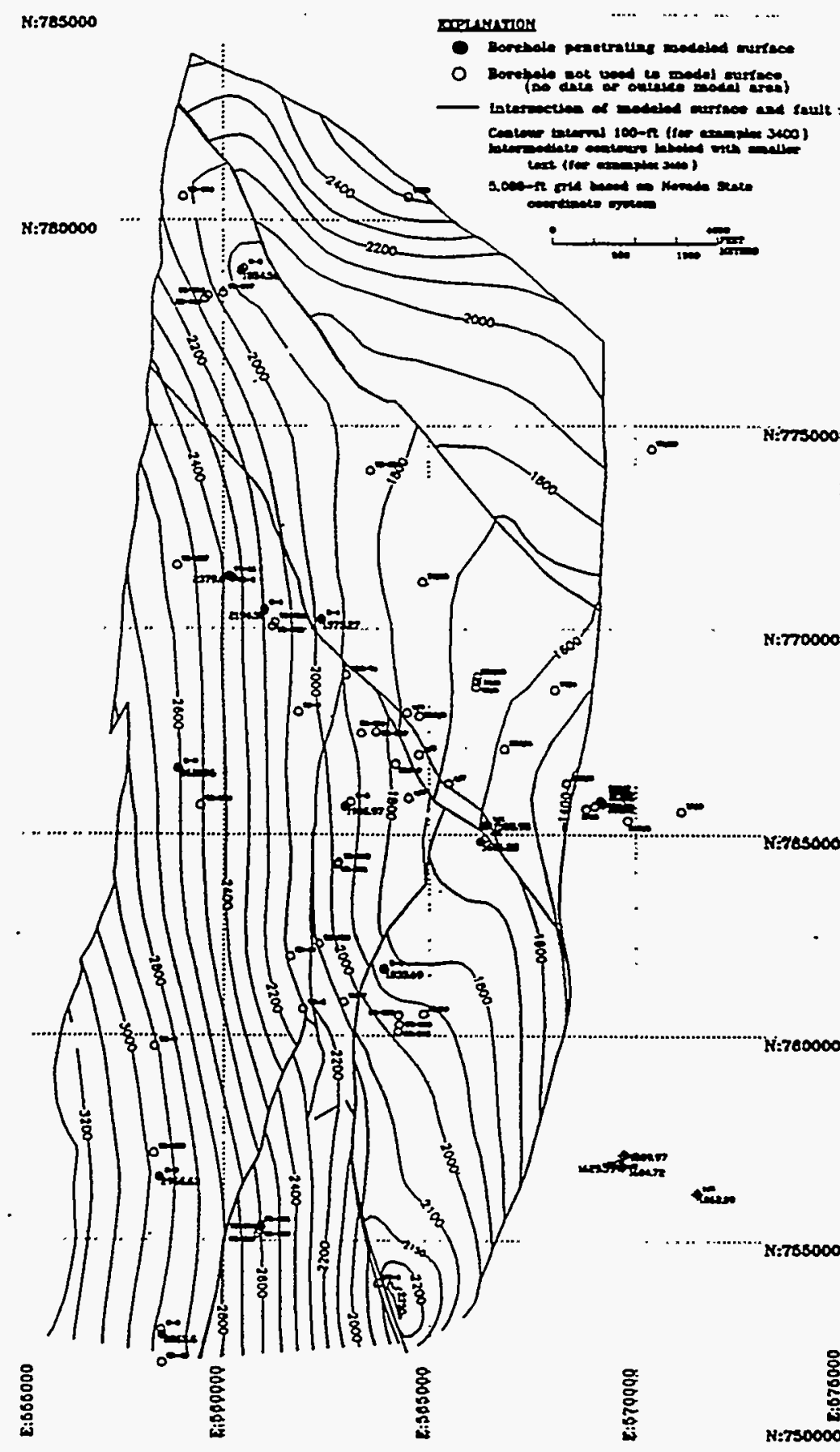

Appendix 5m. Structure contour map of the base of the model Prow Pass Tuff unit (Tcp). 
The distribution code for this report is UC-814. 